\title{
Scenarioanalyse van het regionale aanbod van gediplomeerden van bètatechnische opleidingen
}

Citation for published version (APA):

Cörvers, F., \& van Thor, J. A. F. (2012). Scenarioanalyse van het regionale aanbod van gediplomeerden van bètatechnische opleidingen. ROA. ROA Technical Reports No. 001 https://doi.org/10.26481/umarot.2012001

Document status and date:

Published: 01/01/2012

DOI:

10.26481/umarot.2012001

Document Version:

Publisher's PDF, also known as Version of record

\section{Please check the document version of this publication:}

- A submitted manuscript is the version of the article upon submission and before peer-review. There can be important differences between the submitted version and the official published version of record.

People interested in the research are advised to contact the author for the final version of the publication, or visit the DOI to the publisher's website.

- The final author version and the galley proof are versions of the publication after peer review.

- The final published version features the final layout of the paper including the volume, issue and page numbers.

Link to publication

\footnotetext{
General rights rights.

- You may freely distribute the URL identifying the publication in the public portal. please follow below link for the End User Agreement:

www.umlib.nl/taverne-license

Take down policy

If you believe that this document breaches copyright please contact us at:

repository@maastrichtuniversity.nl

providing details and we will investigate your claim.
}

Copyright and moral rights for the publications made accessible in the public portal are retained by the authors and/or other copyright owners and it is a condition of accessing publications that users recognise and abide by the legal requirements associated with these

- Users may download and print one copy of any publication from the public portal for the purpose of private study or research.

- You may not further distribute the material or use it for any profit-making activity or commercial gain

If the publication is distributed under the terms of Article $25 \mathrm{fa}$ of the Dutch Copyright Act, indicated by the "Taverne" license above, 
1) Maastricht University

Research Centre for Education and the Labour Market | ROA

\section{Scenarioanalyse van het regionale aanbod van gediplomeerden van bètatechnische opleidingen}

Frank Cörvers

Jesper van Thor

\section{ROA Technical Report}

ROA-TR-2012/1

Research Centre for Education and the Labour Market Maastricht University

P.O. Box 616, 6200 MD Maastricht, The Netherlands

$\mathrm{T}+31433883647 \mathrm{~F}+31433884914$

secretary-roa-sbe@maastrichtuniversity.n www.roa.nl 


\title{
Scenarioanalyse van het regionale aanbod van gediplomeerden van bètatechnische opleidingen
}

\author{
Frank Cörvers \\ Jesper van Thor
}

ROA-TR-2012/1

oktober 2012

Research Centre for Education and the Labour Market Maastricht University

P.O. Box 616, 6200 MD Maastricht, The Netherlands

$\mathrm{T}+31433883647 \mathrm{~F}+31433884914$

secretary-roa-sbe@maastrichtuniversity.nl www.roa.nl 


\section{Scenarioanalyse: resultaten en voorbeeldsimulaties}

\subsection{Inleiding}

Het Platform Bèta Techniek heeft behoefte aan een scenarioanalyse met betrekking tot het regionale aanbod van gediplomeerden van technische opleidingen. Input voor deze studie zijn de gegevens zoals deze bij het CFI en CBS beschikbaar zijn op grond van de oktobertellingen van leerlingen en gediplomeerden, de demografische ontwikkelingen per regio alsmede de nationale prognoses in de Referentieramingen van het Ministerie van OCW. Er wordt in deze studie uitgegaan van de gediplomeerden van het mbo, hbo en wo.

De belangstelling voor deze scenarioanalyse is in eerste instantie ingegeven door de grote verwachte tekorten aan technisch opgeleiden (ROA, 2007). Deze tekorten doen zich echter in verschillende mate voelen in de diverse regio's van Nederland (zie bijv. Cörvers et al., 2005). Derhalve zijn werkgevers in de regio’s geïnteresseerd in het potentieel aan technisch opgeleiden dat zij in de toekomst kunnen verwachten. Uiteraard wordt dit toekomstig potentieel in belangrijke mate bepaald door de regionale bevolkingsontwikkeling. Daarnaast speelt de keuze voor een technische opleiding een rol. In het bijzonder onder vrouwen en allochtonen wordt nog weinig voor een technische opleiding gekozen. Eén van de vragen die in deze scenarioanalyse wordt beantwoord is in welke mate het totale aantal (bèta)technisch opgeleiden in een provincie kan worden vergroot als meer vrouwen en allochtonen voor een (bèta)technische opleiding kiezen (zie ook Cörvers, 2007).

Voor het uitvoeren van de scenarioanalyse is het van belang om zicht te hebben op het huidige aantal gediplomeerden in technische en niet-technische opleidingen. De aantallen gediplomeerden per provincie in het basisjaar zijn het startpunt voor de prognoses van de gediplomeerden per provincie, welke zijn samengesteld volgens de zogenaamde 'participatieratio'-methode. In deze methode wordt in beginsel uitgegaan van een vaste verhouding tussen het aantal gediplomeerden per provincie en de bevolking. De vaste verhoudingen in het basisjaar zijn berekend voor de verschillende bevolkingsgroepen in de regio's wat betreft leeftijd, geslacht en herkomst. Tevens is er in het basisscenario uitgegaan van een landelijke groei (of afname) van de verhouding tussen gediplomeerden van het mbo, hbo of wo en de betreffende bevolkingsgroep. In bijlage I van dit rapport wordt uitgebreid stilgestaan bij de gebruikte data en de gevolgde methodiek.

Vanwege het grote belang van de bevolkingsprognoses voor het toekomstige aantal gediplomeerden per provincie, wordt er in hoofdstuk 2 apart ingegaan op de regionale bevolkingsprognoses van het CBS. De prognoses van het aantal 15 tot 30-jarigen zijn van belang om de toekomstige ontwikkeling van het aantal gediplomeerden met een bètatechnische opleiding per provincie te bepalen. De omvang van de totale groep 15 tot 30-jarigen in Nederland neemt toe tot en met 2020. Er wordt een stijging van deze groep voorzien van iets meer dan 5,5 \%-punt. Na 2020 daalt de omvang van deze groep weer enigszins. In 2025 laten de prognoses voor de groep 15 tot 30-jarigen in Nederland een toename van 3,6 \%-punt zien ten opzichte van 2008. Flevoland en Noord-Holland zijn de provincies waarvoor de meeste groei te verwachten is in de omvang van de groep 15 tot 30-jarigen. Limburg laat na een aanvankelijke lichte stijging van het aantal personen in de leeftijdscategorie 15 tot 30-jarigen een sterke daling zien met bijna 11 \%-punt in 2025 ten opzichte van 2008. Ook Groningen, Friesland en Noord-Brabant laten per saldo een afname zien over deze periode, hoewel in veel geringere mate.

Uit het eerder genoemde basisscenario van het aantal gediplomeerden en de hierboven genoemde bevolkingsprognoses volgen de gemiddelde aandelen gediplomeerden met een bètatechnische opleiding van het mbo, hbo en wo. In paragraaf 1.2 wordt de ontwikkeling van deze aandelen tussen 2008 en 2025 geïllustreerd. Er zal blijken dat de aandelen redelijk constant blijven, omdat in het basisscenario de deelname aan techniek van de verschillende groepen wat betreft leeftijd, geslacht en herkomst slechts geleidelijk en trendmatig verandert. Hoewel er grote verschillen zijn wat betreft de deelname aan bètatechniek tussen deze groepen, bijvoorbeeld mannen volgen vaker een bètatechnische opleiding dan vrouwen, verandert de bevolkingssamenstelling niet zo sterk, waardoor de verandering in de bevolkingssamenstelling een geringe invloed heeft op het gemiddelde 
aandeel gediplomeerden dat met een bètatechnisch diploma het mbo, hbo of wo verlaat.

Hoewel de gemiddelde aandelen gediplomeerden met een technisch diploma over het algemeen redelijk stabiel blijven, geldt dat niet voor het aantal gediplomeerden met een bètatechnisch diploma in de verschillende provincies. Deze aantallen worden immers sterk gedreven door de regionale bevolkingsprognoses, welke ook sterk verschillen tussen provincies. In hoofdstuk 3 wordt ingegaan op de ontwikkeling van het aantal gediplomeerden bètatechniek voor Nederland en de verschillende provincies, waarbij ook gedifferentieerd wordt naar geslacht en herkomst. ${ }^{1}$ Er zal blijken dat in Noord-Holland, Flevoland en Utrecht een behoorlijke stijging wordt verwacht van de totale groep afgestudeerden mbo techniek. Limburg laat daarentegen een daling zien van bijna 15 \%-punt in dezelfde periode. Voor Groningen, Friesland, Gelderland, Zeeland en Noord-Brabant worden afnames voorzien van minder dan 5 \%-punt in 2025 . De prognoses van het aantal mbo-gediplomeerden techniek voor Nederland als geheel laten een lichte stijging zien, gevolgd door een lichte daling. Tussen 2008 en 2025 komt de toename van het aantal afgestudeerden mbo techniek in Nederland nauwelijks boven de 3 \%-punt uit. Ook het totale aantal afgestudeerde personen met een afgeronde technische hbo-opleiding kan sterk verschillen tussen provincies. Flevoland en Noord-Holland laten sterke stijgingen zien, terwijl er in 2025 vooral in Limburg maar ook in Groningen en Friesland minder afgestudeerde hbo-technici verwacht worden dan in 2008 . Voor Nederland als geheel neemt het aantal gediplomeerden hbo techniek toe met bijna 6 \%-punt. De prognoses voor de ontwikkeling van het totale aantal gediplomeerden wo techniek in Nederland laten een gestage toename zien van deze groep tot bijna 9 \%-punt tussen 2008 en 2025. Groningen en vooral Limburg zijn de enige provincies waarin het aantal gediplomeerden wo techniek naar verwachting lager zal zijn in 2025 dan in 2008.

Om een eventuele terugval van het aantal gediplomeerden in techniek tegen te gaan, kan er worden ingezet op het stimuleren van de keuze voor bètatechniek onder bepaalde groepen waarin bètatechniek is ondervertegenwoordigd, zoals onder vrouwen en allochtonen. In paragraaf 1.3 wordt geïllustreerd wat het resultaat is als er extra groei van het aandeel gediplomeerden techniek zou zijn onder deze groepen binnen mbo, hbo en wo. Er worden zes verschillende groepen onderscheiden waarvoor het aandeel techniek kan verschillen: vrouwelijke autochtonen, vrouwelijke westerse allochtonen, vrouwelijke niet-westerse allochtonen, mannelijke autochtonen, mannelijke westerse allochtonen en tot slot mannelijke niet-westerse allochtonen. In het algemeen kan gesteld worden dat het met name de mannelijke autochtonen zijn die voor een technische opleiding kiezen. Aangezien het aandeel techniek onder allochtonen en vrouwen achterblijft, is het beleid er voornamelijk op gericht om het aandeel techniek onder deze groepen te verhogen. In een scenarioanalyse kan het aandeel techniek naar geslacht en herkomst dus als belangrijke stuurvariabele fungeren, zeker voor regio's waarin het aantal gediplomeerden met een technisch diploma dramatisch terugloopt.

De bedoeling van de scenarioanalyse in paragraaf 1.3 is dat de lezer zelf de bij dit rapport horende Excel-tool naar believen kan gebruiken. Zo is het mogelijk om een 'target' te definiëren wat betreft het gemiddelde aandeel gediplomeerden met een bètatechnisch diploma in een provincie in een bepaald jaar (tot 2025) en vervolgens na te gaan hoe groot de groei moet zijn in de verschillende bevolkingsgroepen (naar geslacht en herkomst) om de target te realiseren.

Het rapport is als volgt opgebouwd. Het eerste hoofdstuk bevat de belangrijkste resultaten en gebruiksmogelijkheden van het onderzoek. In paragraaf 1.2 wordt het gemiddelde aandeel techniek per provincie besproken voor achtereenvolgens mbo, hbo en wo in de periode 2008-2025. Het gaat hierbij om het aandeel techniek in het basisscenario. In paragraaf 1.3 worden vervolgens drie voorbeelden gegeven van simulaties met de bijbehorende Excel-tool. Er wordt geïllustreerd wat de verwachte toename van het aantal gediplomeerden (bèta)techniek zou zijn, indien er meer allochtonen en vrouwen voor techniek zouden kiezen.

1. Bijlage II bevat bovendien alle figuren die niet expliciet in hoofdstuk 3 aan de orde komen. 
De hoofdstukken 2 en 3 en de bijlagen zijn bedoeld voor de lezers die meer achtergrondinformatie willen hebben over de gebruikte gegevens en de methodologie. Hoofdstuk 2 schetst in het kort de bevolkingsontwikkeling naar regio, terwijl hoofdstuk 3 weergeeft hoe het toekomstige aanbod van (bèta)technisch opgeleiden zich volgens het basisscenario ontwikkelt tot 2025 voor respectievelijk mbo, hbo en wo. Van belang zijn voorts nog de bijlagen. In bijlage I wordt uitgebreid ingegaan op de gebruikte data en de methodiek. Bijlage II toont de figuren voor de prognoses van het aantal afgestudeerden techniek per opleidingsniveau, gedifferentieerd naar geslacht en herkomst van 2008 tot 2025. Tot slot vestigen we graag de aandacht op de interactieve module voor scenarioanalyses die bij dit rapport hoort. Deze Excel-tool wordt door het Platform op zijn website ter beschikking gesteld.

\subsection{Gemiddeld aandeel techniek per provincie}

Deze paragraaf geeft de prognoses weer voor het gemiddelde aandeel afgestudeerden techniek per provincie voor de periode 2008-2025 in het basisscenario. De resultaten worden achtereenvolgens per opleidingsniveau (mbo, hbo en wo) besproken. Het aantal gediplomeerden in de bètatechnische richting hangt af van zowel het aandeel jongeren in een leeftijdsklasse dat een mbo-, hbo- of wo-diploma haalt, als het aandeel jongeren, gedifferentieerd naar geslacht en herkomst, dat afstudeert in een bètatechnische richting.

\section{Mbo-gediplomeerden}

Figuur 1.1 geeft de prognoses weer voor het gemiddelde aandeel gediplomeerden mbo techniek ten opzichte van het totale aantal mbo-gediplomeerden tot 2025. Zoals blijkt uit deze figuur blijft het gemiddelde aandeel techniek in het algemeen vrij constant gedurende de hele periode. Voor Nederland als geheel geldt dat het aandeel techniek voor personen met een mbo-opleiding iets boven de 27\% ligt tussen 2008 en 2025. Dit betekent in de praktijk dat bijna drie op de tien personen die een mbo-diploma haalt een technische opleiding gevolgd heeft. Van alle afzonderlijke provincies is het aandeel mbo techniek in Zeeland met om en nabij de $34 \%$ het hoogst. Ook Noord-Brabant scoort relatief hoog met een aandeel mbo techniek van bijna 31\%. De provincie met het laagste aandeel mbo techniek is Flevoland. Tussen 2008 en 2025 schommelt het aandeel mbo techniek in deze provincie rond de $23 \%$. 
Figuur 1.1

Aandeel gediplomeerden mbo techniek als percentage van het totaal aantal mbo-gediplomeerden, 2008-2025

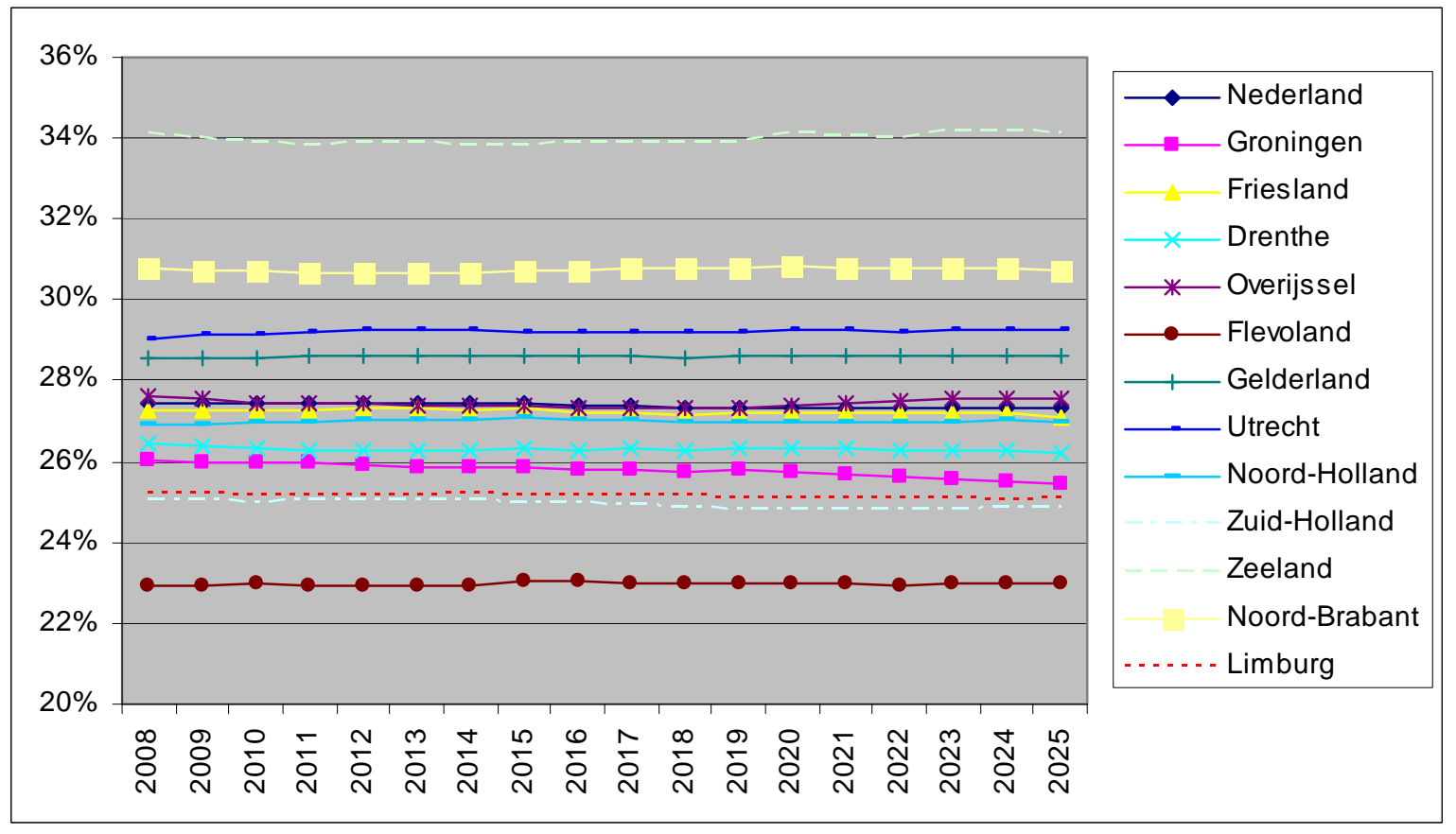

\section{Hbo-gediplomeerden}

Figuur 1.2 geeft de prognoses weer voor het gemiddelde aandeel gediplomeerden hbo techniek ten opzichte van het totale aantal hbo-gediplomeerden voor de periode 2008-2025. In vergelijking met het landelijke aandeel mbo techniek, dat gedurende de hele periode iets meer dan $27 \%$ bedraagt, ligt het gemiddelde aandeel hbo techniek beduidend lager (circa 15,5\%). Wederom is Zeeland de provincie met het grootste aandeel techniek. Vergeleken met het basisjaar, neemt dit aandeel echter enigszins af (-0,7 \%-punt). Opvallend is dat Zeeland, de provincie met het grootste aandeel gediplomeerden hbo techniek (ongeveer 20\%), een lager aandeel heeft dan de provincie met het laagste aandeel gediplomeerden bij mbo techniek in figuur 1.1, Flevoland (23\%). 
Figuur 1.2

Aandeel gediplomeerden hbo techniek als percentage van het totaal aantal hbo-gediplomeerden, 2008-2025

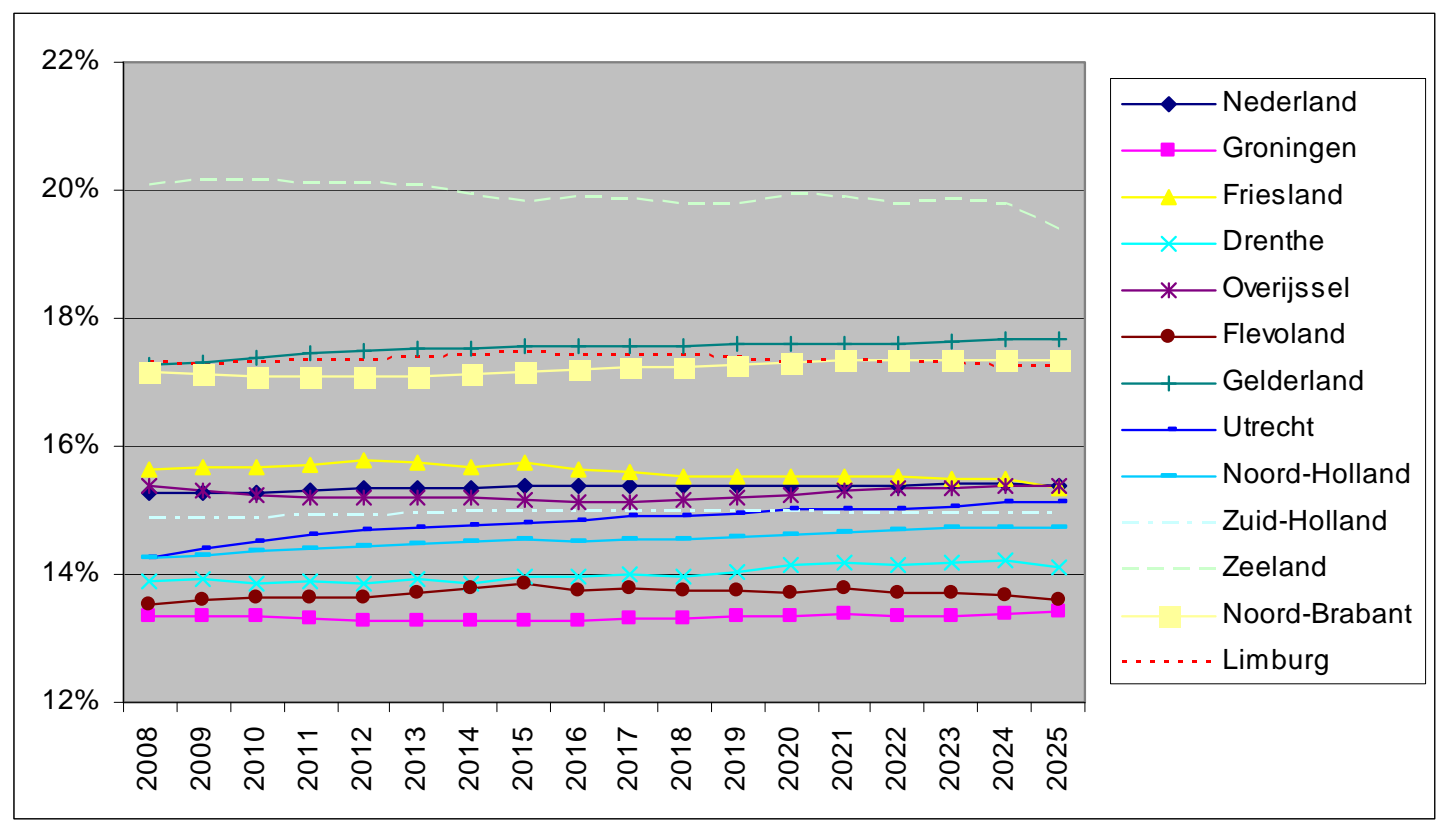

\section{Wo-gediplomeerden}

Figuur 1.3 geeft de prognoses weer voor het gemiddelde aandeel gediplomeerden wo techniek ten opzichte van het totale aantal wo-gediplomeerden voor de periode 2008-2025. Het gemiddelde aandeel gediplomeerden wo techniek in Nederland (ruim 16\%) ligt op een vergelijkbaar niveau als het gemiddelde aandeel gediplomeerden hbo techniek en dus ook aanzienlijk lager dan het aandeel gediplomeerden mbo techniek. Meest in het oogspringend volgens de prognoses is dat een aanzienlijk deel van de wo-gediplomeerden in Overijssel een technische opleiding genoten heeft, namelijk circa 36\% gedurende de hele periode. Het aandeel gediplomeerden wo techniek in de overige provincies ligt beduidend lager. Van de overige provincies levert alleen Zuid-Holland, met een aandeel van ruim 23\%, meer dan één op de vijf wo-gediplomeerden met een technisch diploma. Limburg blijft met een aandeel wo techniek van circa 6\% het verst achter. 
Figuur 1.3

Aandeel gediplomeerden wo techniek als percentage van het totaal aantal wo-gediplomeerden, 2008-2025

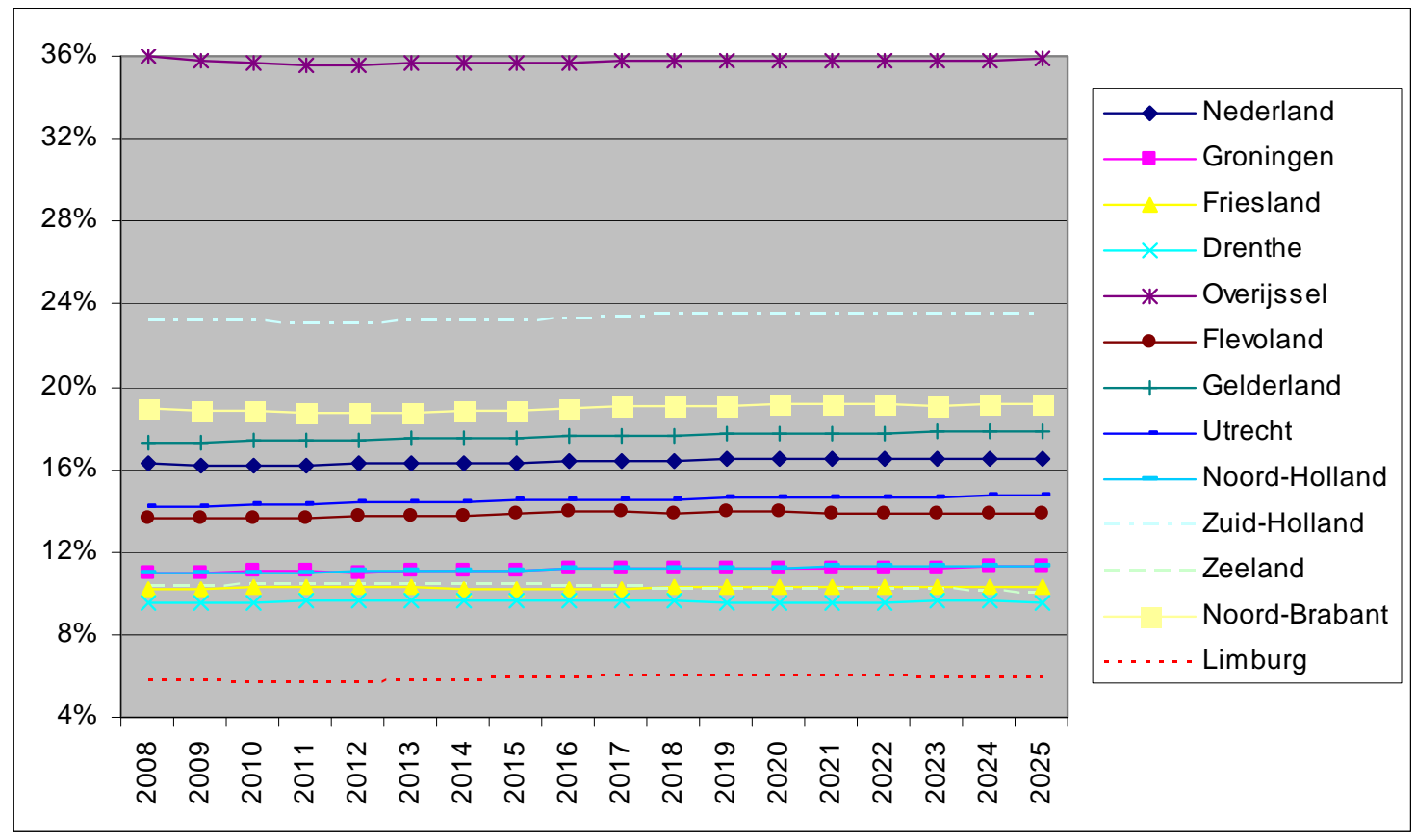

\subsection{Voorbeeldsimulaties}

In deze paragraaf worden drie voorbeelden gepresenteerd van mogelijke simulaties aan de hand van de bij dit rapport horende 'Excel-tool'. Deze voorbeelden dienen ter illustratie van de mogelijkheden van deze tool en als handleiding voor het gebruik ervan. Daartoe wordt stap voor stap de werking van de 'Excel-tool' uitgelegd. Nadat de gebruiker een concreet doel heeft bepaald (bijvoorbeeld een stijging van 10\% van het totale aantal gediplomeerden mbo techniek in provincie X na tien jaar), kan hij/zij met behulp van het bijbehorende Excelprogramma nagaan hoe deze verandering gerealiseerd kan worden. Dit kan door te 'spelen' met de eerder besproken stuurvariabelen geslacht en herkomst. Achtereenvolgens zullen drie voorbeelden van mogelijke simulaties gepresenteerd worden. Deze hebben betrekking op respectievelijk Nederland, Zuid-Holland en NoordBrabant.

\section{Simulatie 1: Nederland}

In het eerste voorbeeld simuleren we een scenario voor een toename van het totale aantal gediplomeerden mbo techniek voor geheel Nederland. Door te simuleren met het percentage techniek van de zes groepen verandert het gemiddelde percentage mbo techniek en zodoende kan achterhaald worden op welke wijze het absolute aantal gediplomeerden mbo techniek in Nederland beïnvloed wordt.

Stap 1

Alvorens daadwerkelijk met de Excel-tool te kunnen simuleren, dient er een doelstelling geformuleerd te worden. Stap 1 is dus het formuleren van een concrete doelstelling. De stappen die vervolgens genomen worden, zijn gericht op het realiseren van deze doelstelling. In deze eerste simulatie gaan we ervan uit dat:

'het totale aantal gediplomeerden mbo techniek in Nederland na vijf jaar met 5\% toegenomen moet zijn'. 
Stap 2

In stap 2 wordt het juiste Excel-bestand gekozen. Er dient daarbij een keuze voor het opleidingsniveau gemaakt te worden, dus voor mbo, hbo of wo (stap 2a). Uit de doelstelling blijkt dat we hier geïnteresseerd zijn in het aantal gediplomeerden $m b o$ techniek. Daarna volgt stap $2 b$. Hierin kiezen we voor een bepaald geografische gebied, zoals in de doelstelling geformuleerd. Tijdens deze stap dient de gebruiker te kiezen voor een provincie of voor Nederland als totaal. Aangezien 'het totale aantal gediplomeerden mbo techniek in Nederland na vijf jaar met 5\% toegenomen moet zijn', kiezen we voor het bestand 'Nederland bevolking en geslaagden mbo'.

\section{Stap 3}

Nadat we het juiste Excel-bestand geopend hebben volgt stap 3. Ook stap 3 is gebaseerd op de eerder geformuleerde doelstelling: 'het totale aantal gediplomeerden mbo techniek in Nederland moet na vijf jaar met $5 \%$ toegenomen zijn'. Dit betekent dat we in het bestand 'Nederland bevolking en geslaagden mbo' kiezen voor het laatste tabblad ' $M B O \_N L \_M V$ ', omdat dit de prognoses weergeeft voor zowel de mannelijke alsook de vrouwelijke afgestudeerden mbo techniek in Nederland.

\section{Stap 4}

In stap 4 gaat het erom of we informatie willen verkrijgen over een absolute (totaal aantal) dan wel een relatieve (aandeel) verandering van de mbo gediplomeerden techniek. In ons voorbeeld gaat het om een absolute toename, waardoor we geïnteresseerd zijn in de waarden uit rij 12 'MBO techniek'. Hier zien we bijvoorbeeld in cel 'E12' dat de prognoses weergeven dat in de uitgangssituatie 39.725 personen een diploma mbo techniek behalen in 2008.

\section{Stap 5}

In stap 5 ligt de focus op het tijdselement van onze doelstelling. Wanneer we weer terugdenken aan onze doelstelling: 'het totale aantal gediplomeerden mbo techniek in Nederland moet na vijf jaar met $5 \%$ toegenomen zijn', dan zijn we in dit geval geïnteresseerd in de absolute waarde in het jaar 2013 (cel 'J12'). Uit onze doelstelling blijkt echter dat we een toename in dat jaar willen van $5 \%$ bovenop het aantal van 2008. Onze doelstelling is dus dat er 41.711 personen afstuderen met een mbo-diploma techniek in 2013. ${ }^{2}$

\section{Stap 6}

In stap 6 gaan we de Excel-tool als het ware laten 'terugrekenen' hoe dit gerealiseerd kan worden. Door het aanpassen van de stuurvariabelen in het 'Invoer' tabblad kunnen we zodoende achterhalen hoe het gewenste resultaat bereikt kan worden. In ons voorbeeld gaan we na wanneer er ten minste 41.711 personen een mbodiploma techniek behalen in 2013.

We veronderstellen dat deze groei met name gerealiseerd kan worden onder enerzijds westerse en niet-westerse allochtonen en anderzijds onder vrouwen, omdat het gemiddelde aandeel techniek onder deze groepen tot op heden het laagste is. In het invoerscherm laten we de jaarlijkse additionele groei van het aandeel techniek voor autochtone mannen op ' $0,0 \%$ ' staan en simuleren daarom met de overige variabelen.

Allereerst laten we het aandeel techniek voor westerse allochtone mannen jaarlijks met $1 \%$ toenemen en datzelfde aandeel voor niet-westerse allochtone mannen jaarlijks met $2 \%$ toenemen. Voor westerse en nietwesterse allochtone vrouwen laten we dit aandeel beide jaarlijks met $4 \%$ toenemen. Vervolgens kijken we naar het effect op het absolute aantal personen met een mbo-diploma in 2013. Het resultaat is terug te vinden in tabblad ' $M B O \_N L \_M V$ ', cel ' $J 12$ '. De door ons doorgevoerde veranderingen resulteren in een stijging van het totale aantal personen met een diploma mbo techniek. In totaal zijn er in de nieuwe situatie 41.699 gediplomeerden mbo techniek. Echter, we wilden een situatie creëren waarin tenminste 41.711 personen in 2013 afstuderen in mbo techniek. Daarom moeten we nog een kleine aanpassing in het invoerscherm doen, zodat deze

2. Berekening: $1,05 * 39.725=41.711$. 
groei van $5 \%$ ook daadwerkelijk gerealiseerd wordt. We veronderstellen dat de groep niet-westerse allochtone vrouwen mbo techniek het meest kan toenemen. Daarom verhogen we dit aandeel in het invoerscherm van 4 naar 4,5\%. Wanneer we vervolgens opnieuw in het tabblad ' $M B O \_N L \_M V$ ' kijken in cel ' $J 12$ ' kunnen we concluderen dat ons beoogd resultaat, een toename van $5 \%$ na vijf jaar, gerealiseerd is ( $\mathrm{N}=41.739)$.

\section{Simulatie 2: Zuid-Holland}

In het tweede voorbeeld simuleren we een scenario voor de provincie Zuid-Holland, waarbij het gaat om een toename van het aandeel vrouwelijke hbo-gediplomeerden techniek in het totale aantal vrouwelijke hbogediplomeerden in deze provincie.

Stap 1

Stap 1 is wederom het formuleren van een concrete doelstelling. In dit tweede voorbeeld is de doelstelling:

'het verdrievoudigen van het aandeel vrouwelijke gediplomeerden hbo-techniek in 2025 in Zuid-Holland'.

Net als in het eerste voorbeeld kan vervolgens met behulp van deze Excel-tool nagegaan worden op welke manieren dit eindresultaat gerealiseerd kan worden. Bij elke volgende stap die genomen wordt, blijft bovenstaande doelstelling als uitgangspunt fungeren.

Stap 2

In dit geval kiezen we daarom voor het opleidingsniveau 'HBO' (Stap 2a). Vervolgens kiezen we in stap 2b voor het bestand 'Zuid-Holland bevolking en geslaagden HBO bachelor', zodat de resultaten alleen betrekking hebben op gediplomeerden hbo techniek in de provincie Zuid-Holland.

\section{Stap 3}

In stap 3 wordt het juiste tabblad binnen dit bestand gekozen. Aangezien we geïnteresseerd zijn in het verdrievoudigen van het aandeel vrouwelijke gediplomeerden hbo techniek in 2025 in Zuid-Holland, kiezen we voor het tabblad 'HBO_ZH_V', dat zich beperkt tot de prognoses voor vrouwen.

Stap 4

Bij stap 4 aangekomen, bekijken we of een absolute of een relatieve verandering gewenst is. Ditmaal zijn we geïnteresseerd in het 'aandeel vrouwelijke gediplomeerden HBO techniek' waardoor we naar de gegevens in rij 11 moeten kijken. Zo kunnen we concluderen dat het aandeel vrouwelijke gediplomeerden hbo techniek 2,6\% bedraagt en constant blijft gedurende de hele periode 2008-2025.

\section{Stap 5}

Ook stap 5 is weer gebaseerd op de eerder geformuleerde doelstelling. We willen bekijken wat er moet gebeuren om het aandeel vrouwelijke gediplomeerden hbo techniek verdrievoudigd te krijgen in 2025. Bij de simulaties gaan we dus op zoek naar een aandeel vrouwen hbo techniek van $3 * 2,6 \%=7,8 \%$ in het jaar 2025 .

Stap 6

In stap 6 gaan we de Excel-tool wederom laten 'terugrekenen' hoe dit eindresultaat in 2025 bereikt kan worden. Hiervoor moeten we de jaarlijkse groei van dit aandeel invoeren in het tabblad 'Invoer'. In dit voorbeeld spreekt het voor zich dat we alleen veranderingen hoeven aan te brengen in de jaarlijkse groei van het aandeel hbo techniek voor vrouwelijke autochtonen, vrouwelijke westerse allochtonen en vrouwelijke niet-westerse allochtonen. We veronderstellen dat er voornamelijk nog groei zit in het aandeel westerse en niet-westerse allochtone vrouwen, vandaar dat we hier iets grotere waarden invullen dan bij het aandeel autochtone vrouwen. Na enig uitproberen vinden we dat bijvoorbeeld bij een verdeling in het invoerscherm van autochtone vrouwen (5,5\%), westerse allochtone vrouwen $(7,5 \%)$ en niet-westerse vrouwen $(7 \%)$ het gemiddelde aandeel vrouwen 
binnen hbo techniek in 20253 maal zo groot is als in 2008, respectievelijk 7,8\% in 2025 ten opzichte van 2,6\% in 2008.

\section{Simulatie 3: Noord-Brabant}

In het derde voorbeeld gaan we ervan uit dat het gemiddelde aandeel gediplomeerden wo techniek in de toekomst zal toenemen in de provincie Noord-Brabant.

Stap 1

Als startpunt formuleren we opnieuw een concrete doelstelling:

'Over vijf jaar moet het gemiddelde aandeel gediplomeerden wo techniek in Noord-Brabant 25\% bedragen'.

Met behulp van de Excel-tool gaan we weer simuleren op welke wijze dit gewenste eindresultaat gerealiseerd kan worden. We willen in eerste instantie weten hoeveel het aandeel gediplomeerden wo techniek onder mannelijke autochtonen jaarlijks moet stijgen om dit resultaat te verwezenlijken.

Daarnaast willen we bekijken hoe dit gemiddelde aandeel wo techniek van $25 \%$ bereikt kan worden, enkel door een verhoging van het aandeel vrouwelijke westerse allochtonen. Ook hier geldt weer dat bovenstaande doelstelling als uitgangspunt blijft fungeren bij elke volgende stap die genomen wordt.

Ten slotte kan een aandeel van 25\% natuurlijk ook bereikt worden door een combinatie van veranderingen in beide genoemde groepen. Hiervan wordt verderop in deze paragraaf alleen de einduitkomst gegeven zodat de gebruiker, geholpen door de eerder gegeven voorbeelden, zelf kan narekenen of hij eenzelfde uitkomst krijgt.

Stap 2

In stap 2 is het van belang om het juiste Excel-bestand te kiezen. Zoals blijkt uit onze doelstelling kiezen we in stap 2a ditmaal voor het opleidingsniveau 'wo'. Vervolgens kiezen we het geografische gebied (stap 2b). In stap 2b kiezen we in dit voorbeeld dus voor het bestand ' Noord-Brabant bevolking en geslaagden WO'.

Stap 3

Tijdens stap 3 bepalen we in welk tabblad uit desbetreffend bestand de prognoses staan voor de uitgangssituatie. Aangezien we geïnteresseerd zijn in het aandeel mannelijke autochtone gediplomeerden wo techniek, kiezen we voor het tabblad 'WO_NB_M', dat alleen de prognoses voor mannen weergeeft.

In het tweede scenario zijn we geïnteresseerd in het aandeel techniek onder vrouwelijke westerse allochtonen en maken we dus gebruik van het tabblad 'WO_NB_V'.

Stap 4

Aangezien onze doelstelling in het eerste voorbeeld betrekking heeft op het aandeel mannelijke autochtone gediplomeerden wo techniek, moeten we nu kijken naar rij 83 van genoemd tabblad. Zo kunnen we concluderen dat het aandeel mannelijke autochtone gediplomeerden wo techniek in de uitgangsfase 29,7\% bedraagt in 2008 en een geringe stijging laat zien tot 2025.

In het tweede scenario bekijken we hoe het aandeel gediplomeerden wo techniek onder westerse allochtone vrouwen moet toenemen om een gemiddeld aandeel gediplomeerden wo techniek te bereiken van 25\%. In rij 97 van tabblad 'WO_NB_V', kunnen we nu teruglezen dat dit aandeel 5,7\% bedraagt in 2008.

Stap 5

We willen achterhalen wat er moet gebeuren om het gemiddelde aandeel gediplomeerden mbo techniek na 5 jaar (in 2013) op 25\% te laten uitkomen door te simuleren met het aandeel mannelijke autochtone gediplomeerden wo techniek. 
In het alternatieve scenario bekijken we wat er moet gebeuren om dit gemiddeld aandeel gediplomeerden wo techniek na 5 jaar (in 2013) op 25\% te laten uitkomen door te simuleren met het aandeel vrouwelijke westerse allochtone gediplomeerden wo techniek.

\section{Stap 6}

In stap 6 gaan we de Excel-tool wederom laten 'terugrekenen' hoe dit eindresultaat over 5 jaar gerealiseerd kan worden. Hiervoor voeren we in het tabblad 'Invoer' de jaarlijkse groei van dit aandeel in. In het eerste voorbeeld is het vanzelfsprekend dat we alleen veranderingen aanbrengen in de jaarlijkse groei van het aandeel gediplomeerden wo techniek voor mannelijke autochtonen. Hierdoor veronderstellen we dat er geen toe- of afname is van andere herkomstgroepen of personen van het andere geslacht. Na enig uitproberen in het invoerscherm vinden we dat door een jaarlijkse additionele groei van het aandeel techniek onder mannelijke autochtone wo-gediplomeerden van 6,7\%, het gemiddeld aandeel wo techniek in 2013 exact $25 \%$ bedraagt.

In het tweede scenario bekijken we hoe ditzelfde gemiddelde aandeel gediplomeerden wo techniek $25 \%$ bedraagt in 2013, nu echter door te achterhalen hoe het aandeel gediplomeerden wo techniek onder westerse allochtone vrouwen jaarlijks moet stijgen. Hier blijkt duidelijk dat het een stuk moeilijker is om eenzelfde resultaat, een gemiddeld aandeel techniek van 25\%, te bereiken. Jaarlijks moet het aandeel techniek onder westerse allochtone vrouwen met maar liefst 76\% stijgen om na vijf jaar een dergelijk gemiddeld aandeel te bereiken.

Ten slotte wijzen we nog op een mogelijk scenario waarin het gemiddelde aandeel wo techniek in 2013 25\% zal zijn door een combinatie van groei van het aandeel techniek in beide groepen. Hiervan wordt bewust alleen de einduitkomst gepresenteerd. De gebruiker kan zelf de zes stappen uit de voorgaande voorbeelden als hulpmiddel gebruiken. Het is bijvoorbeeld mogelijk om na vijf jaar een gemiddeld aandeel wo techniek te behalen door de combinatie van een jaarlijkse stijging van het aandeel techniek onder autochtone mannen van $5,4 \%$ en een jaarlijkse stijging van het aandeel techniek onder westerse allochtone vrouwen van $40 \%$. 


\section{Bevolkingsontwikkeling per provincie ${ }^{3}$}

Met betrekking tot het aantal gediplomeerden van mbo, hbo en wo is vooral de groep jongeren van 15 tot 30 jaar van belang. De regionale bevolkingsprognoses van deze leeftijdsgroep bepalen in belangrijke mate het verwachte aantal gediplomeerden per regio. Paragraaf 2.1 beschrijft daarom de regionale prognoses voor deze totale groep 15 tot 30-jarigen. In paragraaf 2.2 wordt deze groep uitgesplitst naar geslacht. Daarnaast is voor de ontwikkeling van het aantal gediplomeerden in bètatechniek het land van herkomst van belang. Derhalve wordt in paragraaf 2.3 de bevolkingsontwikkeling per provincie tot 2025 weergegeven voor de 15 tot 30-jarigen uitgesplitst naar herkomst. Om de provincies onderling en met Nederland als geheel te kunnen vergelijken worden indexcijfers voor de bevolkingsontwikkeling gebruikt. De gegevens zijn afkomstig van het CBS (Statline).

\subsection{Regionale bevolkingsprognose tot 2025}

In figuur 2.1 is de verwachte bevolkingsontwikkeling voor de totale groep 15 tot 30 -jarigen te zien. De omvang van de totale groep 15 tot 30-jarigen in Nederland neemt toe tot en met 2020. Er wordt een stijging van deze groep voorzien van iets meer dan 5,5 \%-punt. Na 2020 daalt de omvang van genoemde groep weer enigszins. In 2025 laten de prognoses voor de groep 15 tot 30-jarigen in Nederland een toename van 3,6 \%-punt zien ten opzichte van 2008.

Flevoland en Noord-Holland zijn de provincies waarvoor de meeste groei te verwachten is in de omvang van de groep 15 tot 30-jarigen. De prognoses voor de komende jaren laten met name een sterke stijging zien voor Flevoland. Na 2022 is de relatieve toename van de groep 15 tot 30-jarigen het grootst in Noord-Holland. In Groningen daalt de populatie 15 tot 30-jarigen tot en met 2016, waarna er weer een lichte toename waarneembaar is. Het tegenovergestelde kan geconcludeerd worden met betrekking tot de prognoses voor Limburg. Laatstgenoemde provincie laat een lichte stijging zien van het aantal personen in de leeftijdscategorie 15 tot 30-jarigen tot en met 2015. Daarna wordt er echter een sterke daling van deze groep voorzien. Ten opzichte van het basisjaar 2008 zal de populatie 15 tot 30-jarigen met bijna 11 \%-punt afnemen volgens de prognoses.

3. Gegevens over de bevolkingsontwikkeling zijn niet in de bijbehorende Excel-sheets zichtbaar, maar zijn wel gebruikt om de prognoses voor gediplomeerden te maken. 
Figuur 2.1

Regionale bevolkingsprognoses totale groep 15-30 jarigen, 2008-2025 (geïndexeerd op 2008=100) 4

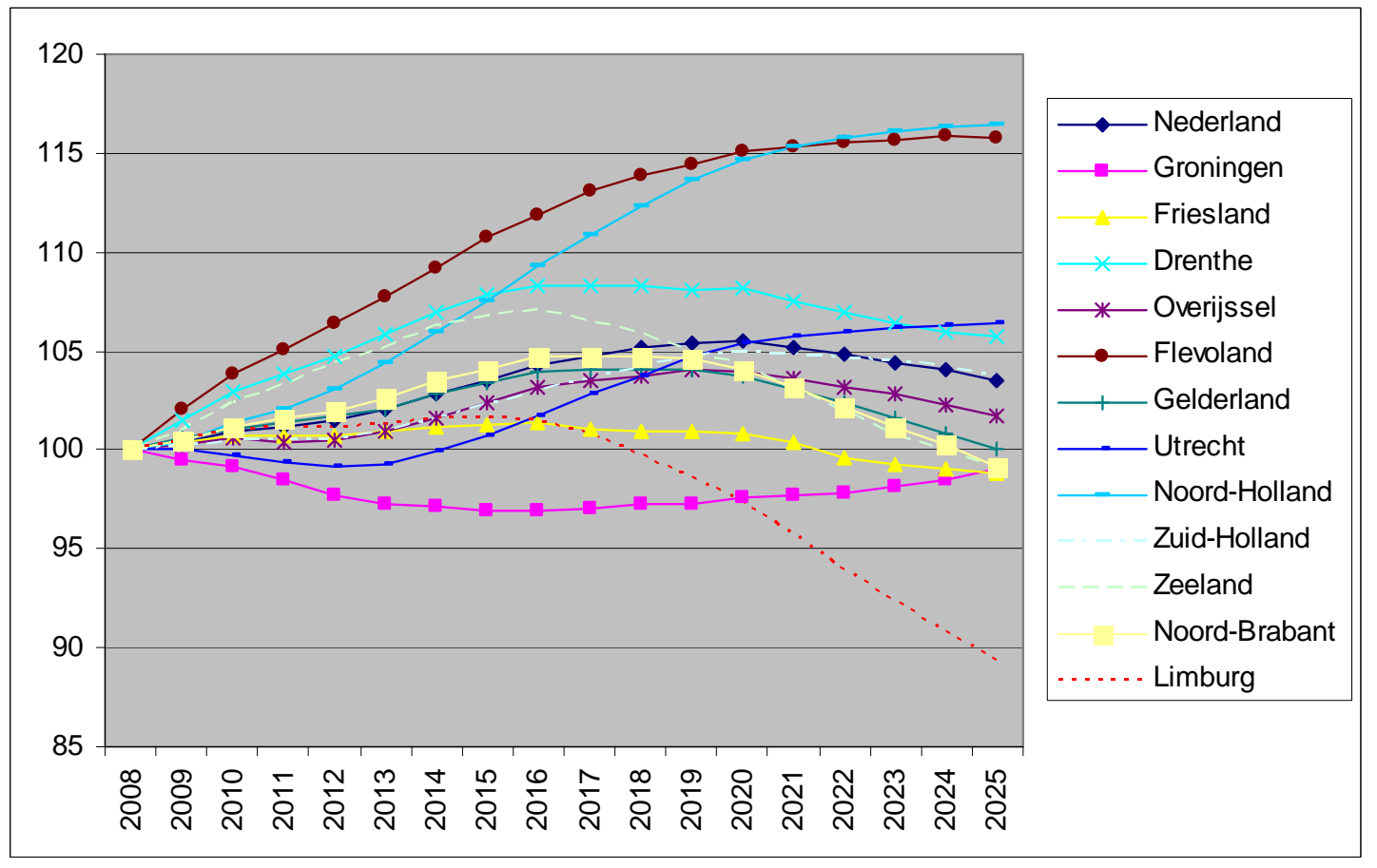

\subsection{Regionale bevolkingsprognose naar geslacht}

Om regionale verschillen in de bevolkingsontwikkeling tussen mannen en vrouwen te kunnen vergelijken, wordt de totale groep 15 tot 30-jarigen in deze paragraaf gedifferentieerd naar geslacht. Figuur 2.2 geeft de prognoses per provincie weer voor mannelijke 15 tot 30-jarigen. Figuur 2.3 geeft dezelfde prognoses weer voor vrouwen.

4. In alle figuren in dit rapport waar gebruik wordt gemaakt van indexcijfers, is het basisjaar (2008) gelijkgesteld aan 100. Vervolgens is voor elk van de jaren 2009-2025 de relatieve verandering ten opzichte van het basisjaar bepaald. Een grote relatieve verandering in deze figuren hoeft dus niet noodzakelijkerwijs ook een grote verandering in absolute zin te betekenen. Dit geldt met name voor figuren die betrekking hebben op het aandeel allochtonen of vrouwen in de techniek. 
Figuur 2.2

Regionale bevolkingsprognoses mannelijke 15-30 jarigen, 2008-2025 (geïndexeerd op 2008=100)

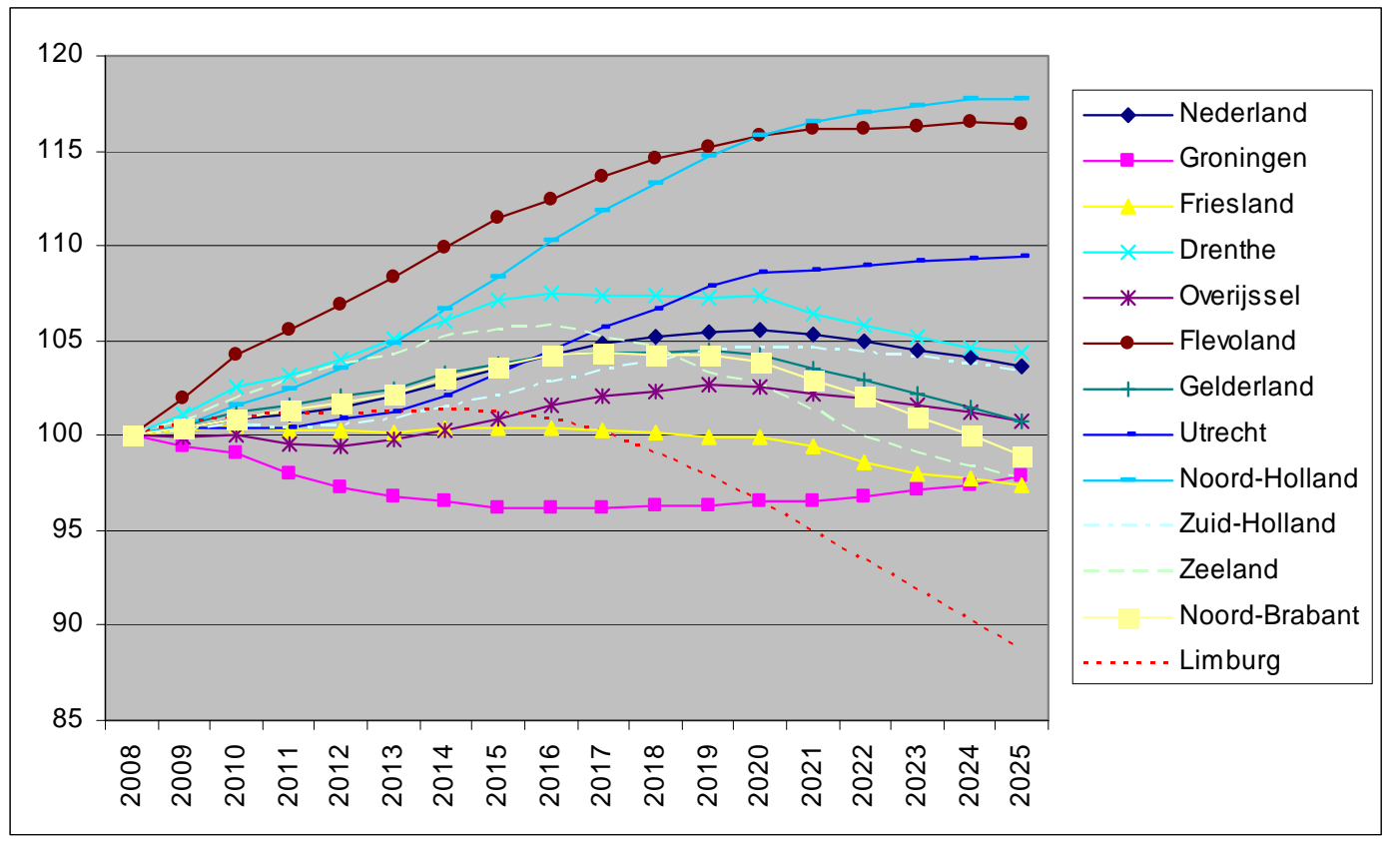

Figuur 2.2 geeft grotendeels dezelfde prognoses weer voor mannelijke 15 tot 30-jarigen als voor de eerder beschreven prognoses voor de totale groep jongeren in de leeftijd van 15 tot 30-jarigen. Alleen stijgt de populatie mannelijke 15 tot 30-jarigen in Utrecht relatief gezien meer dan de totale groep 15 tot 30-jarigen in deze provincie.

Vanzelfsprekend loopt de trend van de relatieve toename van vrouwen in Utrecht dan ook onder die van de totale groep 15 tot 30-jarigen in Utrecht, zoals ook uit figuur 2.3 geconcludeerd kan worden. In het algemeen loopt de trend van vrouwelijke 15 tot 30-jarigen in Nederland gelijk met die van mannelijke 15 tot 30-jarigen. De verschillen in de regionale prognoses tussen mannen en vrouwen blijken niet al te groot. In tegenstelling tot de populatie mannelijke jongeren, laten de prognoses in 2025 minder regionale dalingen zien ten opzichte van het basisjaar. Zo neemt het aantal vrouwen in Groningen in 2025, na een daling tot 2015, zelfs weer toe tot iets boven het niveau van het basisjaar. 
Figuur 2.3

Regionale bevolkingsprognoses vrouwelijke 15-30 jarigen, 2008-2025 (geïndexeerd op 2008=100)

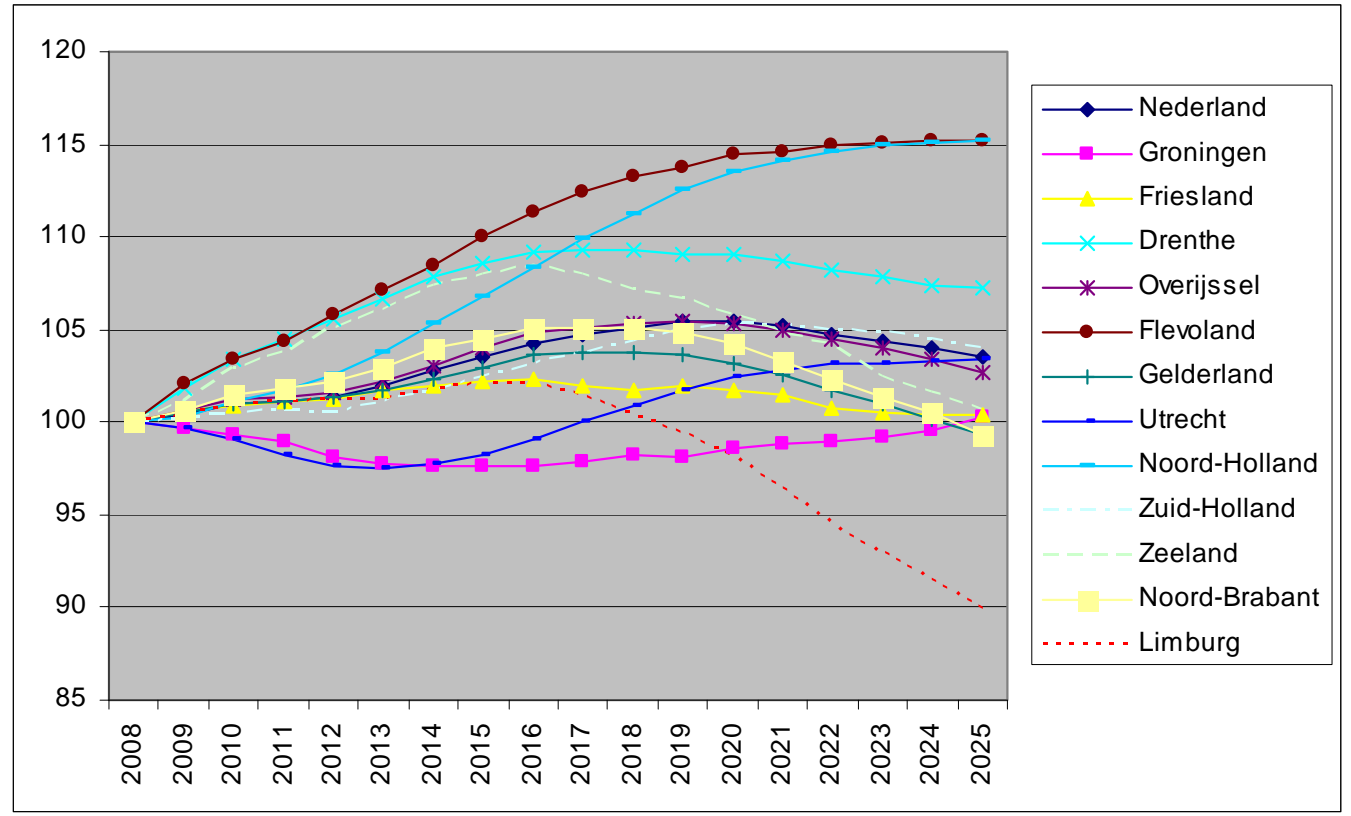

\subsection{Regionale bevolkingsprognose naar herkomst}

Naast de differentiatie naar geslacht is ook de differentiatie naar herkomst van belang in dit rapport. In deze paragraaf worden de regionale bevolkingsprognoses voor achtereenvolgens 15 tot 30-jarige autochtonen, westerse allochtonen en niet-westerse allochtonen besproken.

\section{Autochtonen}

In figuur 2.4 wordt de bevolkingsontwikkeling weergegeven voor de autochtone groep 15 tot 30 -jarigen. Het valt hierbij op dat de omvang van de groep autochtone 15 tot 30-jarigen in meerdere provincies afneemt. Dit geldt voornamelijk voor Limburg en Groningen, maar na verloop van tijd ook voor Gelderland, Noord-Brabant, ZuidHolland, Zeeland en Friesland. De totale groep autochtonen in genoemde leeftijdscategorie in Nederland blijft de eerst jaren min of meer constant. Tussen 2013 en 2020 wordt vervolgens een geringe toename verwacht, gevolgd door een lichte daling tot onder het niveau van het basisjaar. 
Figuur 2.4

Regionale bevolkingsprognoses autochtone 15-30 jarigen, 2008-2025 (geïndexeerd op 2008=100)

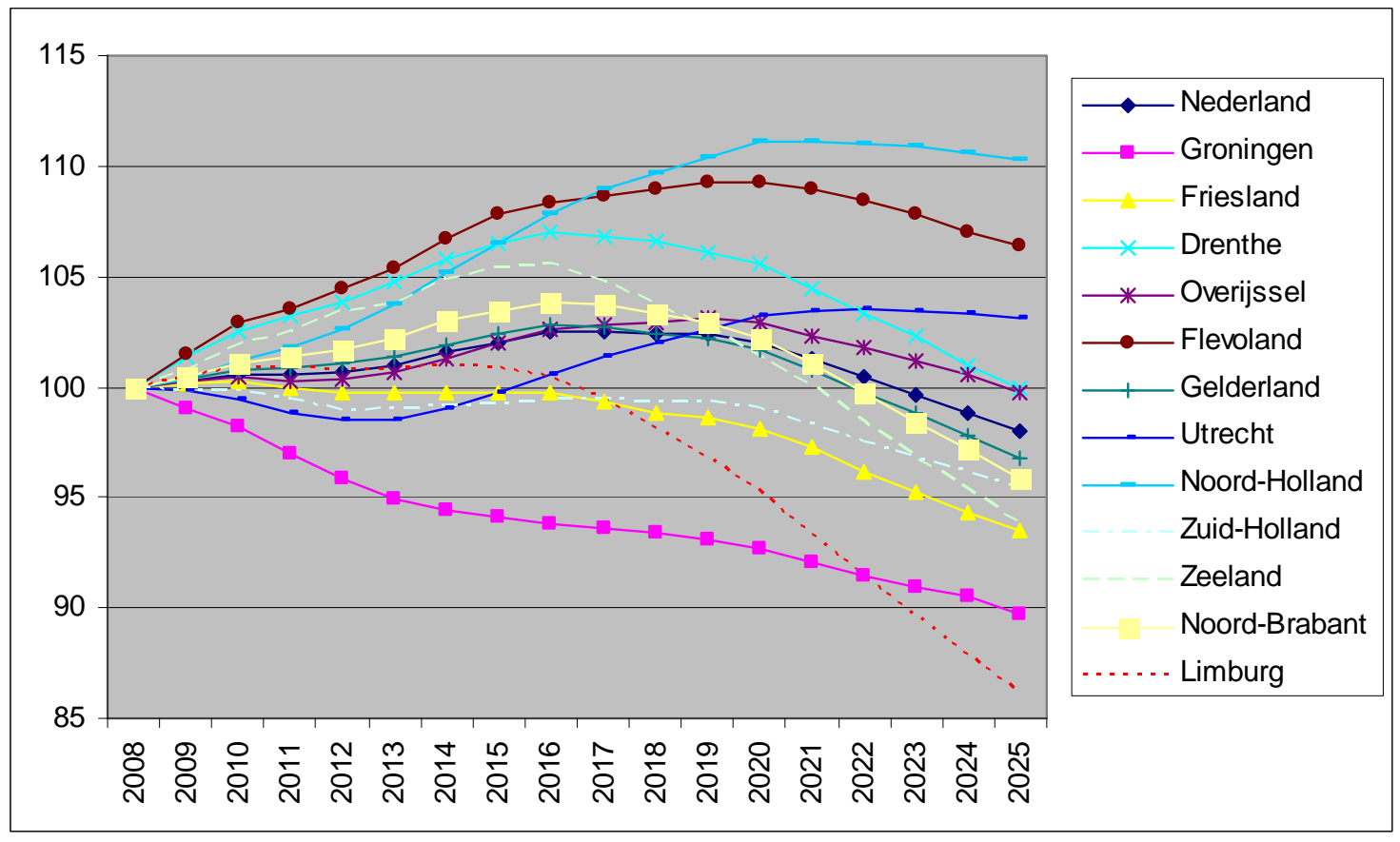

\section{Westerse allochtonen}

In figuur 2.5 zijn de regionale bevolkingsprognoses weergegeven met betrekking tot de ontwikkeling van de groep westerse allochtonen tussen 15 en 30 jaar. Nederland als geheel laat een gestaag stijgende tendens zien. In vergelijking met het basisjaar is de groep westerse allochtone jongeren in 2025 met meer dan $20 \%$-punt toegenomen.

In de meeste provincies wordt een groei voorzien van de groep westerse allochtonen in de leeftijd van 15 tot 30 jaar. De omvang van genoemde groep neemt relatief het sterkst toe in Noord-Holland, Friesland, Flevoland, Drenthe, Zuid-Holland en Groningen. De toename kan oplopen tot boven de 40 \%-punt in $2025 .{ }^{5}$ Verder is het opvallend dat de omvang van deze groep in Utrecht afneemt tot en met 2014, waarna er weer een stijgende tendens waarneembaar is tot en met 2025. De verwachting voor Limburg is dat de groep 15 tot 30-jarige westerse allochtonen, na eerst enige jaren constant te blijven, aanzienlijk zal dalen.

5. Deze op het eerste oog forse toename van het aantal westerse autochtone 15-30 jarigen in Friesland, Drenthe, Flevoland en Groningen komt neer op een absolute toename van circa 2.000 à 3.000 personen over de hele periode. 
Figuur 2.5

Regionale bevolkingsprognoses westerse allochtone 15-30 jarigen, 2008-2025 (geïndexeerd op 2008=100)

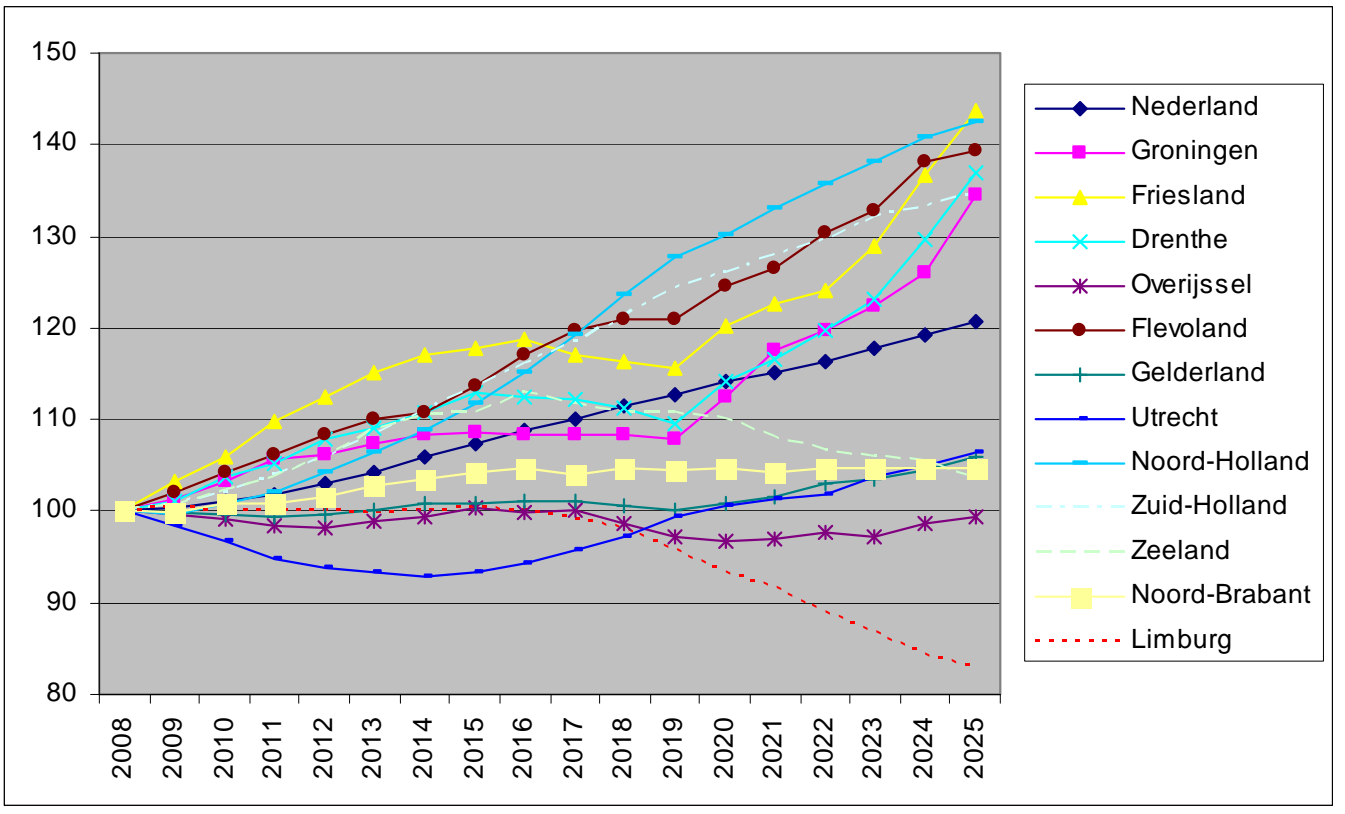

\section{Niet-westerse allochtonen}

Figuur 2.6 geeft de prognoses weer voor de groep 15 tot 30-jarige niet-westerse allochtonen. Voor Nederland als geheel wordt een toename verwacht van meer dan 20 \%-punt in 2025 ten opzichte van 2008. Deze tendens is vergelijkbaar met die van de groep 15 tot 30-jarige westerse allochtonen. Wat hierbij echter opvalt, is dat in alle 12 provincies een stijging van het aantal niet-westerse allochtonen voorzien wordt. Dit in tegenstelling tot de prognoses voor westerse allochtonen. Naar verwachting zal de groep 15 tot 30-jarige niet-westerse allochtonen in Drenthe en Groningen in 2025 zijn toegenomen met ruim 50 \%-punt ten opzichte van het basisjaar. Absoluut gezien is deze stijging echter minder spectaculair, aangezien het in beide provincies een toename betreft van respectievelijk 3.000 en 5.500 personen over de hele periode. De prognoses voor Zuid-Holland laten daarentegen relatief gezien de kleinste toename zien in de omvang van genoemde groep. Deze toename bedraagt echter nog altijd 14 \%-punt in vergelijking met 2008. 
Figuur 2.6

Regionale bevolkingsprognoses niet-westerse allochtone 15-30 jarigen, 2008-2025 (geïndexeerd op 2008=100)

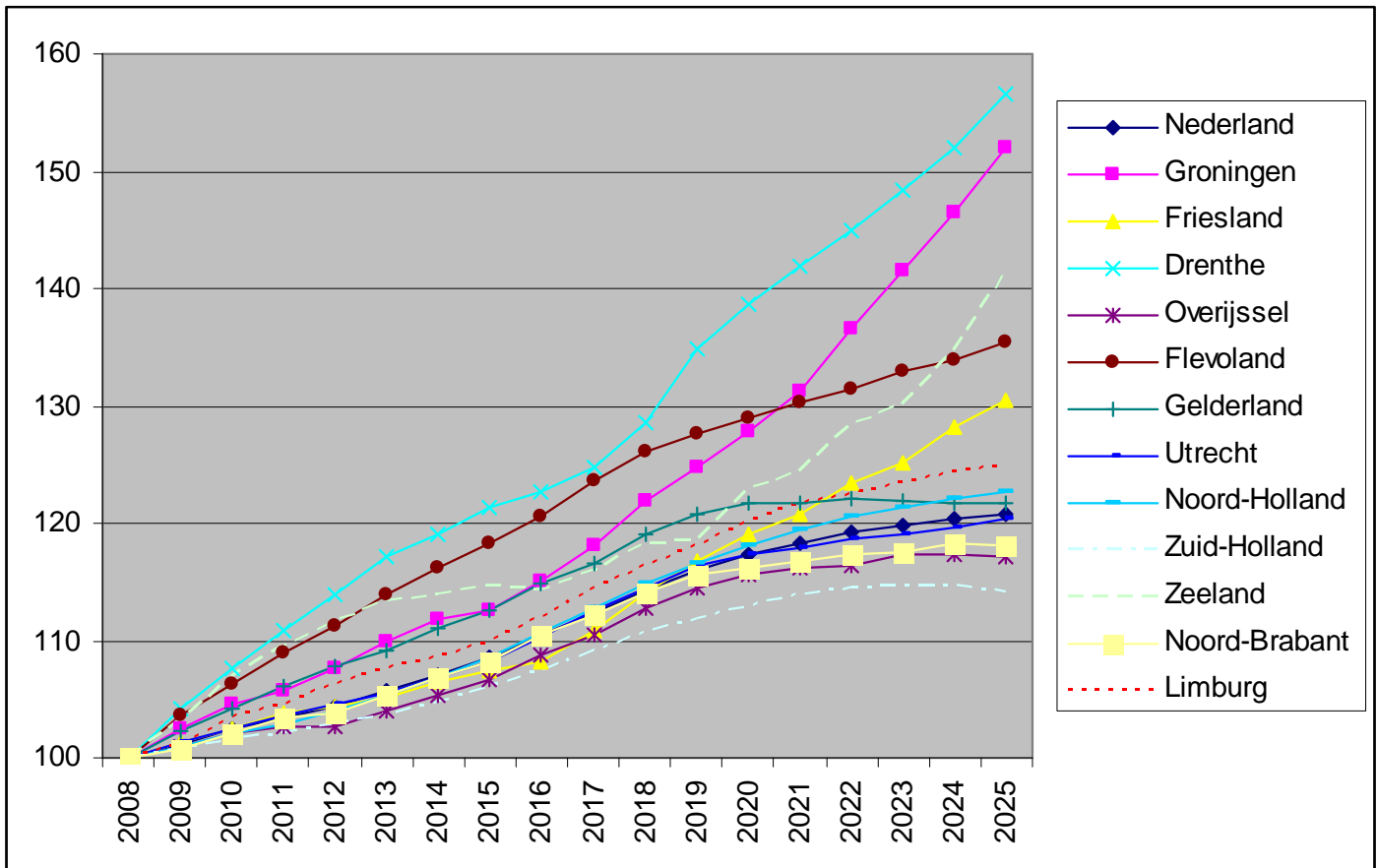

Uit de figuren 2.4, 2.5 en 2.6 zou het beeld kunnen ontstaan dat er aanzienlijke veranderingen zullen optreden in de verhouding tussen het aandeel autochtonen, westerse en niet-westerse allochtonen in Nederland. Uit figuur 2.7 kan echter geconcludeerd worden dat er nauwelijks sprake is van verschuivingen in de aandelen van genoemde groepen binnen de leeftijdsklasse van 15 tot 30-jarigen. In 2008 is driekwart van alle 15 tot 30-jarigen in Nederland autochtoon en in 2025 is volgens deze prognoses nog steeds ruim $71 \%$ van de 15 tot 30 -jarigen autochtoon. Het aandeel westerse en niet-westerse allochtonen neemt tussen 2008 en 2025 met respectievelijk 1,3 en 2,7\%-punt toe. In 2025 is naar verwachting 9,5\% binnen de leeftijdsklasse van 15- tot 30-jarigen westers allochtoon, terwijl 19,2\% niet-westers allochtoon is. 
Figuur 2.7

Verhouding tussen herkomstgroepen op basis van bevolkingsprognoses 15-30 jarigen, 2008, 2015, 2025

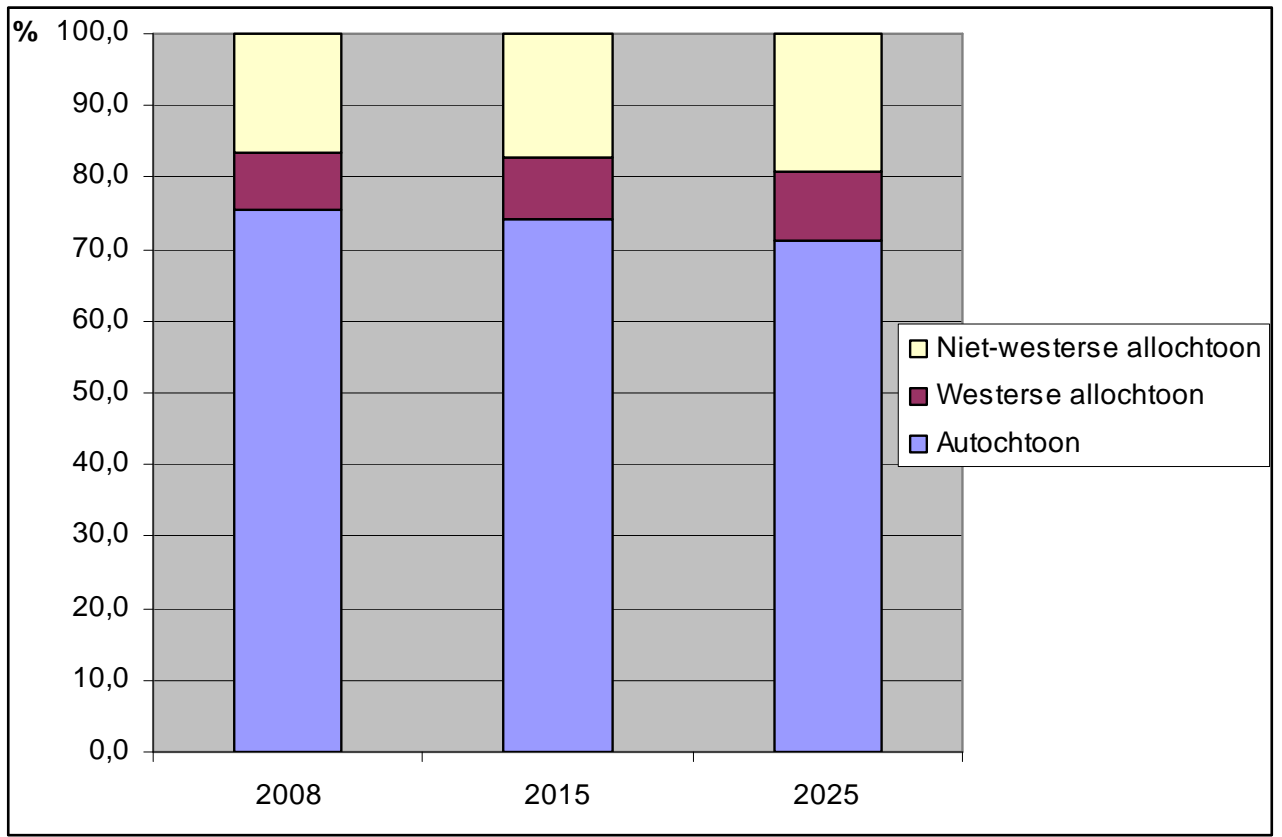




\section{Basisscenario technisch opgeleiden tot 2025}

Van belang voor de regionale ramingen van geslaagden tot 2025 is de nationale groei van het aantal geslaagden in het mbo, hbo en wo volgens de Referentieraming 2008. Er is voor dit rapport en de bijgehorende Excelsheets (de 'tool') gebruik gemaakt van een gemiddeld groeicijfer uit de Referentieraming 2008 van het aantal geslaagden op mbo-, hbo- en wo-niveau in de bevolking van 15 jaar en ouder per opleidingsniveau tot 2020. Voor elke leeftijdscategorie is hetzelfde groeicijfer naar opleidingsniveau opgelegd, omdat er in de Referentieramingen niet wordt gedifferentieerd naar leeftijdscategorie. Voor de jaren na 2020 is geen verdere groei verondersteld van het aandeel geslaagden per opleidingsniveau in de bevolking van 15 jaar en ouder.

\subsection{Mbo-gediplomeerden}

Figuur 3.1

Absoluut aantal afgestudeerden mbo techniek, 2008-2025

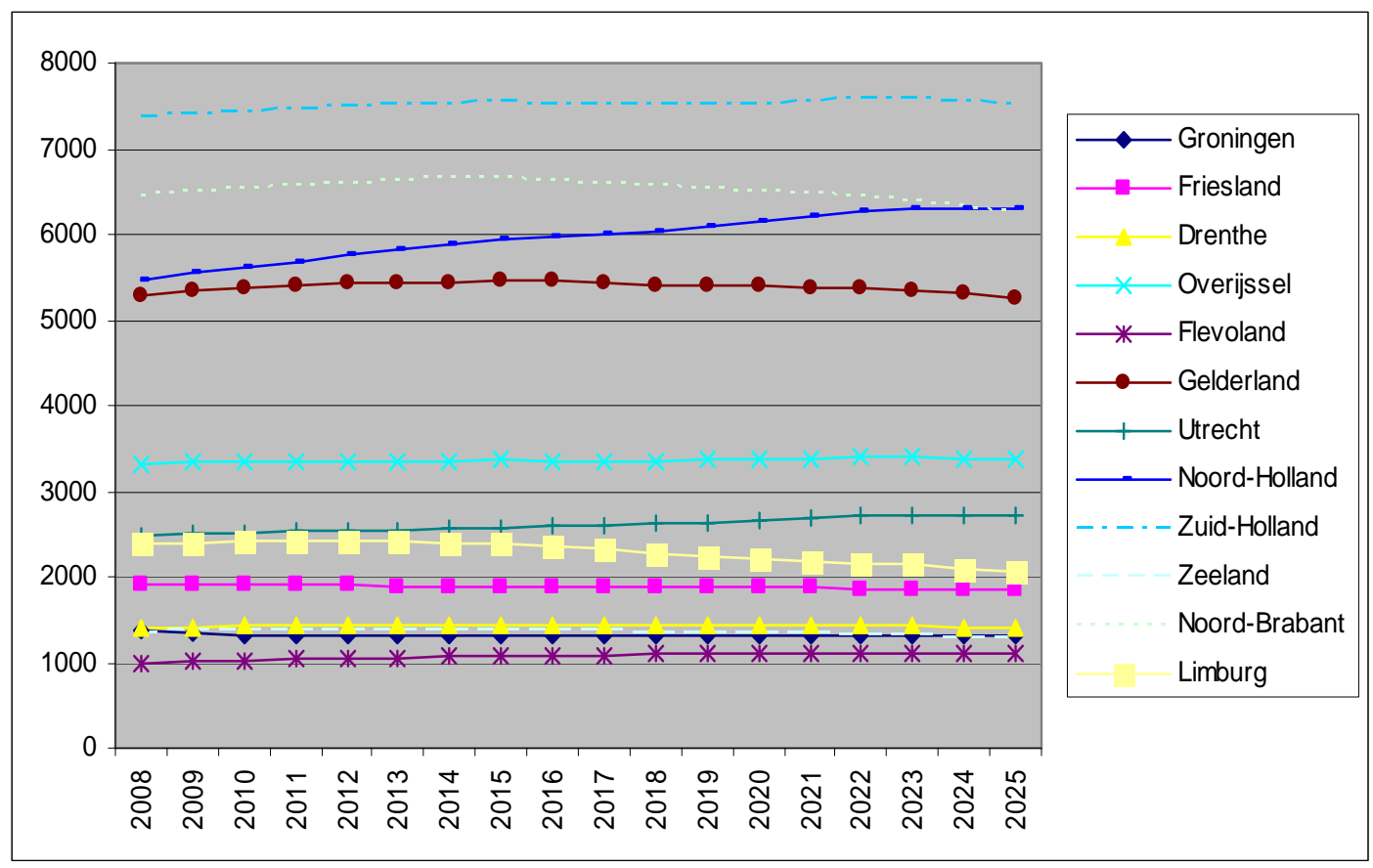

De prognoses in figuur 3.1 laten zien dat de provincie Zuid-Holland absoluut gezien de meeste afgestudeerde personen mbo techniek levert gedurende de hele periode 2008-2025. Ook in Noord-Brabant, Gelderland en Noord-Holland studeren veel jongeren af met een diploma mbo techniek. In tegenstelling tot alle andere provincies wordt in laatstgenoemde provincie een flinke groei voorzien van het aantal afgestudeerden mbo techniek. De prognoses voor het aantal gediplomeerden mbo techniek in de overige provincies zijn min of meer constant. 
Figuur 3.2

Relatief aantal afgestudeerden mbo techniek, 2008-2025 (geïndexeerd op 2008=100)

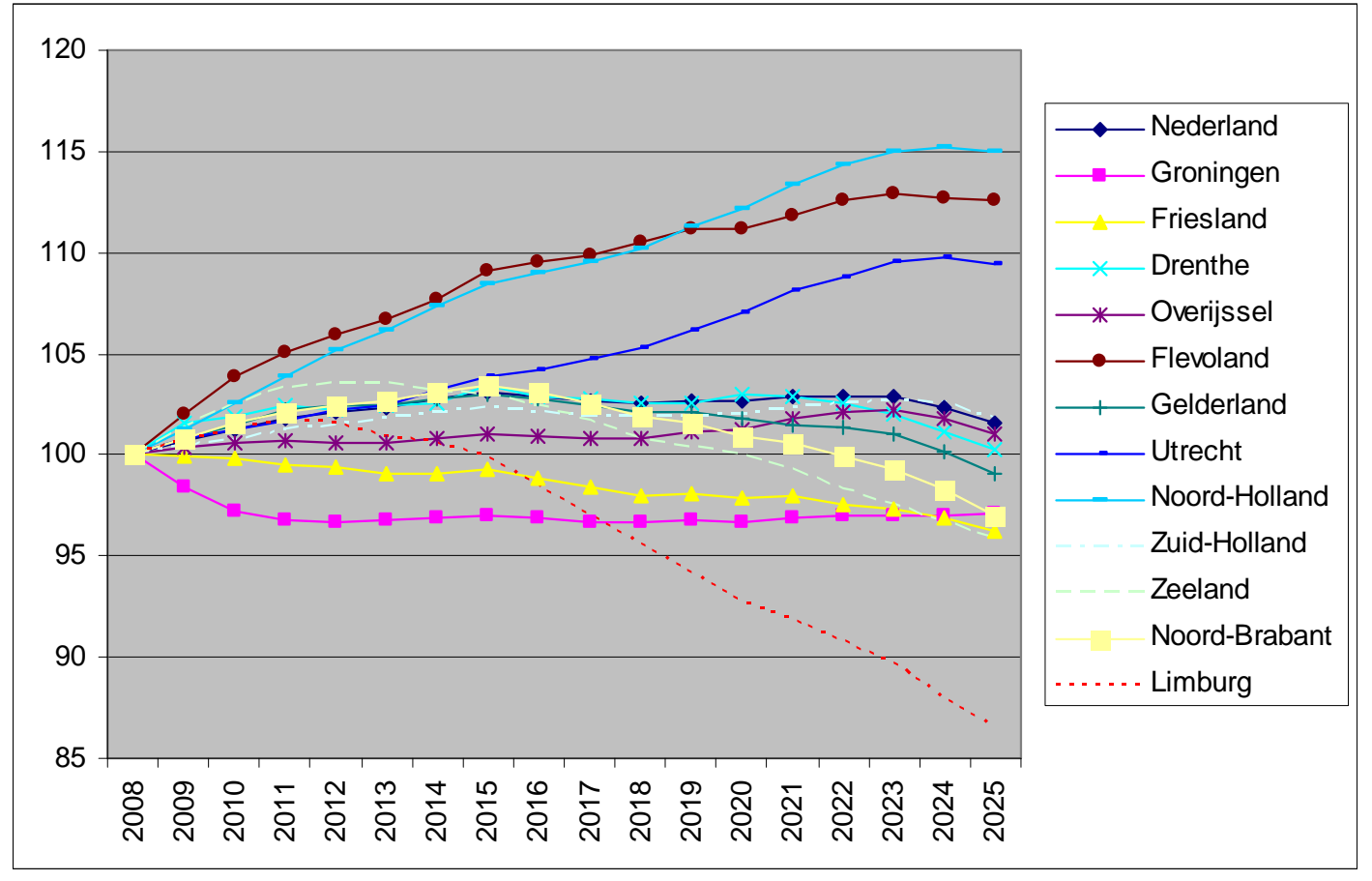

Uit figuur 3.2 kan geconcludeerd worden dat het totale aantal afgestudeerden mbo techniek in drie provincies behoorlijk zal toenemen. In Noord-Holland, Flevoland en Utrecht wordt een behoorlijke stijging voorzien van de totale groep afgestudeerden mbo techniek. De toename in deze provincies ligt tussen de 10 en 15 \%-punt in 2025 ten opzichte van het basisjaar 2008. Limburg laat daarentegen een daling zien van bijna $15 \%$-punt in dezelfde periode. Afnames van minder dan 5 \%-punt in 2025 worden voorzien voor Groningen, Friesland, Gelderland, Zeeland en Noord-Brabant. In de laatste drie provincies, en ook in Limburg, is echter eerst nog een stijging te zien. De prognoses voor Nederland als geheel laten een lichte stijging zien, gevolgd door een lichte daling. Tussen 2008 en 2025 komt de toename van het aantal afgestudeerden mbo techniek in Nederland nauwelijks boven de 3 \%-punt uit. 
Figuur 3.3

Absoluut aantal afgestudeerde mannen mbo techniek, 2008-2025

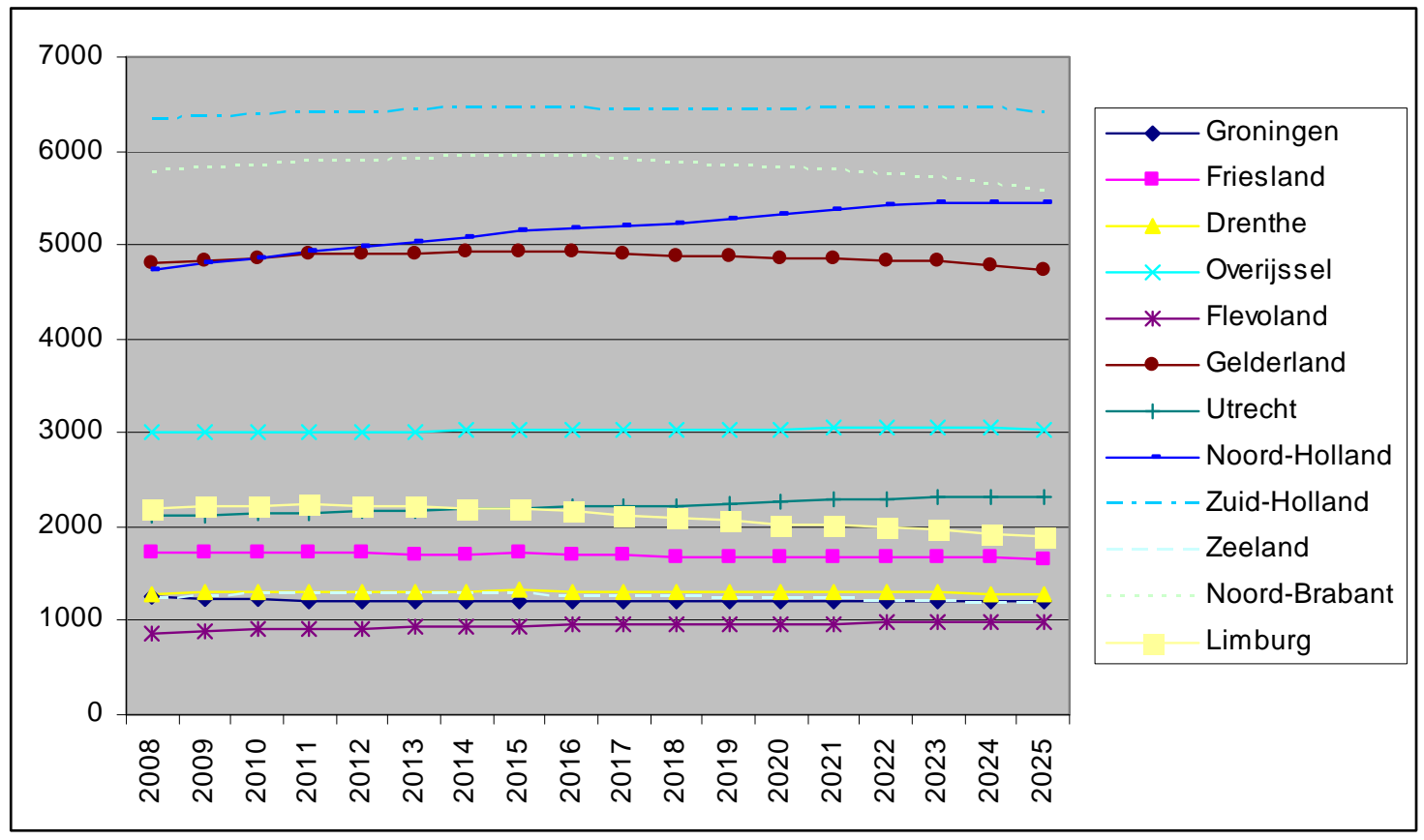

Figuur 3.3 geeft per provincie de prognoses weer voor mannelijke gediplomeerden mbo techniek voor de periode 2008-2025. In Zuid-Holland, Noord-Brabant, Noord-Holland en Gelderland wonen de meeste mannelijke gediplomeerden mbo techniek.

Uit figuur 3.4 blijkt vervolgens dat het aantal mannelijke afgestudeerden mbo techniek in Nederland als geheel de eerste jaren iets zal stijgen, gevolgd door een lichte daling na 2015. In vergelijking met het basisjaar zal het aantal mannelijke gediplomeerden mbo techniek in Noord-Holland, Flevoland en Utrecht flink toenemen. In Limburg daarentegen neemt het aantal mannelijke gediplomeerden mbo techniek met bijna 14\% af in 2025 ten opzichte van het basisjaar. 
Relatief aantal afgestudeerde mannen mbo techniek, 2008-2025 (geïndexeerd op 2008=100)

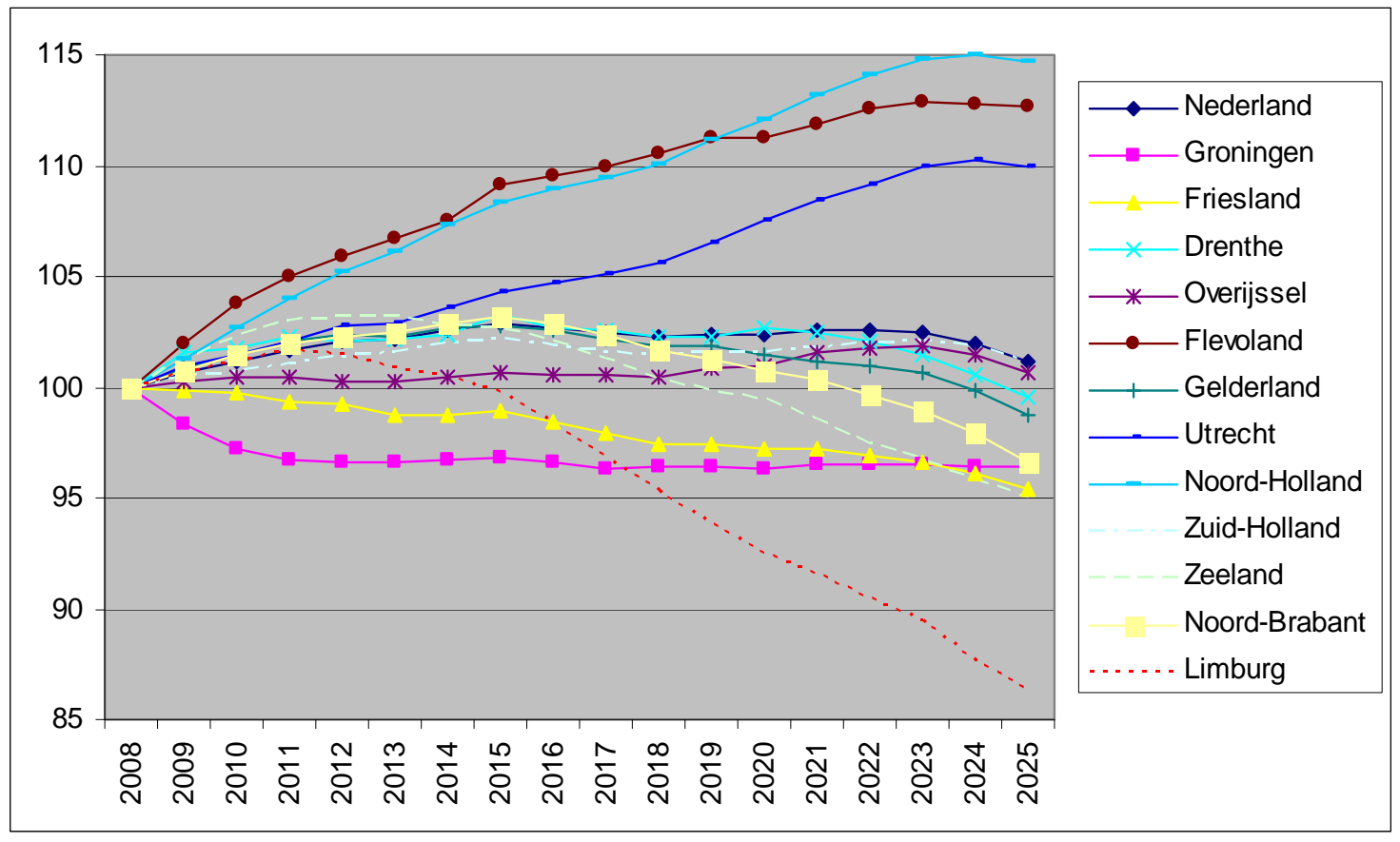

Figuur 3.5 en 3.6 geven respectievelijk de prognoses weer voor de absolute en relatieve ontwikkeling van het aantal vrouwelijke gediplomeerden mbo techniek. Zuid-Holland heeft de meeste vrouwelijke gediplomeerden mbo techniek levert, wat overeenkomt met de situatie bij de mannen. Voor vrouwen geldt echter dat NoordHolland de op één na succesvolste provincie is wat betreft het aantal vrouwelijke gediplomeerden mbo techniek, gevolgd door Noord-Brabant. Bij de mannen was dit net andersom. Verder valt het in figuur 3.5 op dat ook Overijssel en Utrecht stuivertje wisselen bij de vrouwen in vergelijking met de mannen in figuur 3.3.

Zoals blijkt uit figuur 3.6 hebben Noord-Holland en Flevoland, evenals bij de mannen, relatief de meeste vrouwen met een diploma mbo techniek. Het grootste verschil is echter dat het aantal vrouwelijke gediplomeerden mbo techniek in de meeste provincies gegroeid is in 2025 ten opzichte van 2008, terwijl dit bij mannen in meerdere provincies niet het geval is. 
Figuur 3.5

Absoluut aantal afgestudeerde vrouwen mbo techniek, 2008-2025

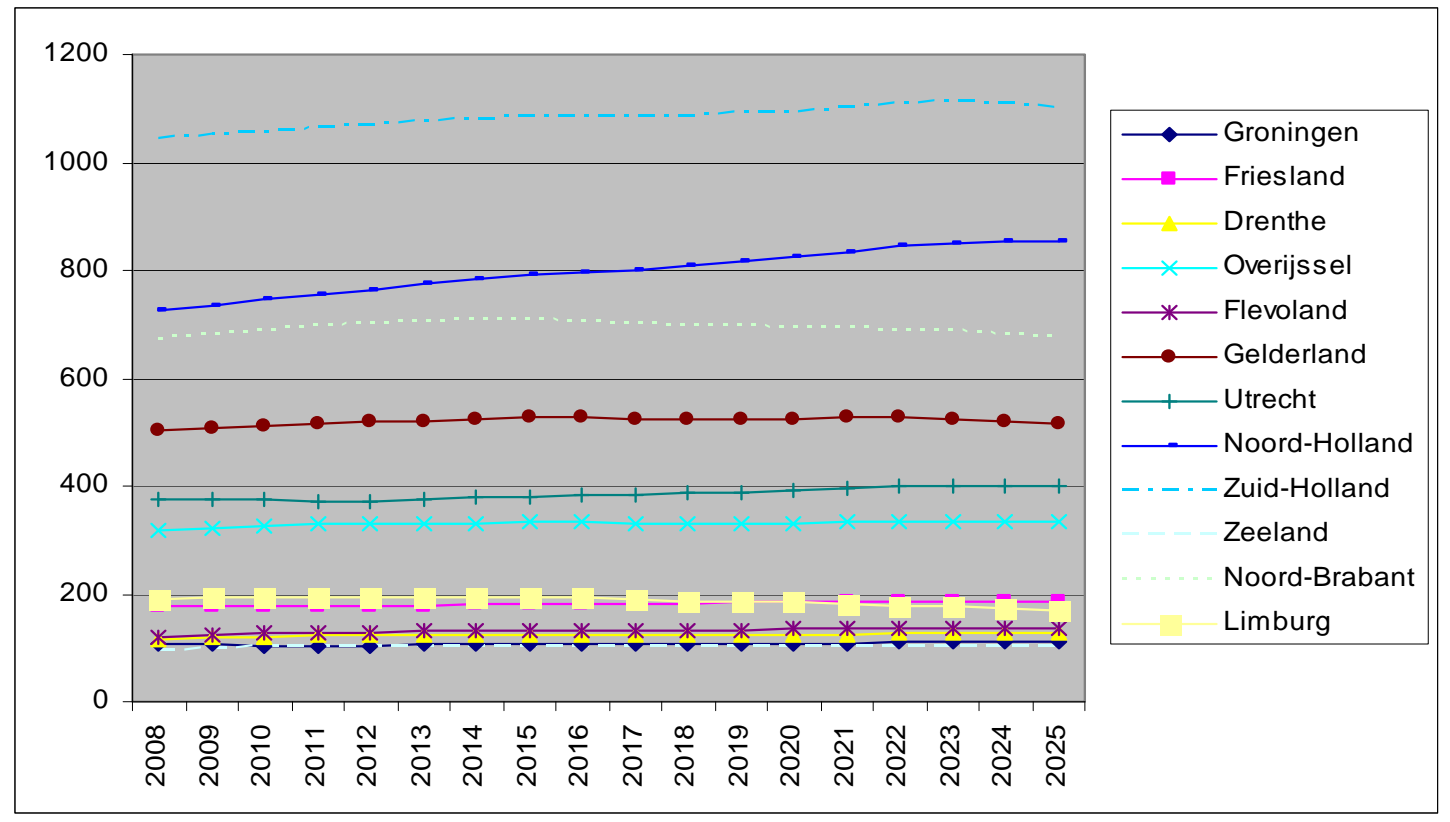

Figuur 3.6

Relatief aantal afgestudeerde vrouwen mbo techniek, 2008-2025 (geïndexeerd op 2008=100)

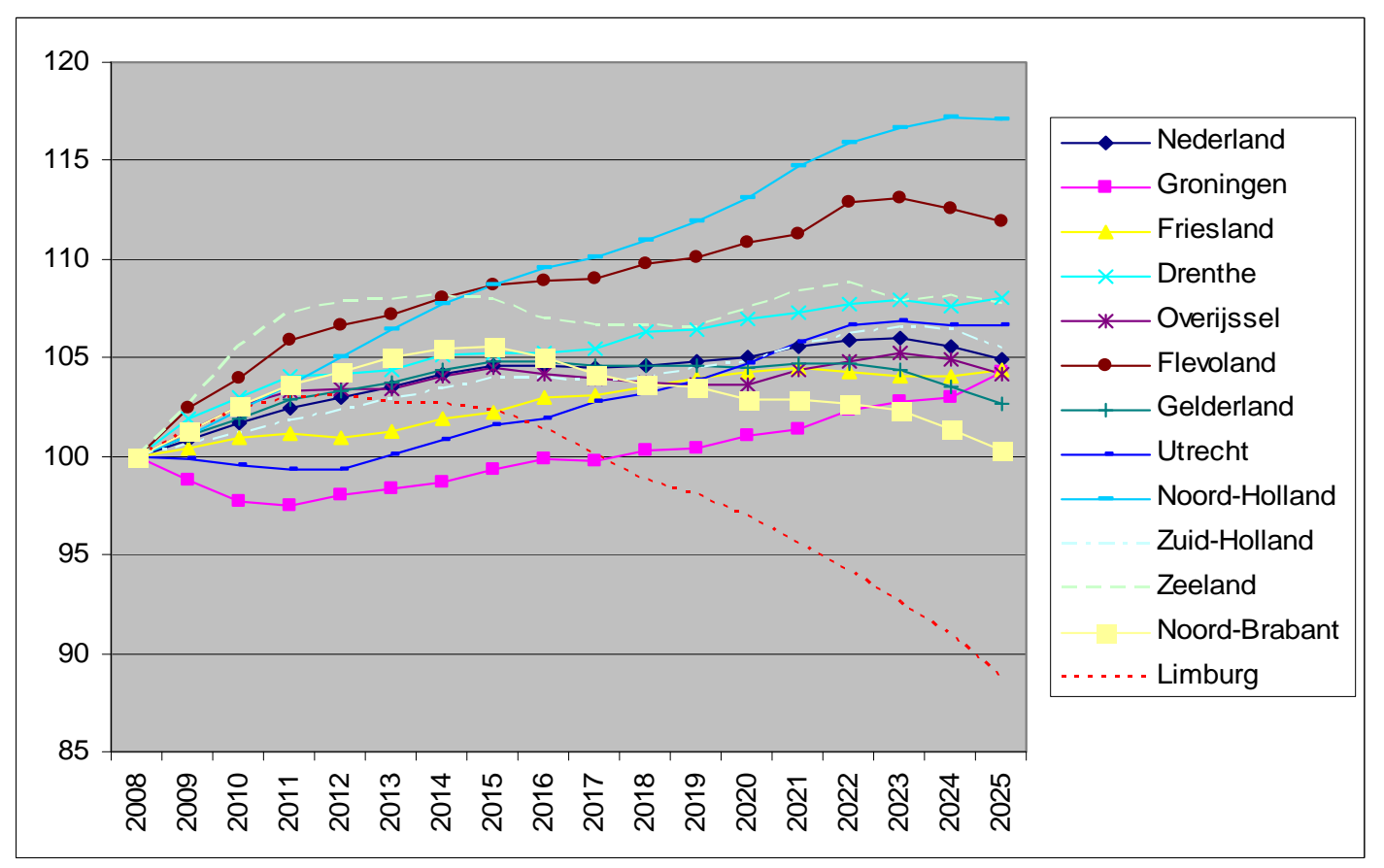


Figuur 3.7

Absoluut aantal afgestudeerde autochtonen mbo techniek, 2008-2025

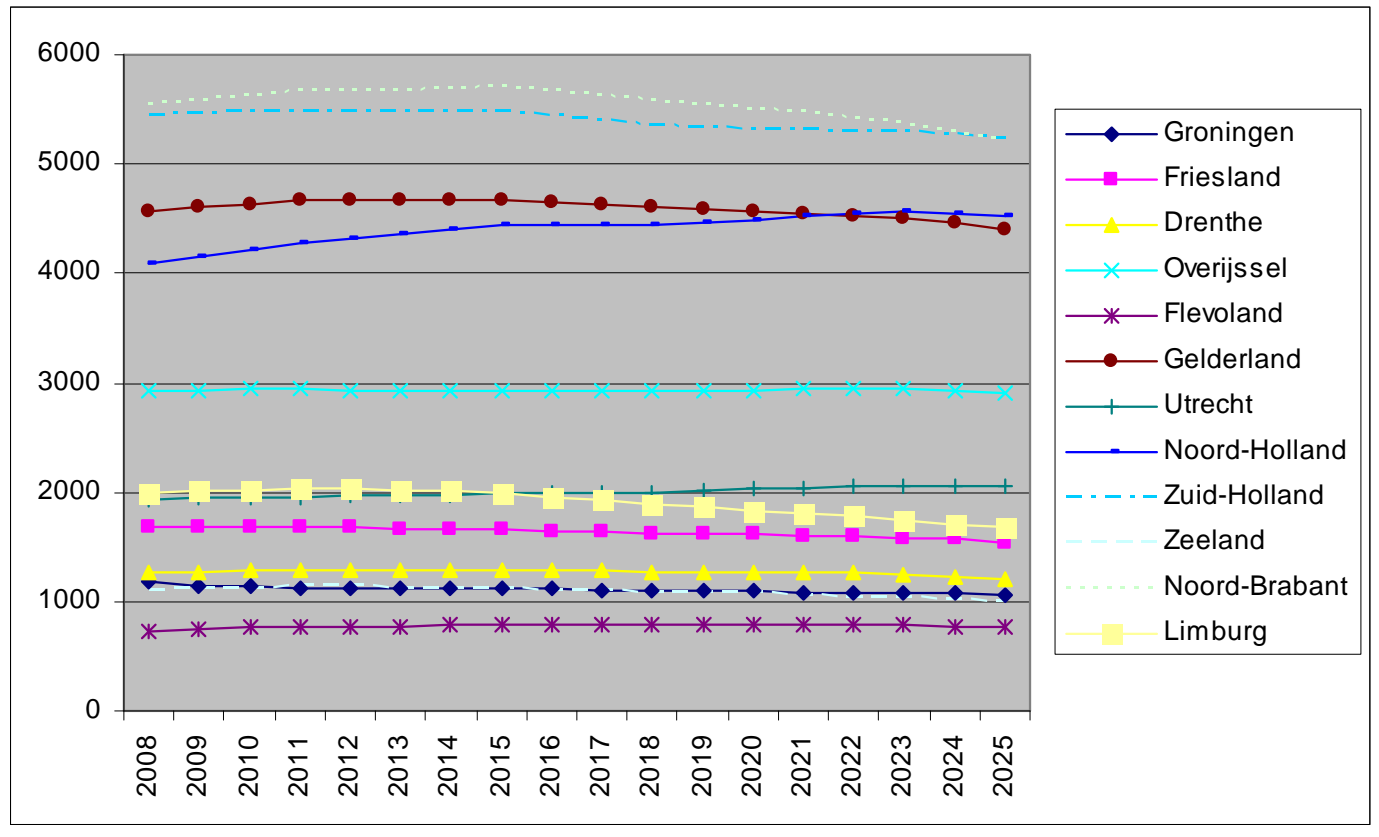

Naast de prognoses voor de totale aantallen gediplomeerden mbo techniek en de prognoses gedifferentieerd naar geslacht, worden ook de prognoses weergegeven van de gediplomeerden mbo techniek gedifferentieerd naar herkomst. Figuur 3.7 geeft de prognoses weer voor het totale aantal autochtone afgestudeerden mbo techniek. Noord-Brabant en Zuid-Holland zijn de provincies die het meest succesvol zijn wat betreft het aantal gediplomeerden mbo techniek. Ook Gelderland en Noord-Holland zullen de komende jaren een aanzienlijk aantal autochtone mbo technici afleveren. Noord-Holland laat daarbij, in tegenstelling tot de drie andere provincies, een stijgende tendens zien. De prognoses voor de overige provincies zijn redelijk constant voor de periode tot en met 2025. Een uitzondering hierop is Limburg, dat in de loop der tijd steeds minder autochtone gediplomeerden mbo techniek zal hebben. 
Relatief aantal afgestudeerde autochtonen mbo techniek, 2008-2025 (geïndexeerd op 2008=100)

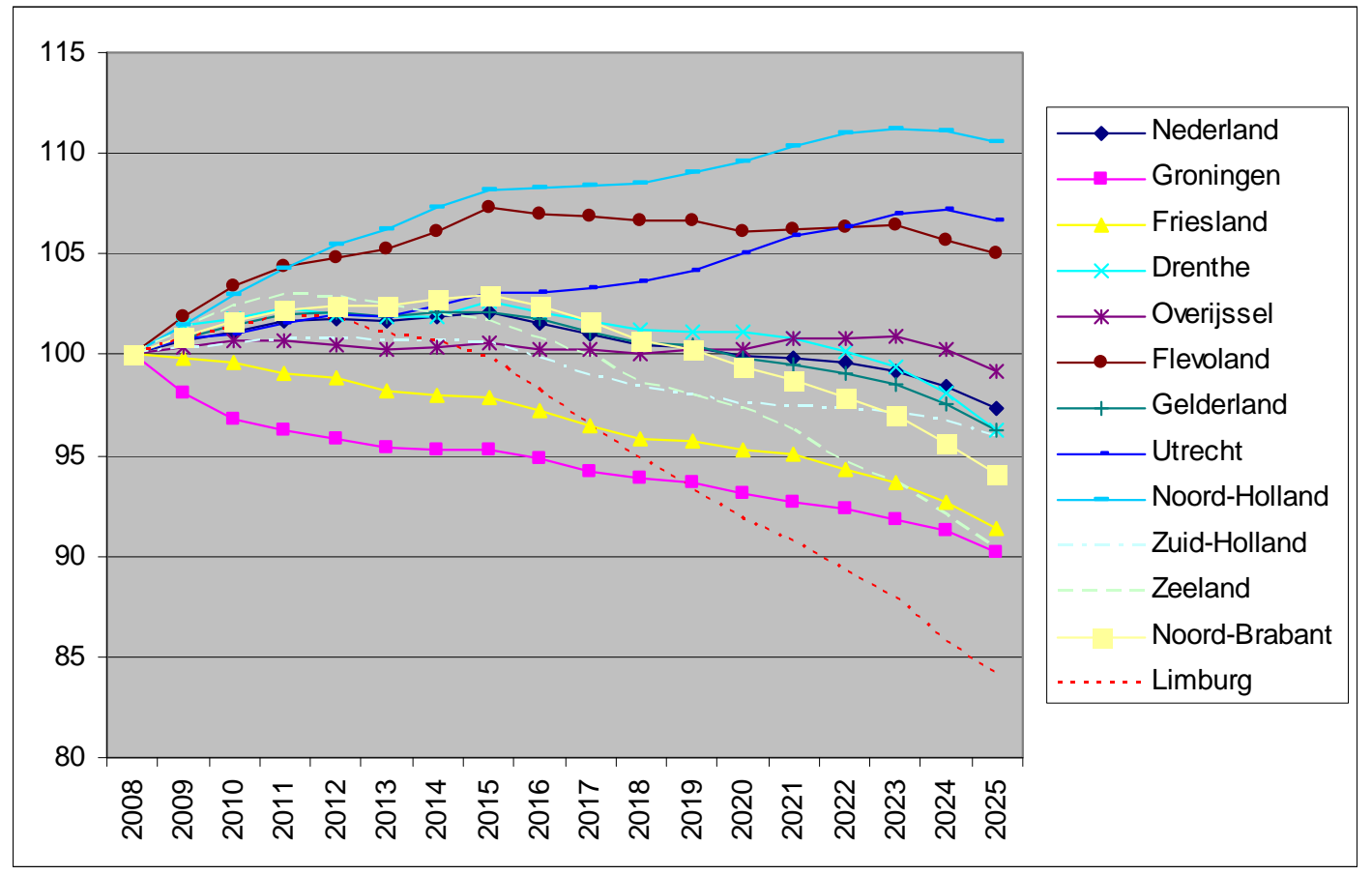

In vergelijking met de in figuur 3.2 weergegeven prognoses voor de totale groep afgestudeerden mbo techniek, kan met betrekking tot de autochtone afgestudeerden mbo techniek geconcludeerd worden dat er een geringere toename van deze groep autochtonen in 2025 is in Noord-Holland, Flevoland en Utrecht. Deze prognoses voor de ontwikkeling van het totale aantal afgestudeerde autochtonen mbo techniek zijn afgebeeld in figuur 3.8. Uit dezelfde figuur kan geconcludeerd worden dat er in 2025 zelfs sprake is van een afname van het aantal autochtone afgestudeerden mbo techniek in alle negen overige provincies. Met name Limburg springt er in negatieve zin bovenuit, met een afname van bijna 16 \%-punt in 2025 ten opzichte van het basisjaar. Het aantal autochtone mbo'ers techniek in Nederland als geheel neemt tot en met 2015 enigszins toe. Na 2015 zal echter een lichte daling ingezet worden. 
Figuur 3.9

Absoluut aantal afgestudeerde westerse allochtonen mbo techniek, 2008-2025

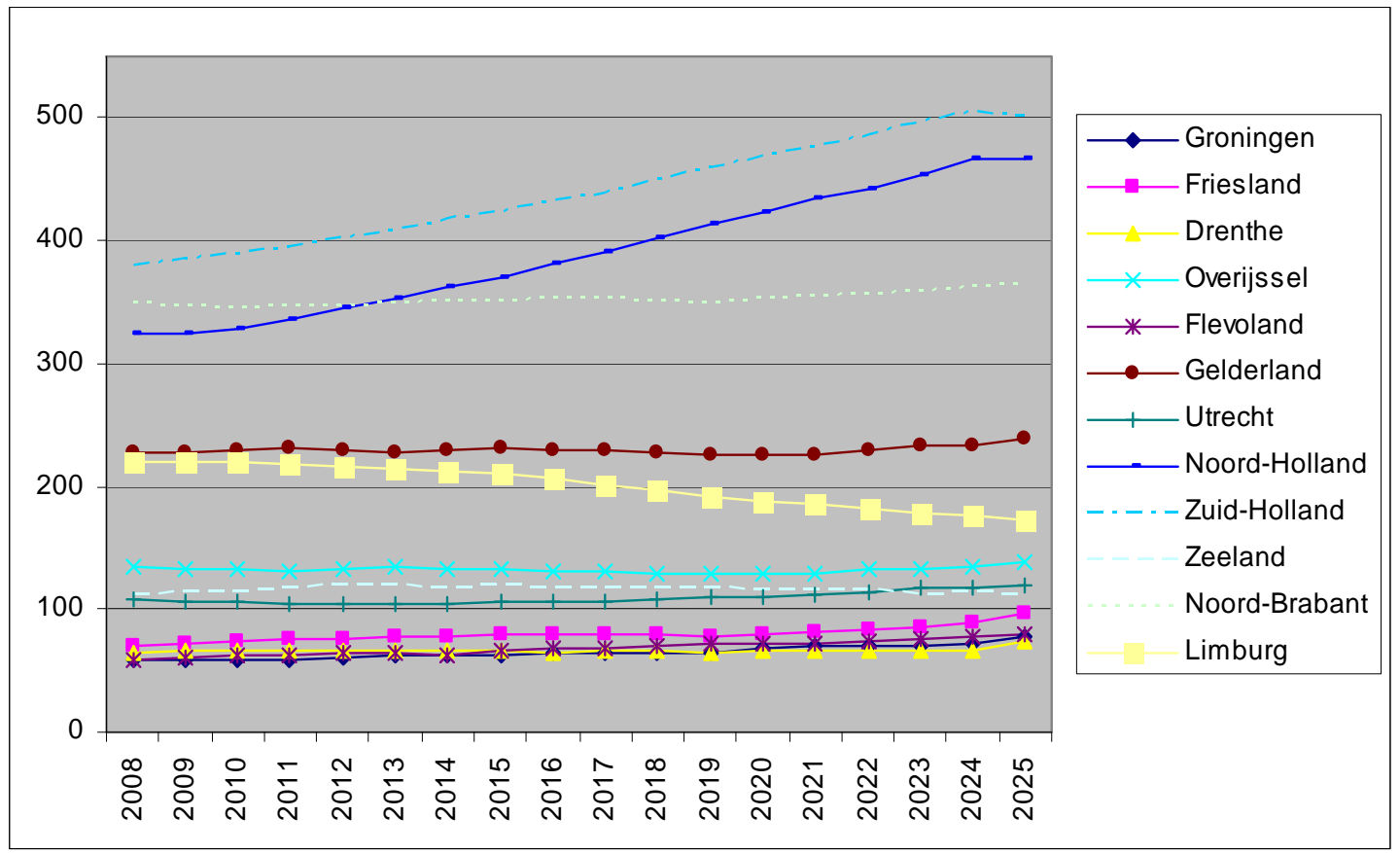

Figuur 3.9 toont de prognoses van het totale aantal afgestudeerde westerse allochtonen mbo techniek per provincie. Afgestudeerde westerse allochtonen behalen hun mbo-diploma techniek de komende jaren voornamelijk in Zuid- en Noord-Holland. Beide provincies laten een sterke stijging zien. Ook in Noord-Brabant zijn er absoluut gezien veel afgestudeerde westerse allochtonen te vinden met een mbo-diploma techniek. In vergelijking met beide eerder genoemde provincies vertoont de prognose voor Noord-Brabant echter nauwelijks groei. De prognoses voor Limburg laten een dalende tendens zien wat betreft het aantal westerse allochtonen mbo techniek. 
Figuur 3.10

Relatief aantal afgestudeerde westerse allochtonen mbo techniek, 2008-2025 (geïndexeerd op 2008=100)

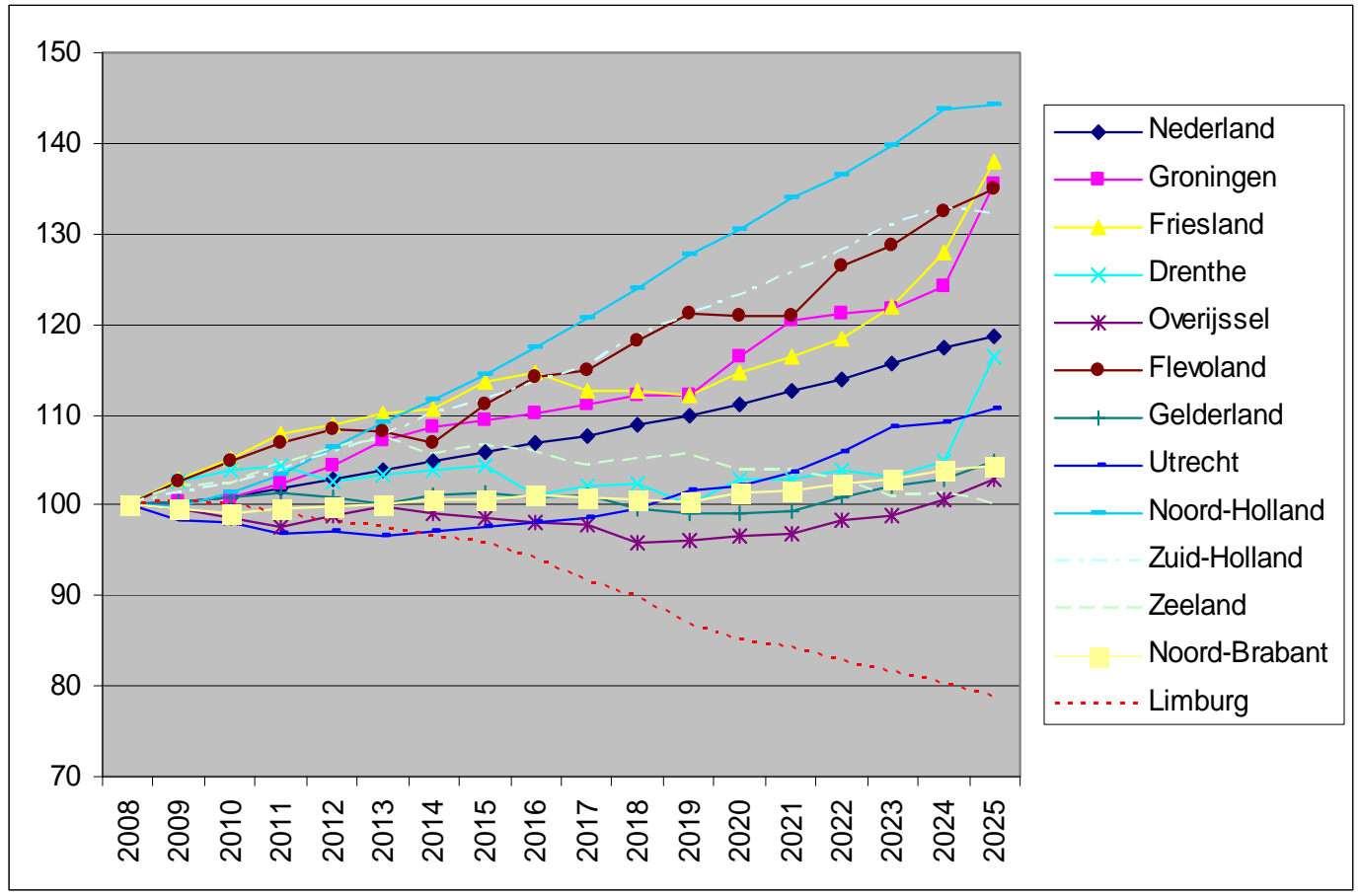

Figuur 3.10 laat zien dat er, vergeleken met het basisjaar, een stijging van het aantal afgestudeerde westerse allochtonen mbo techniek wordt voorzien in nagenoeg elke provincie. Limburg is de enige echte uitzondering en zorgt daarmee voor een flinke negatieve uitschieter met een daling van meer dan 21 \%-punt in 2025. Daar staat tegenover dat Noord-Holland voor de sterkste stijging zorgt van het aantal westerse allochtonen met een mbodiploma techniek (44,3 \%-punt). Ook Friesland, Groningen, Flevoland en Zuid-Holland zorgen voor een relatief sterke stijging van het aantal westerse allochtonen met een diploma mbo techniek.

De totale groep westerse allochtonen met een diploma mbo techniek in Nederland laat een bijna lineaire toename zien over de gehele periode. Het is de verwachting dat deze groep in 2025 met bijna 19 \%-punt gestegen is ten opzichte van het basisjaar. 
Figuur 3.11

Absoluut aantal afgestudeerde niet-westerse allochtonen mbo techniek, 2008-2025

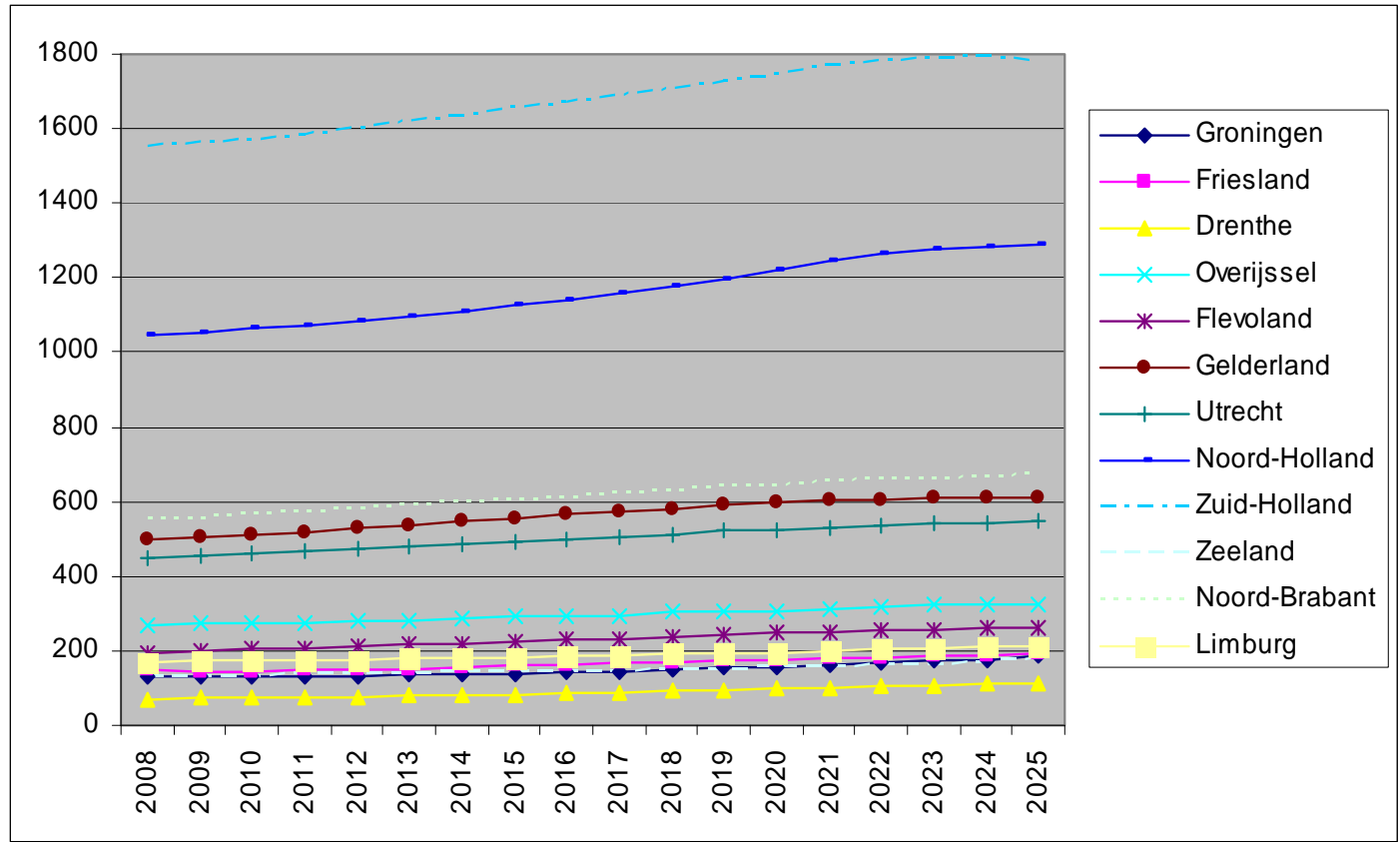

Figuur 3.11 geeft het aantal niet-westerse allochtonen met een mbo-diploma techniek weer tot en met 2025. Zuid-Holland levert wederom de meeste mbo-technici, gevolgd door Noord-Holland. In beide provincies wordt de komende jaren bovendien nog een behoorlijke stijging voorzien. Ook in alle andere provincies laten de prognoses een toename zien van het aantal niet-westerse mbo-gediplomeerden in de techniek. In deze provincies is er sprake van een lichte toename. 
Figuur 3.12

Relatief aantal afgestudeerde niet-westerse allochtonen mbo techniek, 2008-2025 (geïndexeerd op 2008=100)

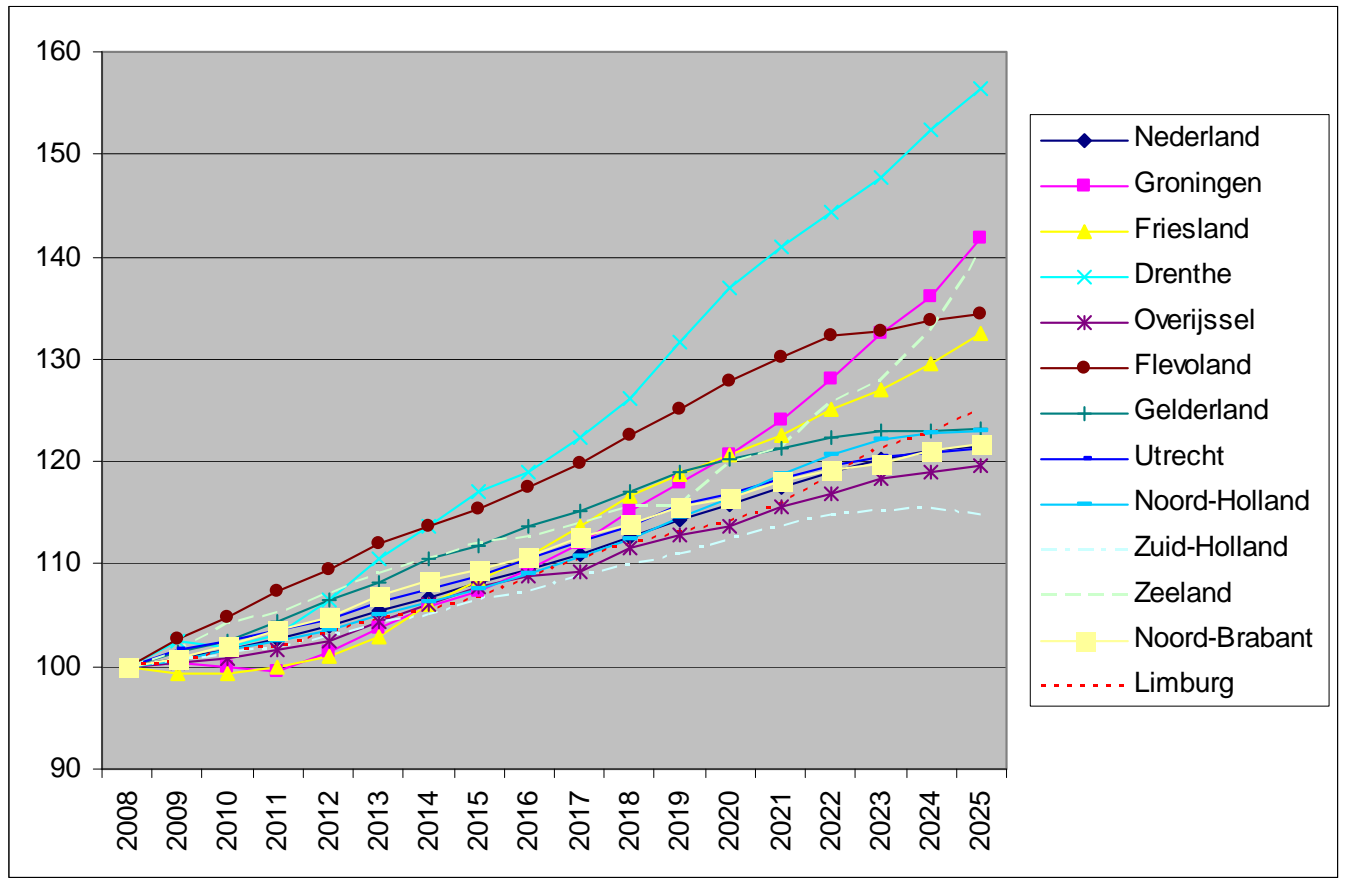

Uit de prognoses in figuur 3.12 kan geconcludeerd worden dat in alle provincies een toename verwacht wordt van het aantal niet-westerse personen met een diploma mbo techniek. Drenthe heeft de komende jaren de sterkste stijging van het aantal niet-westerse afgestudeerden mbo techniek. In Flevoland stijgt deze groep de eerstkomende jaren zelfs nog sneller, maar neemt het aantal na enkele jaren minder snel toe dan in Drenthe. Ook Groningen, Zeeland en Friesland hebben in 2025 aanzienlijk meer afgestudeerde niet-westerse allochtonen mbo techniek in vergelijking met het basisjaar. De verwachte trend voor Nederland loopt nagenoeg gelijk met die van de provincie Utrecht. In 2025 is het aantal niet-westerse gediplomeerden mbo techniek in Nederland toegenomen met 21,5 \%-punt in vergelijking met het basisjaar. 


\subsection{Hbo-gediplomeerden}

Figuur 3.13

Absoluut aantal afgestudeerden hbo techniek, 2008-2025

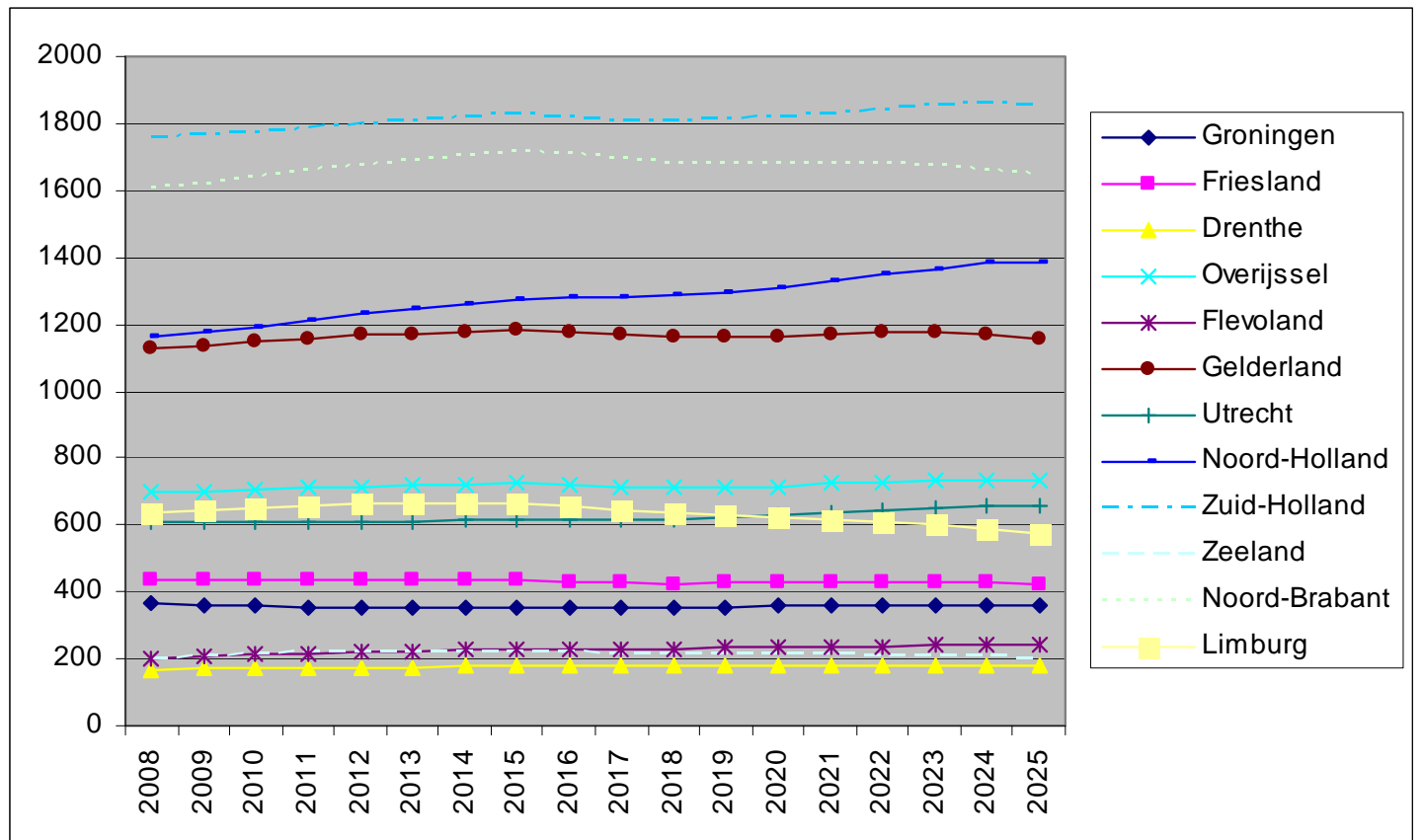

Figuur 3.13 laat zien dat Zuid-Holland tussen 2008 en 2025 jaarlijks de meeste gediplomeerden hbo techniek aflevert. Ook Noord-Brabant, Noord-Holland en Gelderland zijn provincies waarin jaarlijks veel hbo bachelors een diploma in de techniek behalen. In Flevoland, Zeeland en Drenthe studeren tussen 2008 en 2025 jaarlijks de minste hbo bachelors af met een diploma techniek. 
Figuur 3.14

Relatief aantal afgestudeerden hbo techniek, 2008-2025 (geïndexeerd op 2008=100)

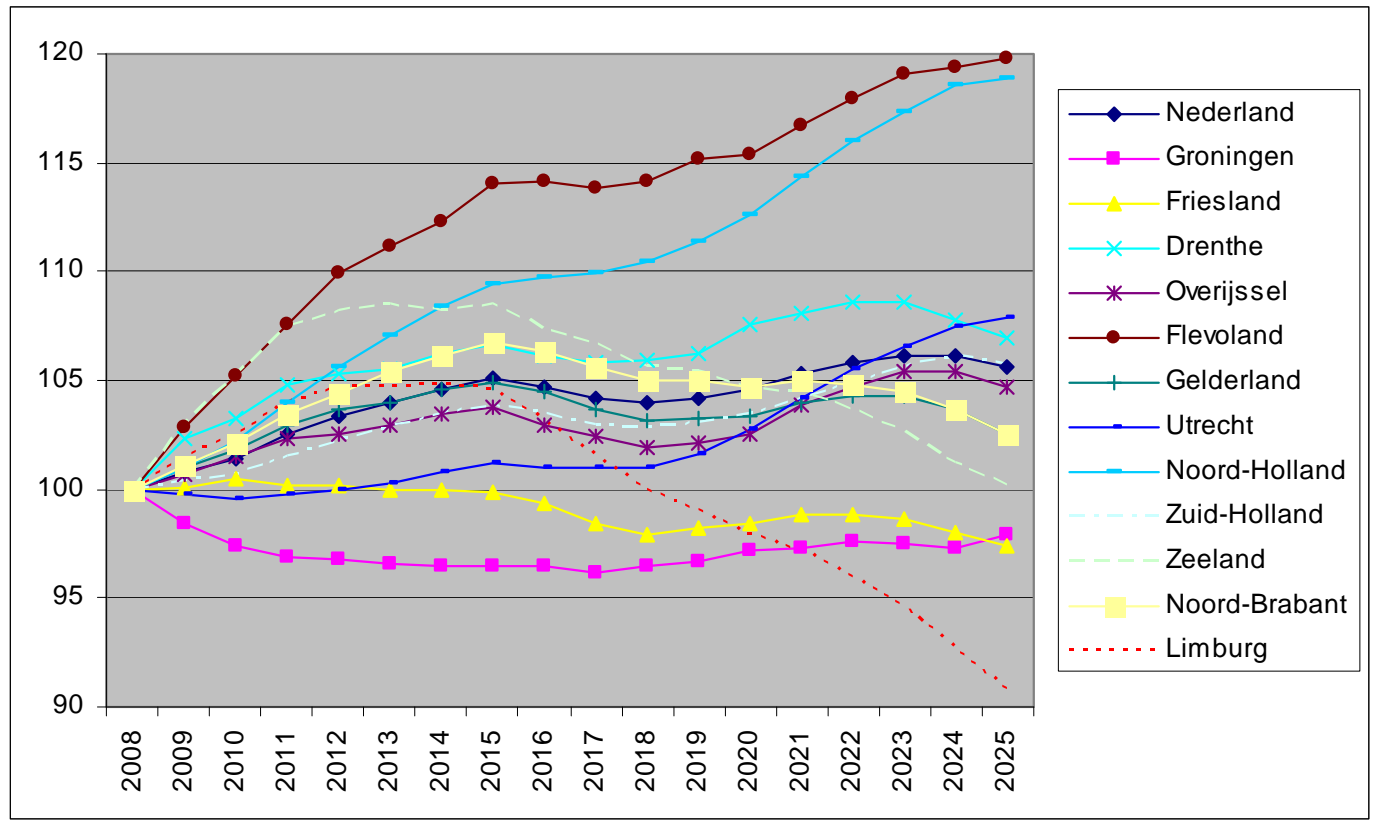

Uit figuur 3.14 kan geconcludeerd worden dat de verwachte trend tot 2025 voor het totale aantal afgestudeerde personen met een afgeronde technische hbo-opleiding sterk kan verschillen tussen provincies. Flevoland en Noord-Holland laten sterke stijgingen zien, terwijl er in Limburg relatief steeds minder afgestudeerde hbotechnici verwacht worden. Voor Nederland als geheel en voor de meeste provincies wordt er een toename van het aantal gediplomeerden hbo techniek verwacht met bijna $6 \%$-punt. Uitzonderingen zijn de provincies Groningen en Friesland, terwijl Limburg na een aanvankelijk stijging een dramatische daling laat zien vanaf 2015. 
Figuur 3.15

Absoluut aantal afgestudeerde mannen hbo techniek, 2008-2025

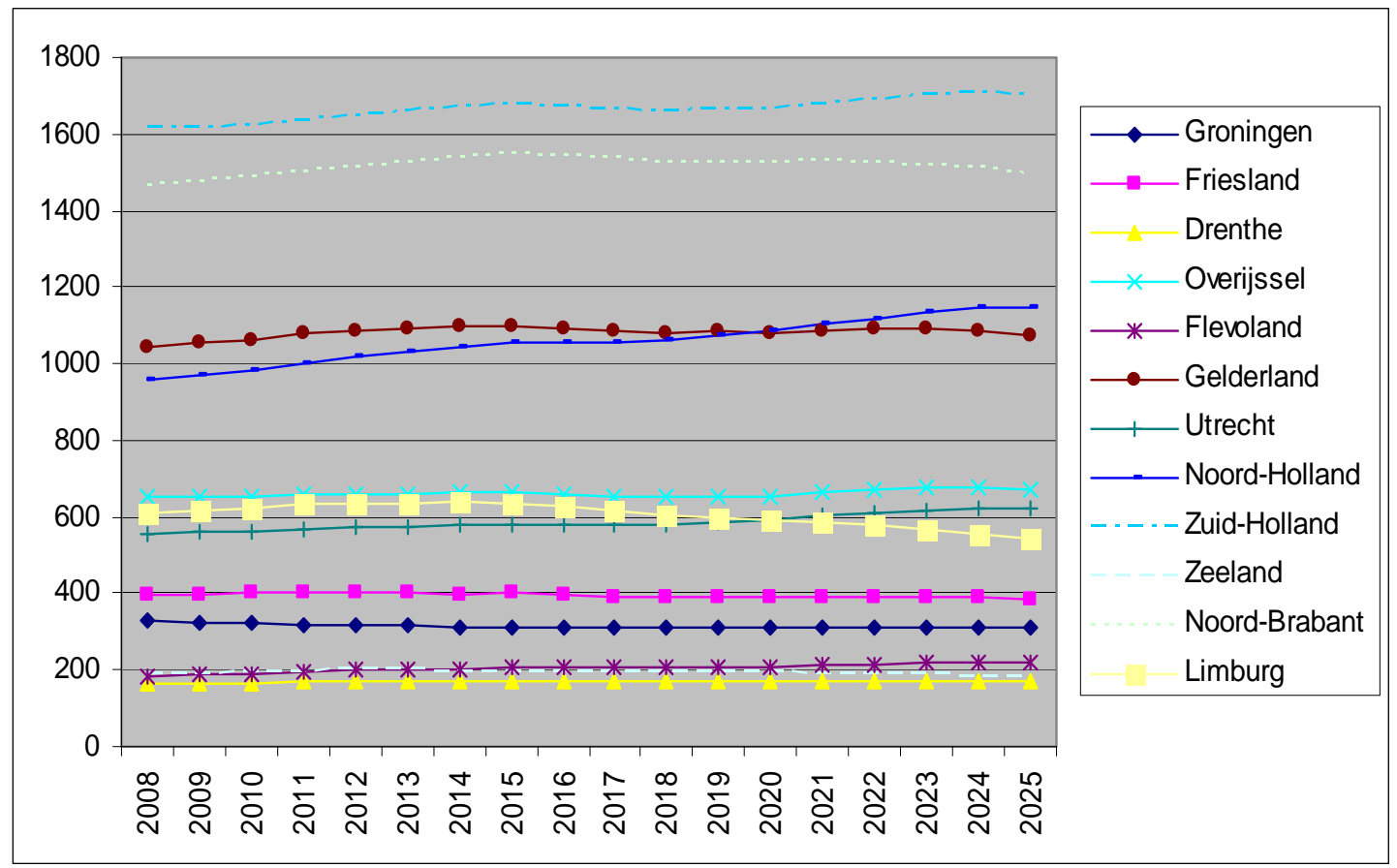

Figuur 3.15 geeft per provincie de prognoses weer voor het aantal afgestudeerde mannen hbo techniek voor de periode 2008-2025. Jaarlijks wonen de meeste mannelijke gediplomeerden hbo techniek in Zuid-Holland. Ook in Noord-Brabant wonen veel gediplomeerde hbo'ers met een technische opleiding. Noord-Holland passeert Gelderland na 2020 en wordt dan de op twee na meest succesvolle provincie wat betreft het aantal mannelijke gediplomeerden hbo techniek.

De geïndexeerde prognoses voor mannelijke gediplomeerden hbo techniek in figuur 3.16 vertonen zoals verwacht grote overeenkomsten met die voor de totale groep gediplomeerden hbo techniek in figuur 3.14. Dit aangezien laatstgenoemde groep grotendeels bestaat uit mannen. 
Figuur 3.16

Relatief aantal afgestudeerde mannen hbo techniek, 2008-2025 (geïndexeerd op 2008=100)

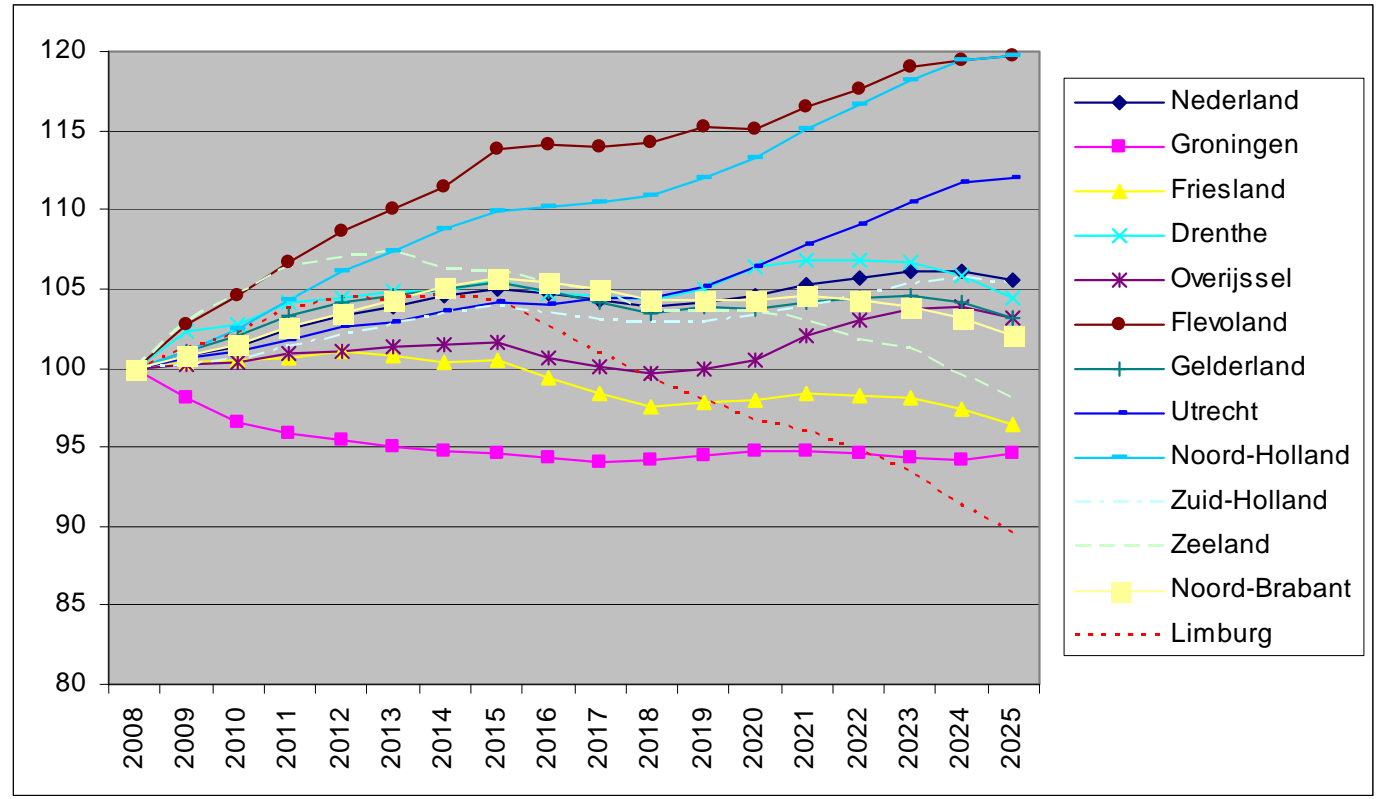

Figuur 3.17

Absoluut aantal afgestudeerde vrouwen hbo techniek, 2008-2025

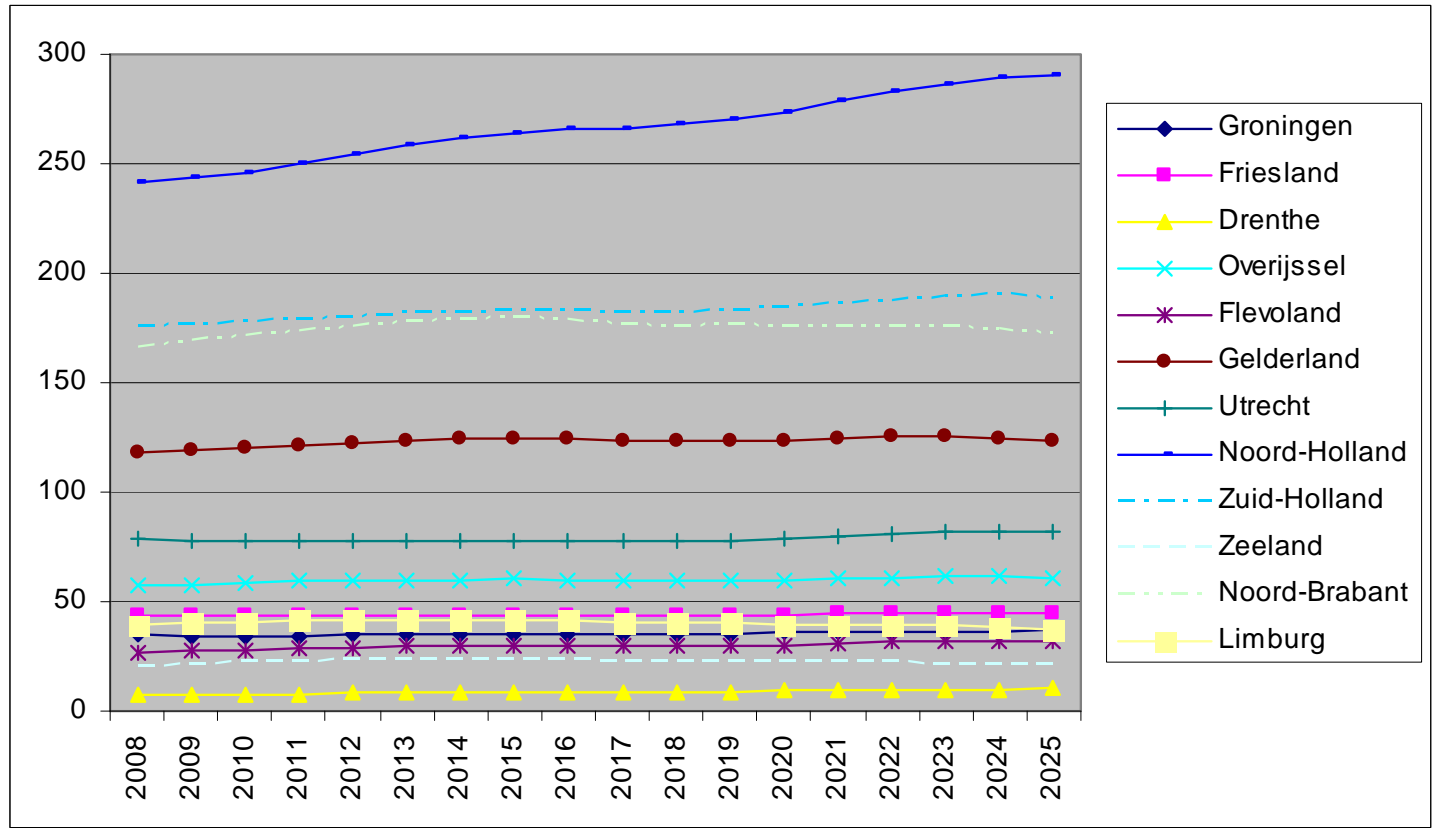

Figuur 3.17 laat duidelijk zien dat Noord-Holland de provincie is die jaarlijks de meeste vrouwelijke gediplomeerden hbo techniek heeft. Dit in tegenstelling tot mannelijke gediplomeerden hbo-techniek, die voornamelijk in Zuid-Holland of Noord-Brabant terug te vinden zijn.

In figuur 3.18 lijkt Drenthe het in de prognoses op het eerste oog goed te doen qua toename van het aantal afgestudeerde vrouwen met een technische opleiding in vergelijking met het basisjaar. Uit figuur 3.17 blijkt echter dat deze toename absoluut gezien van weinig betekenis is. Het aantal afgestudeerde vrouwen met een opleiding hbo techniek in Nederland zal de eerste jaren toenemen, waarna er een lichte daling ingezet zal worden 
gevolgd door opnieuw een stijging vanaf 2018. Met uitzondering van Limburg is het aantal gediplomeerde vrouwen hbo techniek in 2025 in alle provincies toegenomen in vergelijking met het basisjaar.

Figuur 3.18

Relatief aantal afgestudeerde vrouwen hbo techniek, 2008-2025 (geïndexeerd op 2008=100)

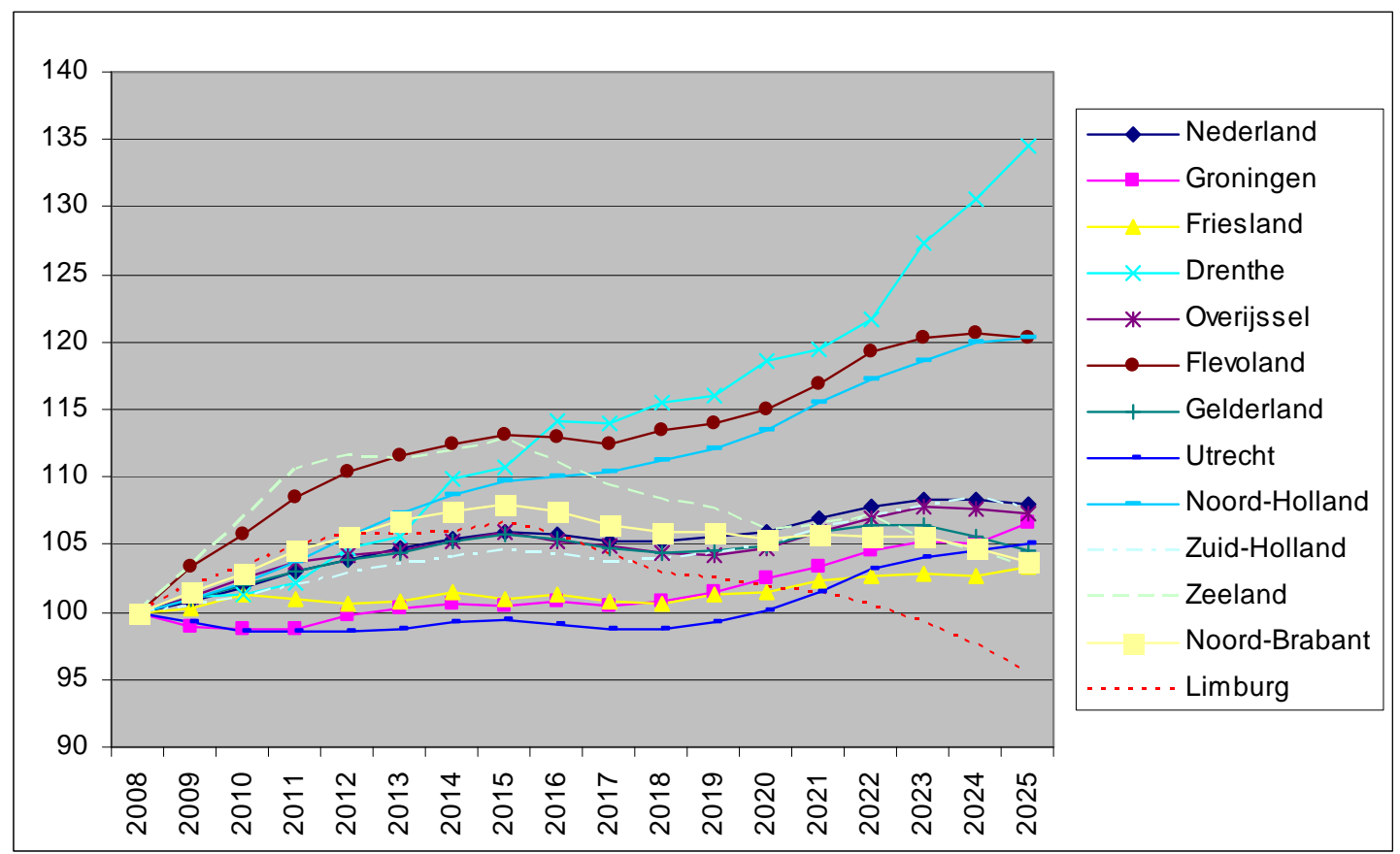

Figuur 3.19

Absoluut aantal afgestudeerde autochtonen hbo techniek, 2008-2025

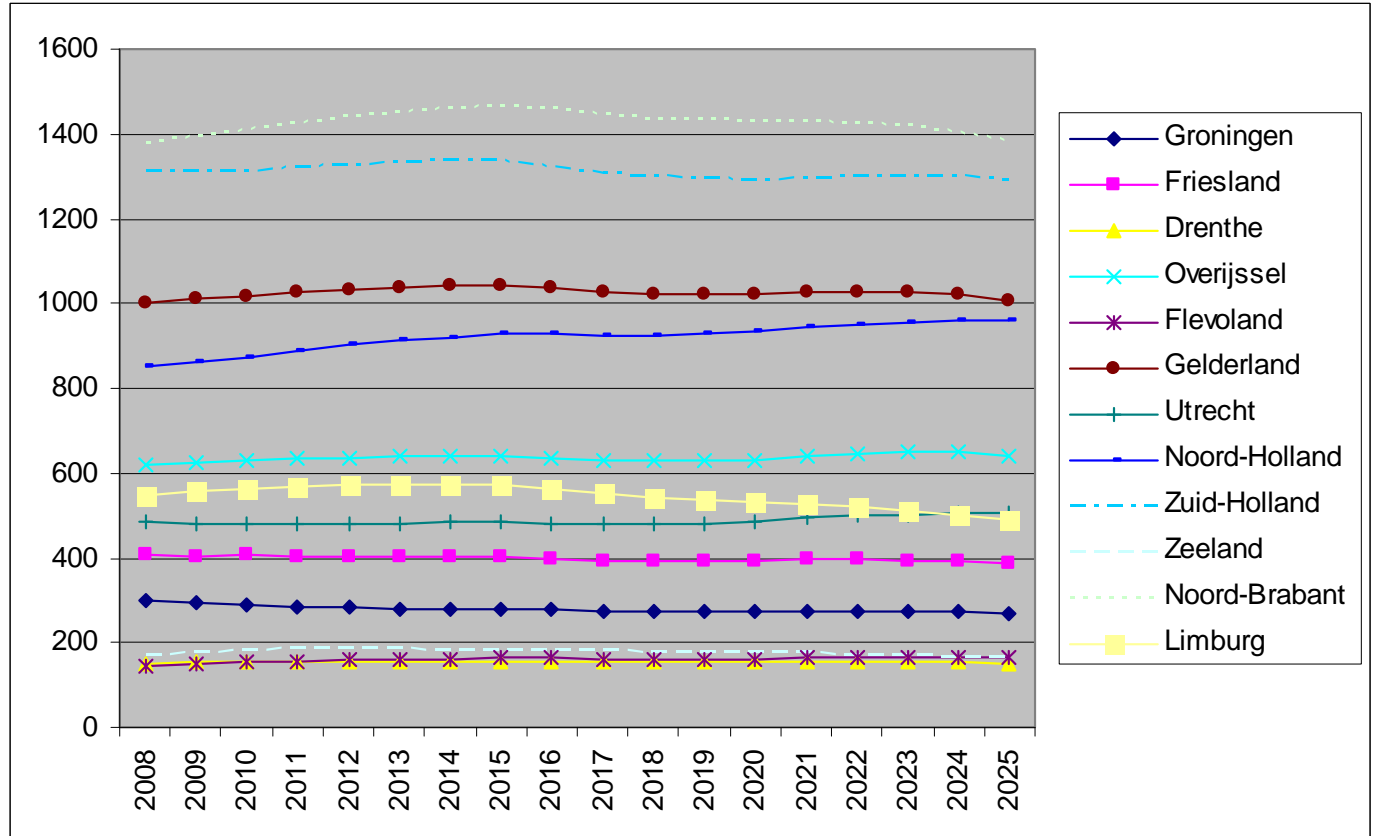

Volgens de prognoses zal Noord-Brabant jaarlijks de meeste autochtone technici met een diploma hbo bachelor hebben. Ook in Zuid-Holland zullen veel hbo'ers een technisch diploma behalen in deze periode. Noord-Holland laat de grootste stijging zien, terwijl in Limburg de grootste daling verwacht wordt. De overige provincies leveren vrijwel elk jaar een zelfde aantal gediplomeerden hbo techniek. 
Figuur 3.20

Relatief aantal afgestudeerde autochtonen hbo techniek, 2008-2025 (geïndexeerd op 2008=100)

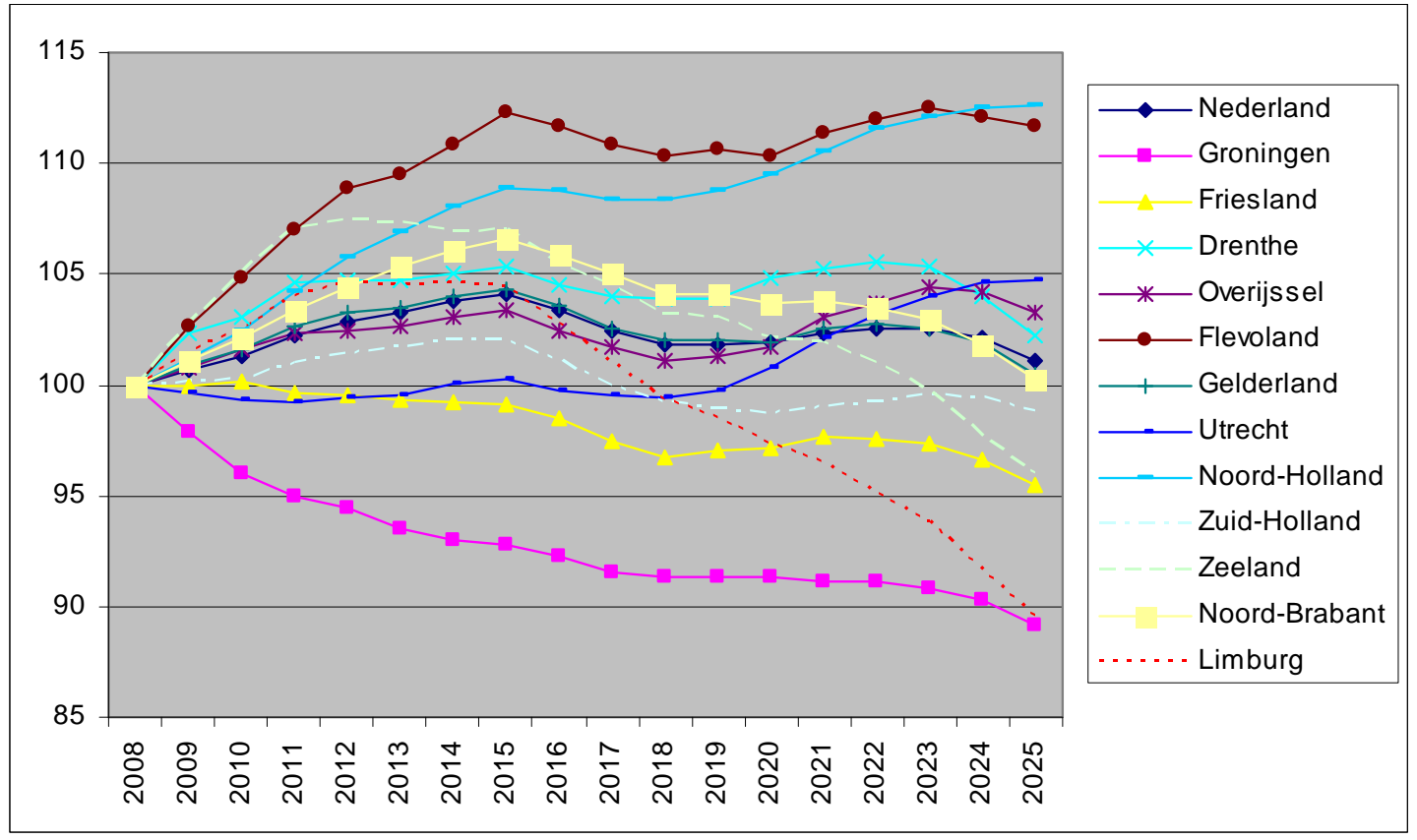

Het totale aantal afgestudeerde autochtonen in hbo techniek zal licht toenemen gedurende de komende jaren, gevolgd door een lichte daling. In Flevoland en Noord-Holland zijn de sterkste stijgingen te verwachten van de groep autochtone gediplomeerden hbo techniek. Groningen en Limburg zullen daarentegen veel minder autochtone hbo technici afleveren. 
Figuur 3.21

Absoluut aantal afgestudeerde westerse allochtonen hbo techniek, 2008-2025

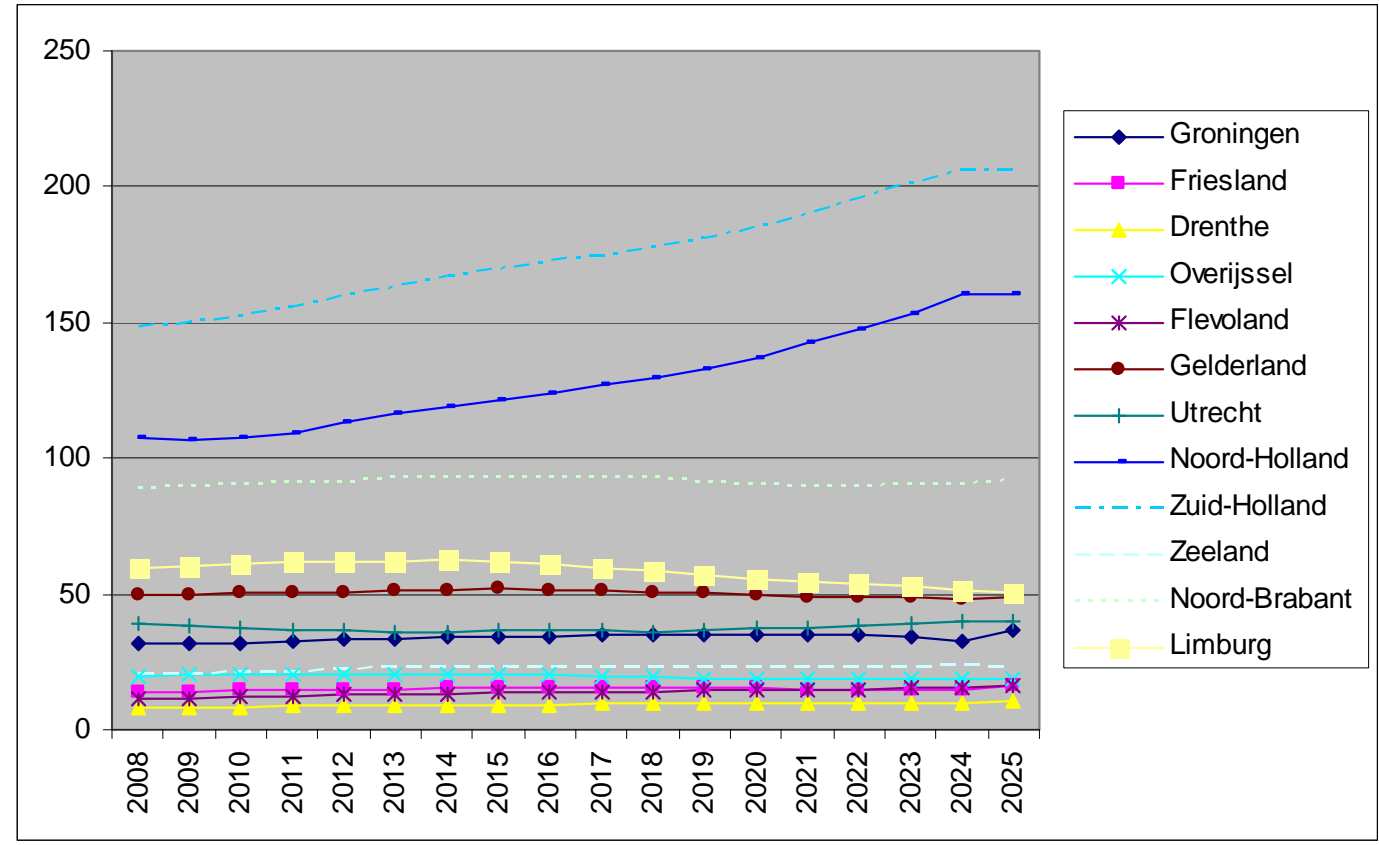

Figuur 3.21 presenteert de prognoses voor westerse allochtone gediplomeerden hbo techniek. In zowel ZuidHolland als ook Noord-Holland wordt een stijging voorzien van het aantal westerse allochtonen met een hbodiploma in de technische richting behaalt. In Limburg daalt het aantal westerse allochtone gediplomeerden hbo techniek iets. In de overige provincies blijft het aantal westerse allochtonen hbo techniek volgens de prognoses min of meer gelijk of stijgt het licht. 
Figuur 3.22

Relatief aantal afgestudeerde westerse allochtonen hbo techniek, 2008-2025 (geïndexeerd op 2008=100)

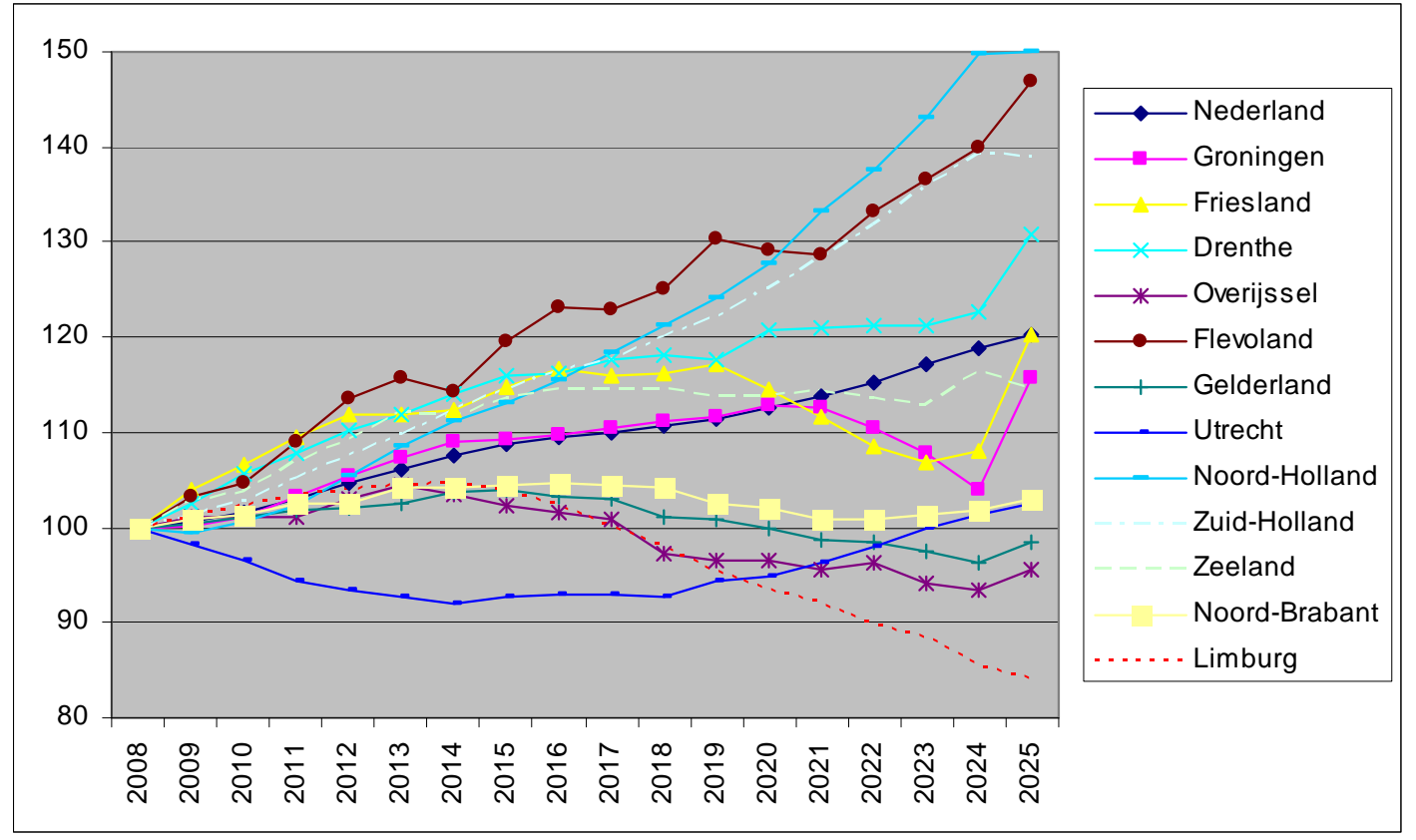

In Noord-Holland, Flevoland en Zuid-Holland stijgt het aantal westerse allochtone afgestudeerden hbo techniek de komende jaren het meest. In Utrecht worden eerst minder westerse allochtonen met een technische hboopleiding verwacht. Vanaf 2018 wordt echter weer een relatief sterke stijging voorzien. Limburg zal de komende jaren steeds minder westerse allochtonen met een technische hbo-opleiding voortbrengen.

Figuur 3.23

Absoluut aantal afgestudeerde niet-westerse allochtonen hbo techniek, 2008-2025

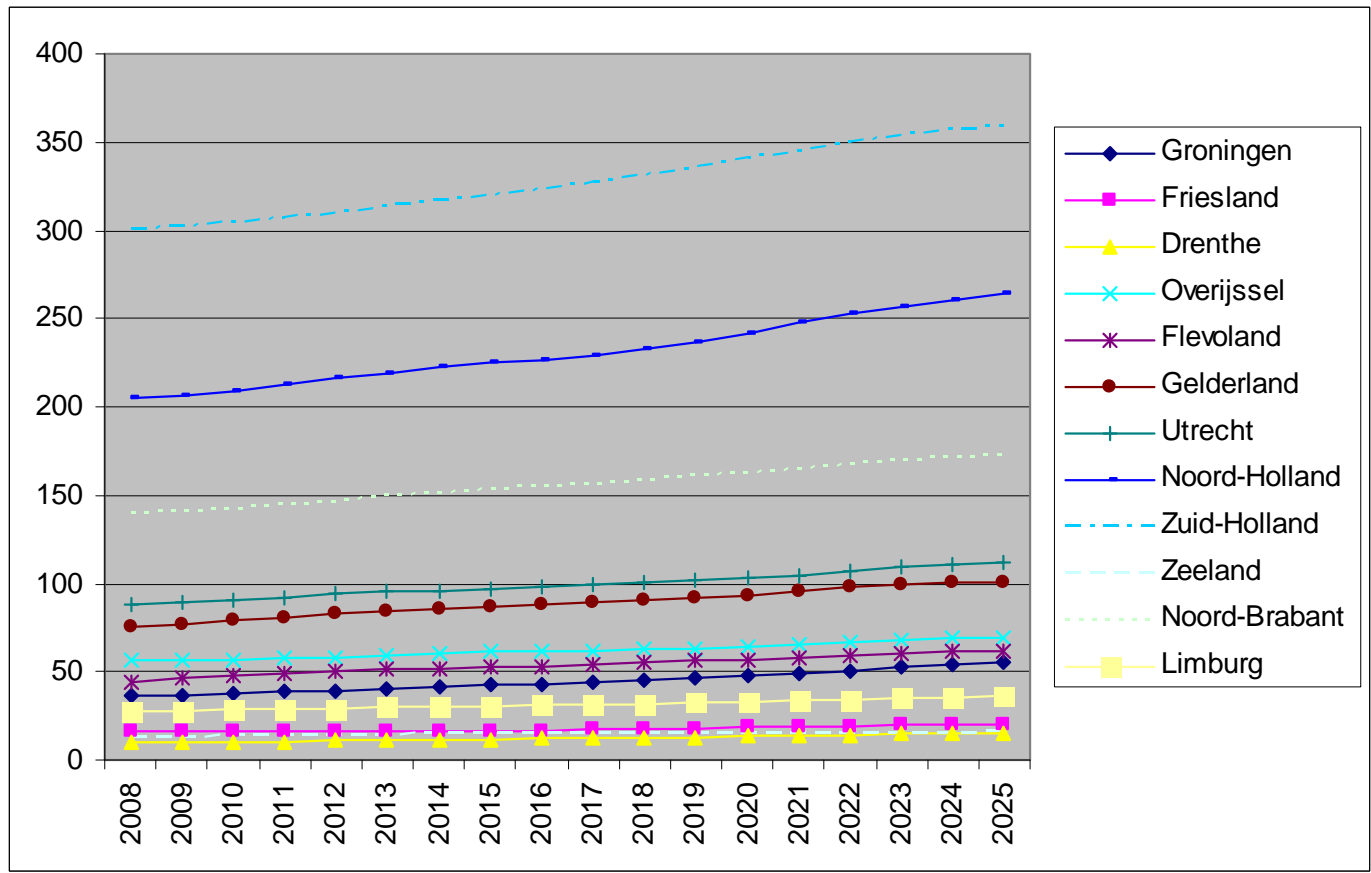

Figuur 3.23 geeft de regionale prognoses weer voor de groep niet-westerse allochtone gediplomeerden hbo techniek. Met betrekking tot de prognoses voor het aantal niet-westerse allochtonen kunnen vergelijkbare 
conclusies getrokken worden als bij westerse allochtonen. Ook hier wordt er in Zuid-Holland en Noord-Holland namelijk een stijging verwacht van het aantal afgestudeerde hbo technici van niet-westerse herkomst. De overige provincies laten daarbij ook een lichte stijging zien. 
Figuur 3.24

Relatief aantal afgestudeerde niet-westerse allochtonen hbo techniek, 2008-2025 (geïndexeerd op 2008=100)

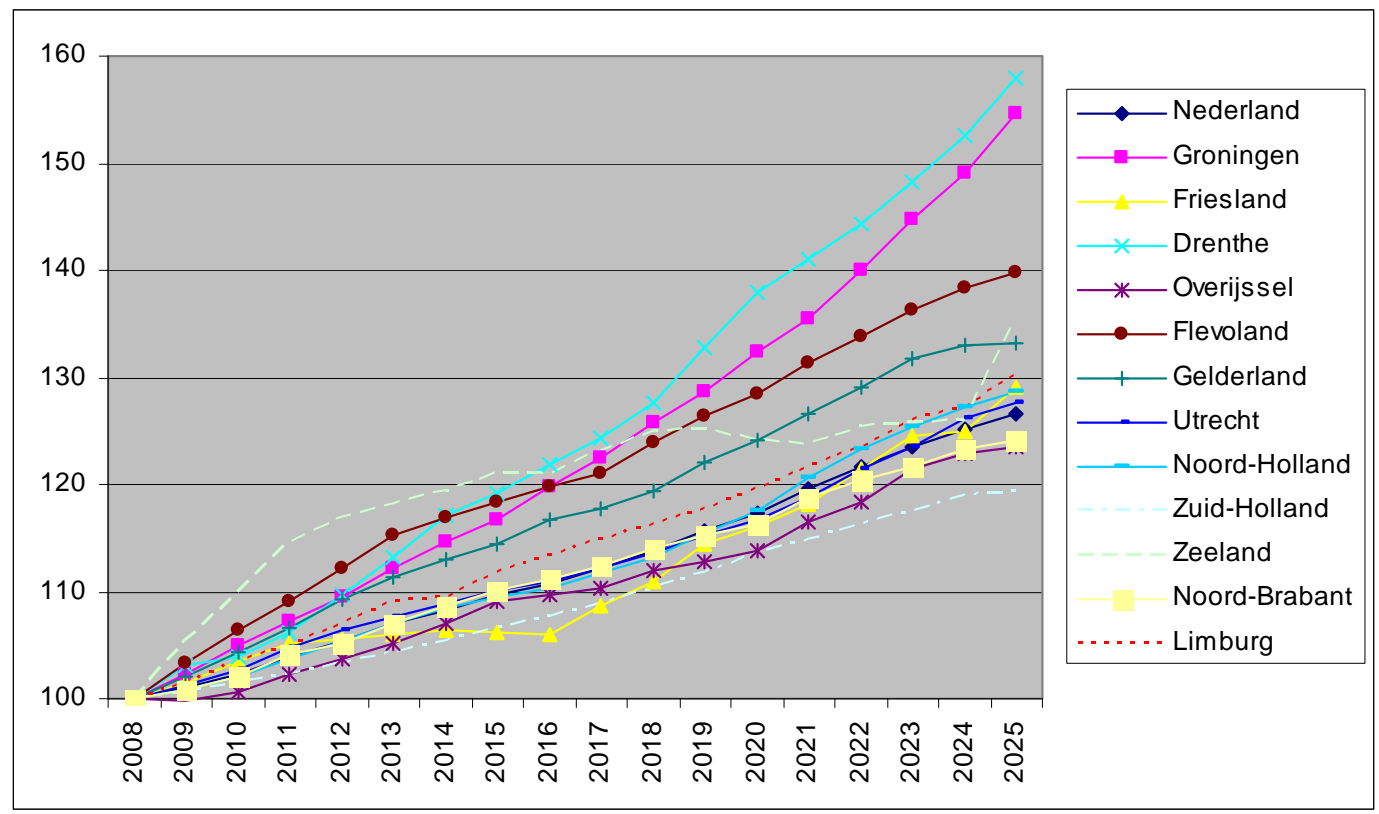

In elke provincie neemt het aantal personen van niet-westerse herkomst tussen 2008 en 2025 toe. De prognoses voor Drenthe en Groningen laten zelfs stijgingen zien van meer dan 50 \%-punt ten opzichte van het basisjaar. Absoluut gezien zijn deze ontwikkelingen echter niet schokkend te noemen.

\subsection{Wo-gediplomeerden}

Figuur 3.25

Absoluut aantal afgestudeerden wo techniek , 2008-2025

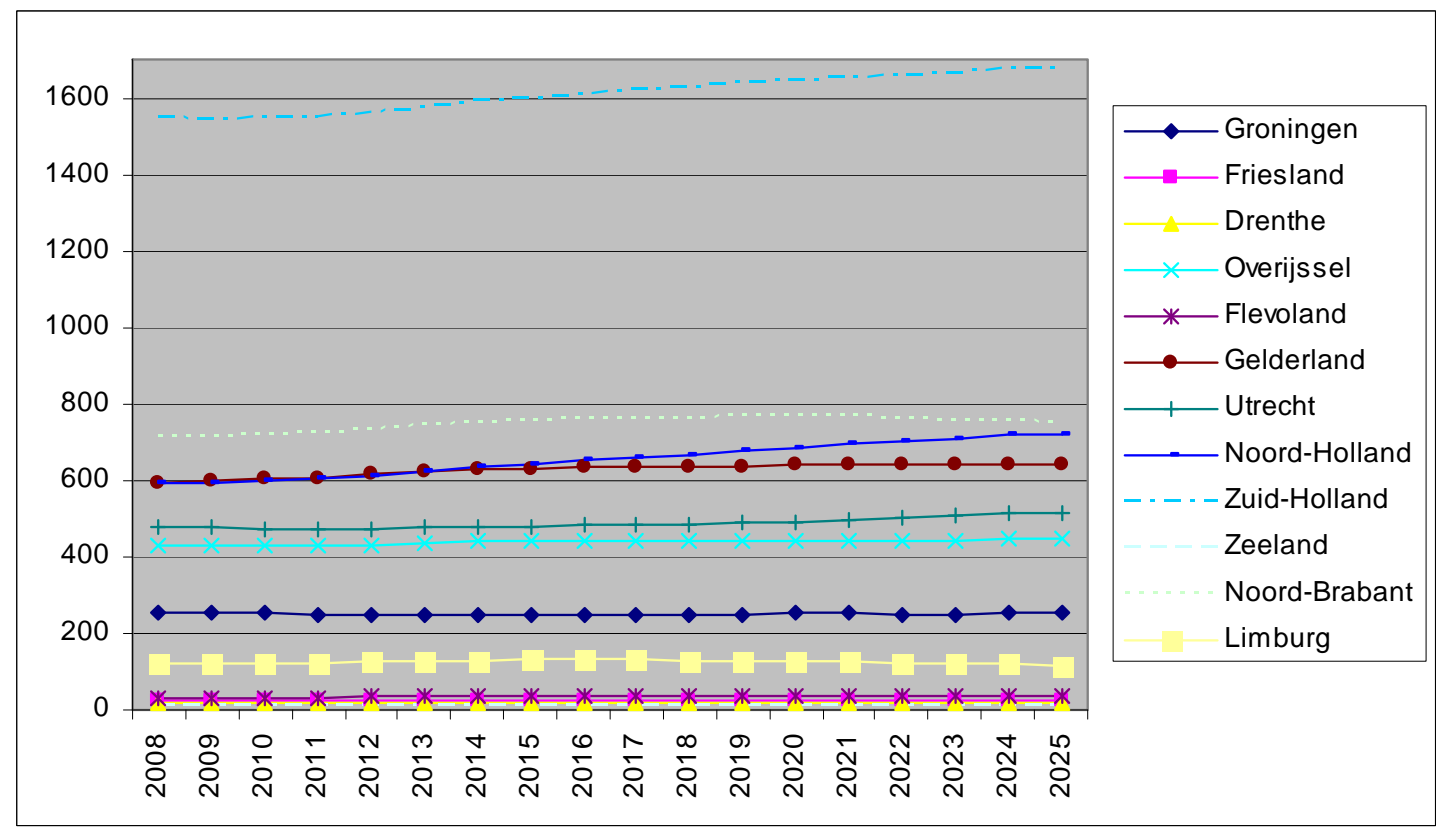

Figuur 3.25 laat zien dat Zuid-Holland elk jaar het hoogste totale aantal gediplomeerden wo techniek heeft. Op behoorlijke afstand volgen Noord-Brabant, Noord-Holland, Gelderland, Utrecht, en Overijssel. Daar staat 
tegenover dat er ook enkele provincies zijn die nauwelijks gediplomeerden wo techniek hebben. In het algemeen kan gesteld worden dat er weinig fluctuaties zijn in het aantal afgestudeerden wo techniek per provincie.

De prognoses voor de ontwikkeling van het totale aantal gediplomeerden wo techniek in Nederland in figuur 3.26 laten een gestage toename zien van deze groep tot bijna 9 \%-punt in 2025. Het totale aantal gediplomeerden wo techniek stijgt de komende jaren het sterkste in Flevoland. Gezien de kleine bijbehorende absolute aantallen van Flevoland en enkele andere provincies in figuur 3.25 dient er echter enige terughoudendheid in acht genomen te worden bij de interpretatie van deze relatieve cijfers. Noord-Holland stijgt in eerste instantie geleidelijker, maar bereikt tegen het einde van de prognoses een toename van meer dan 20 \%-punt. De provincie met het grootste aantal gediplomeerden wo techniek, Zuid-Holland, laat een gestage stijging zien. Groningen en vooral Limburg zijn de enige provincies waarin het aantal gediplomeerden wo techniek lager zal zijn in 2025 dan in 2008.

Figuur 3.26

Relatief aantal afgestudeerden wo techniek, 2008-2025 (geïndexeerd op 2008=100)

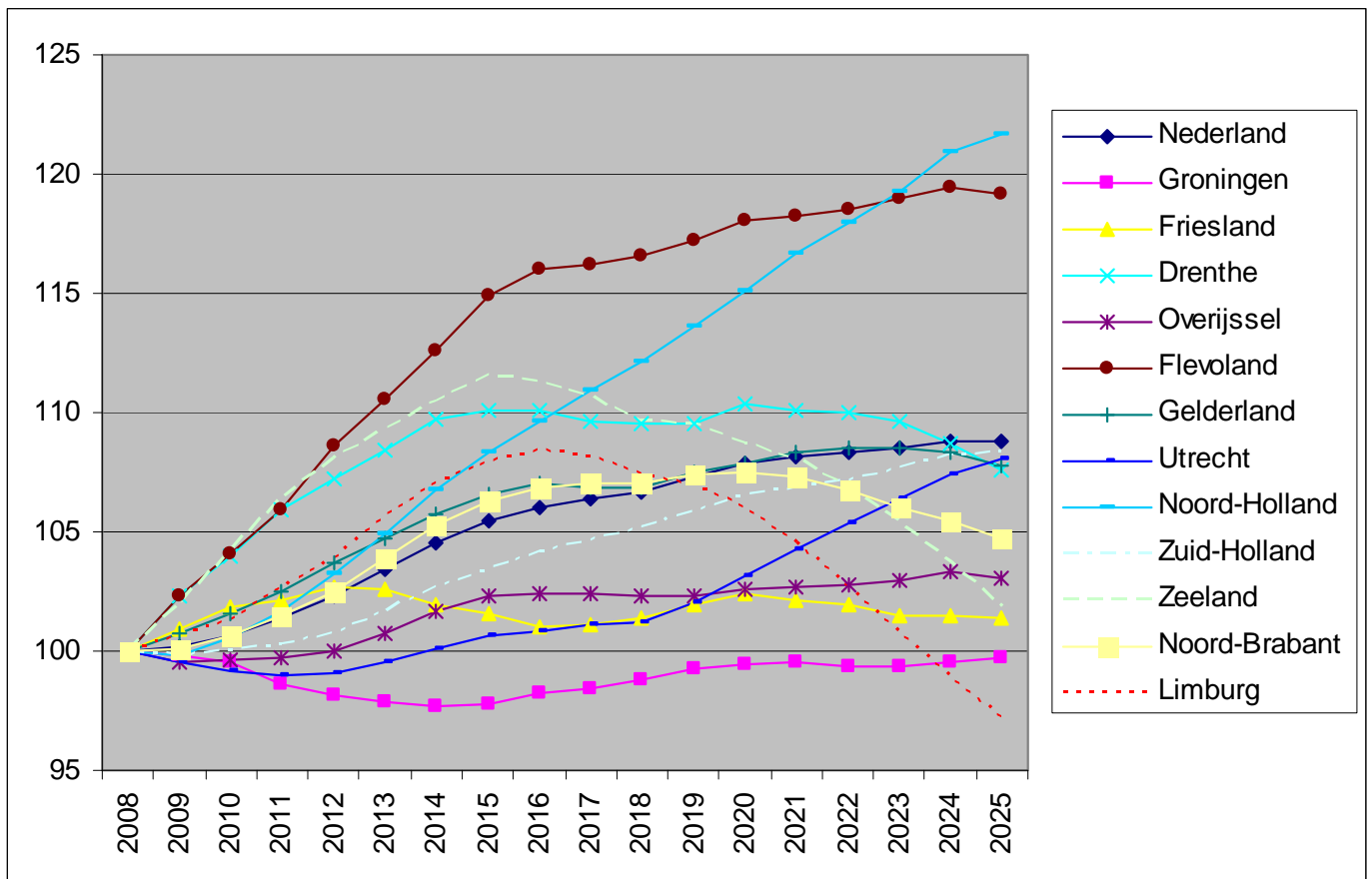


Figuur 3.27

Absoluut aantal afgestudeerde mannen wo techniek, 2008-2025

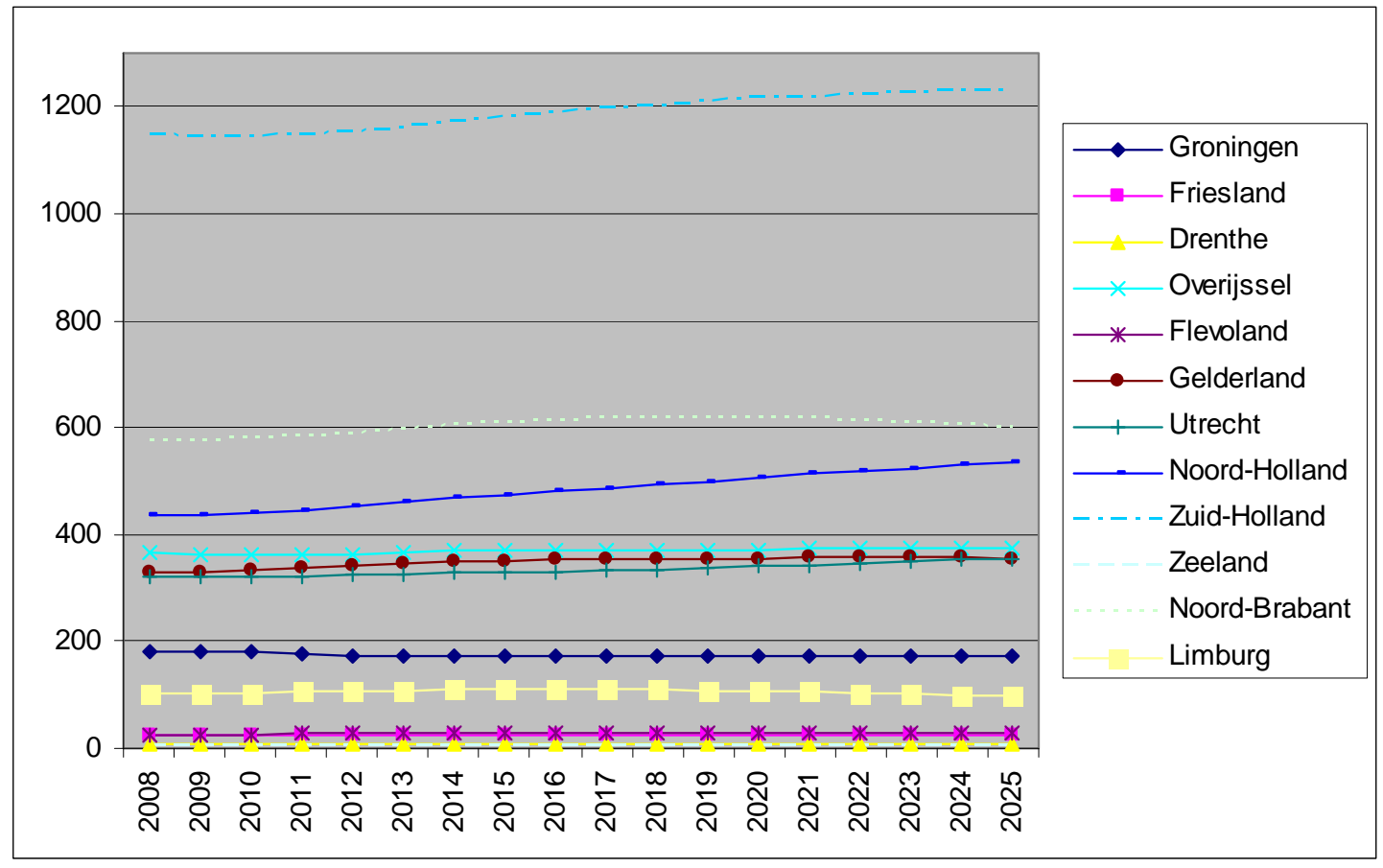

De meeste mannelijke gediplomeerden wo techniek zijn woonachtig in Zuid-Holland, zoals blijkt uit de prognoses in figuur 3.27. Naast Zuid-Holland leveren ook achtereenvolgens Noord-Brabant en Noord-Holland nog een groot aantal mannelijke gediplomeerden wo techniek.

In figuur 3.28 is gekeken naar de toename van het aantal gediplomeerden per provincie, waarbij vooral Flevoland een flinke toename laat zien. Uit de bijbehorende aantallen blijkt echter dat het slechts gaat om een toename van 25 naar 30 mannelijke gediplomeerden wo techniek. Interessanter is daarom de relatieve toename van mannelijke gediplomeerden wo techniek in Noord-Holland in figuur 3.28. Vergeleken met het basisjaar, valt er in deze provincie een toename te verwachten van meer dan $22 \%$-punt in 2025. Absoluut gezien gaat het hier om een stijging van circa 100 personen. Groningen en Limburg zijn de enige provincies waarin het aantal mannelijke gediplomeerden wo techniek zal afnemen. Het aantal mannelijke gediplomeerden wo techniek in geheel Nederland zal volgens de prognoses gestaag toenemen met iets meer dan 8 \%-punt in 2025 in vergelijking met 2008 . 
Figuur 3.28

Relatief aantal afgestudeerde mannen wo techniek, 2008-2025 (geïndexeerd op 2008=100)

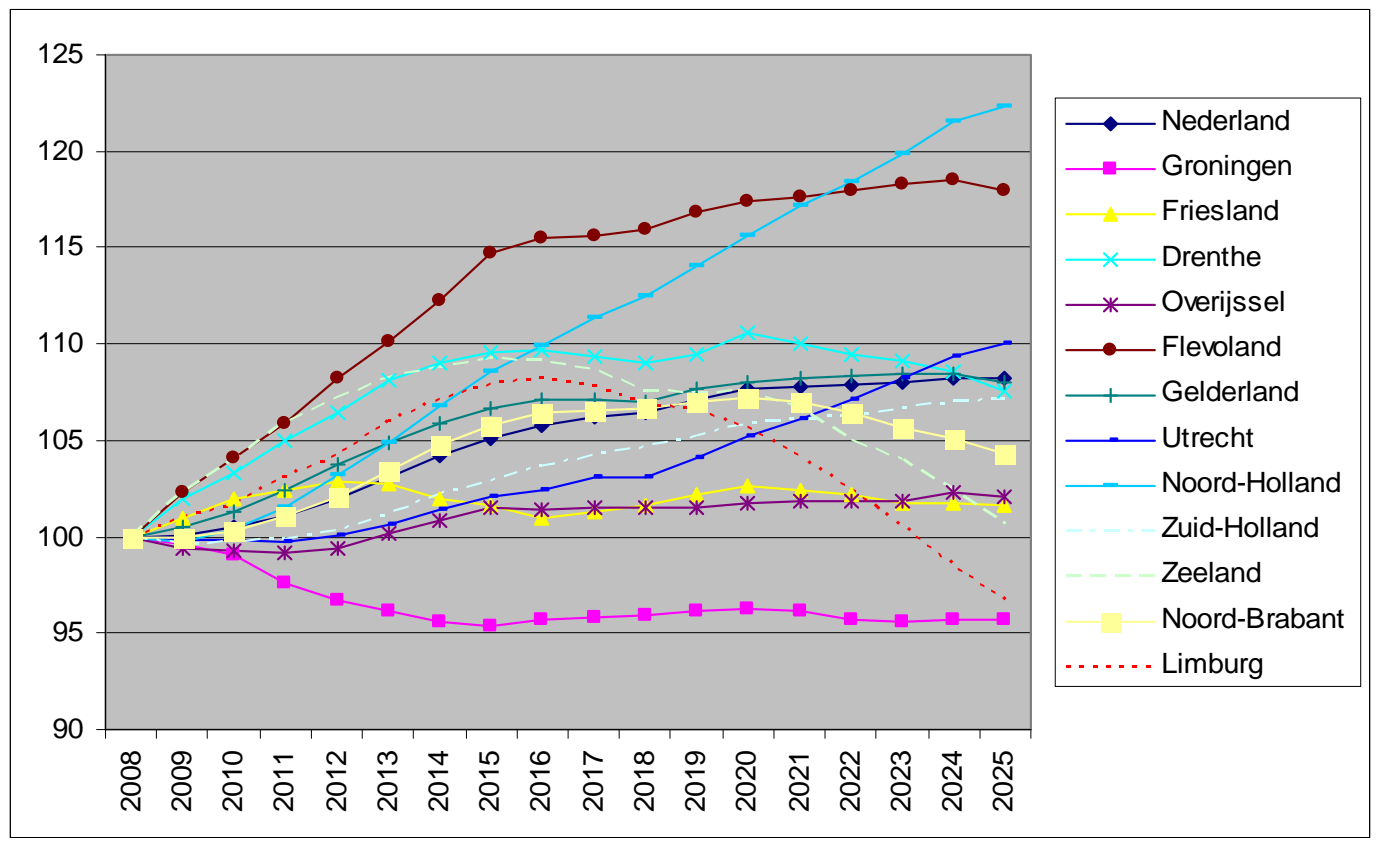

Figuur 3.29

Absoluut aantal afgestudeerde vrouwen wo techniek, 2008-2025

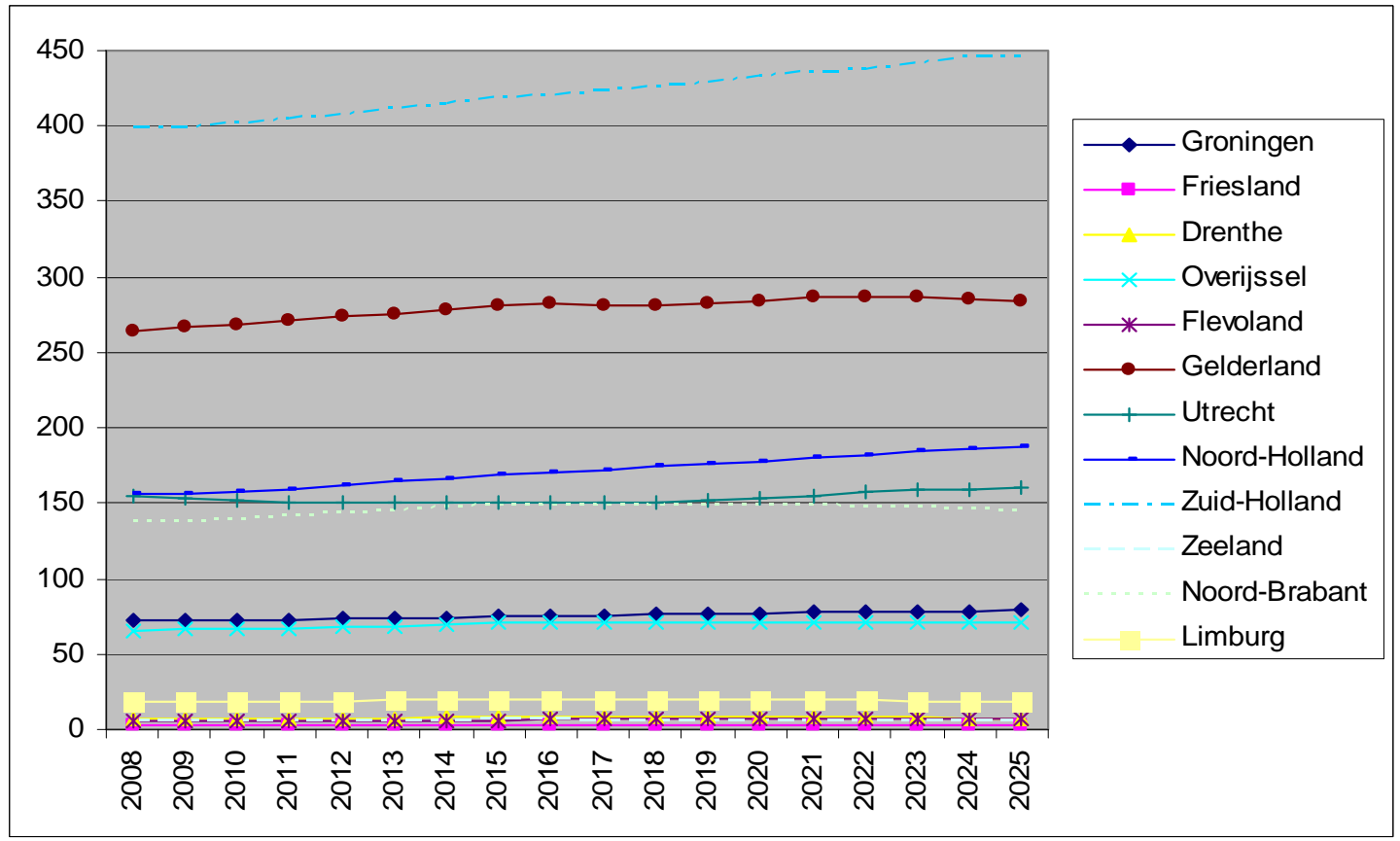

Figuur 3.29 geeft de prognoses weer voor het absolute aantal vrouwen met een wo-diploma techniek. Evenals bij de prognoses voor mannen, blijken vrouwelijke gediplomeerden wo techniek doorgaans in Zuid-Holland te wonen. Ook Gelderland levert veel vrouwelijke gediplomeerden wo techniek.

Uit figuur 3.30 valt de relatieve ontwikkeling van de populatie vrouwelijke gediplomeerden wo techniek af te lezen. De gemiddelde cijfers voor Nederland geven aan dat er de komende jaren meer vrouwen bij zullen komen met een wo-diploma in een technische richting. In 2025 is dit aantal gestegen met meer dan $10 \%$-punt ten 
opzichte van 2008. Net als bij mannen laten ook de prognoses voor vrouwelijke gediplomeerden wo techniek in Flevoland een sterke relatieve toename zien. In absolute aantallen blijkt het hier echter om nog geen 10 personen te gaan, waardoor de stijging van $25 \%$-punt in perspectief geplaatst moet worden.

Figuur 3.30

Relatief aantal afgestudeerde vrouwen wo techniek, 2008-2025 (geïndexeerd op 2008=100)

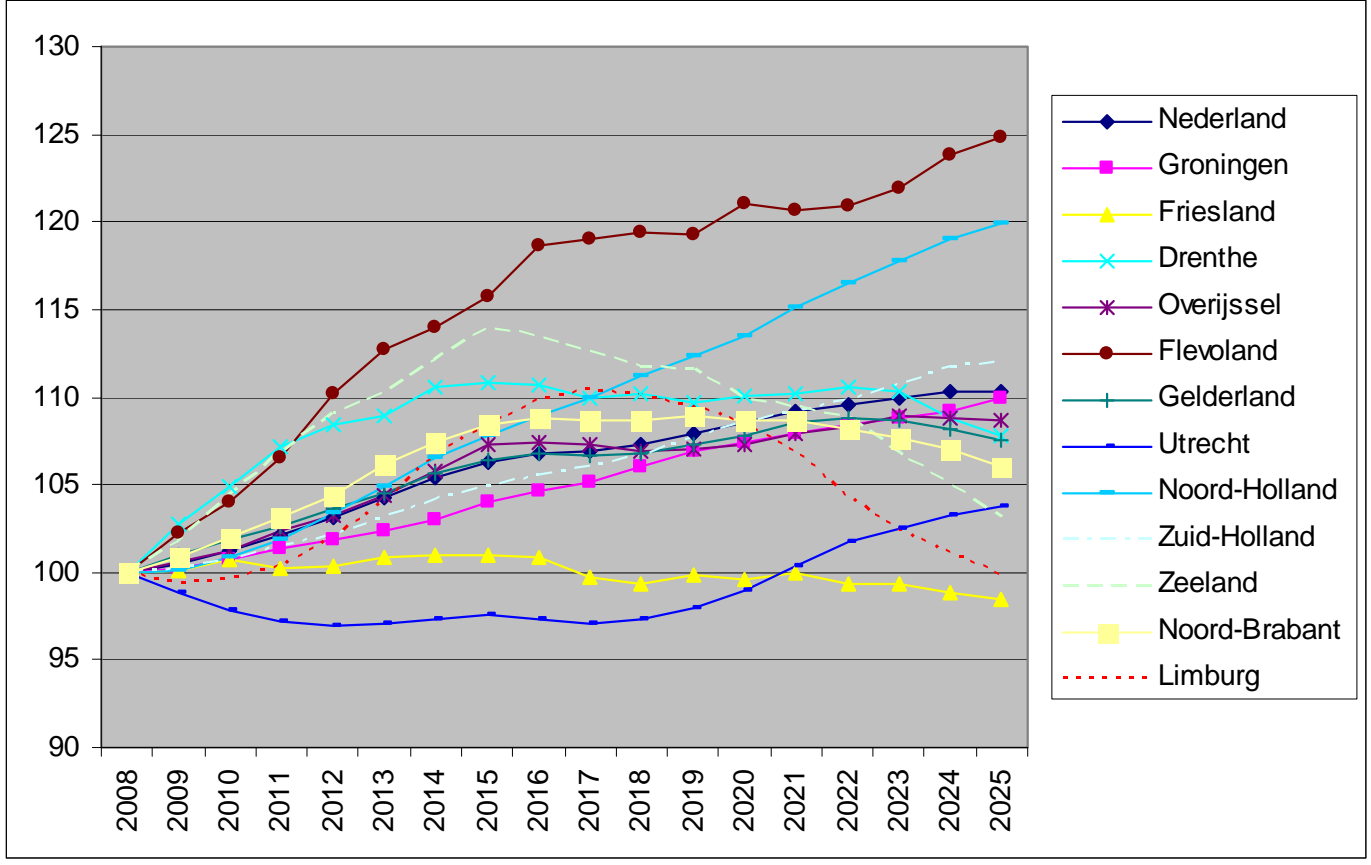


Figuur 3.31

Absoluut aantal afgestudeerde autochtonen wo techniek, 2008-2025

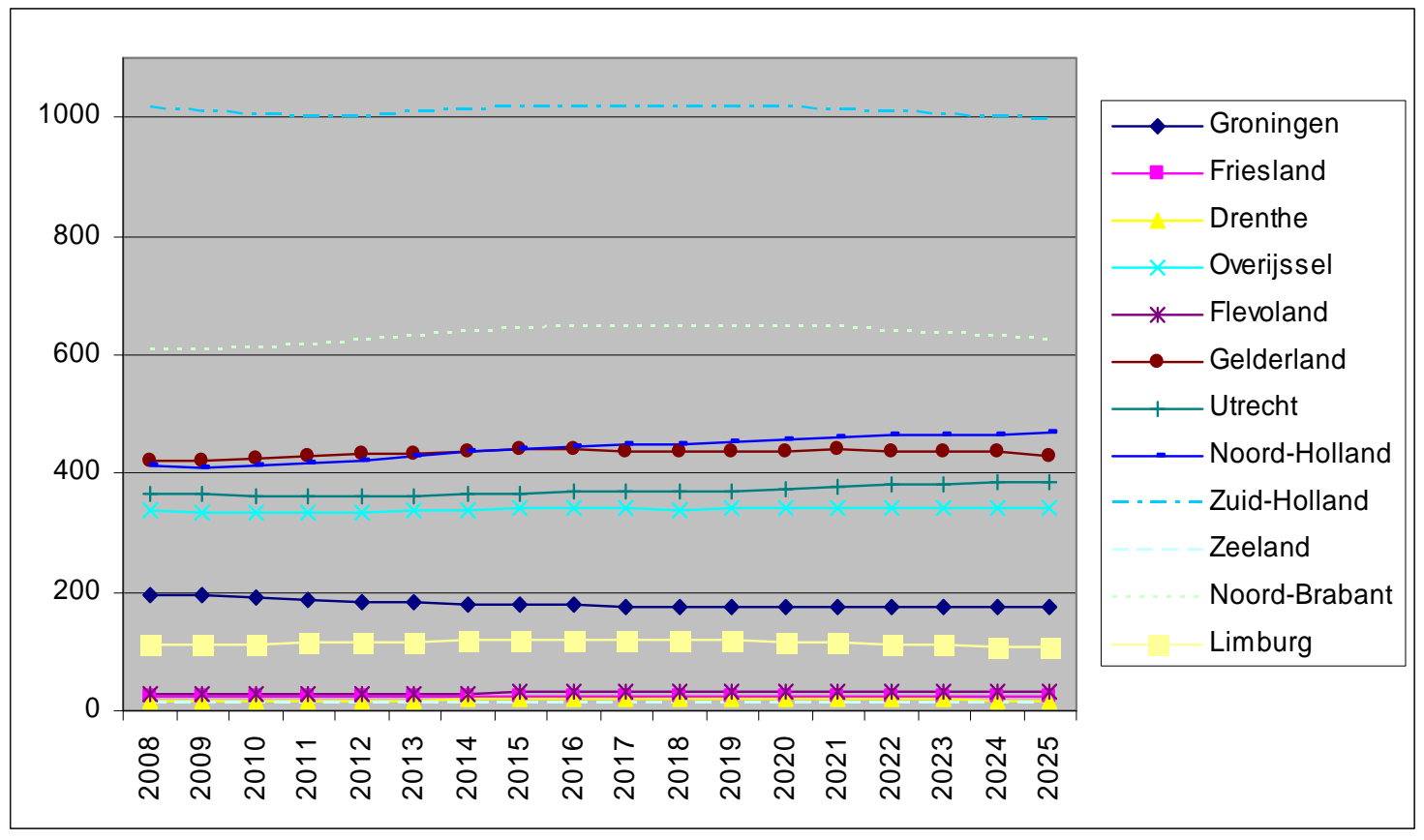

Naast de prognoses voor de totale populatie wo-gediplomeerden techniek en de prognoses voor wogediplomeerden techniek gedifferentieerd naar geslacht presenteren we ook de prognoses voor deze gediplomeerden wo techniek gedifferentieerd naar herkomstgroep.

Figuur 3.31 geeft de prognoses weer voor het aantal autochtone gediplomeerden wo techniek. De figuur vertoont grote overeenkomsten met figuur 3.25 die de prognoses weergeeft voor de totale groep afgestudeerden wo techniek. Zuid-Holland is wederom de provincie die de meeste personen met een wo-diploma techniek levert. 
Figuur 3.32

Relatief aantal afgestudeerde autochtonen wo techniek, 2008-2025 (geïndexeerd op 2008=100)

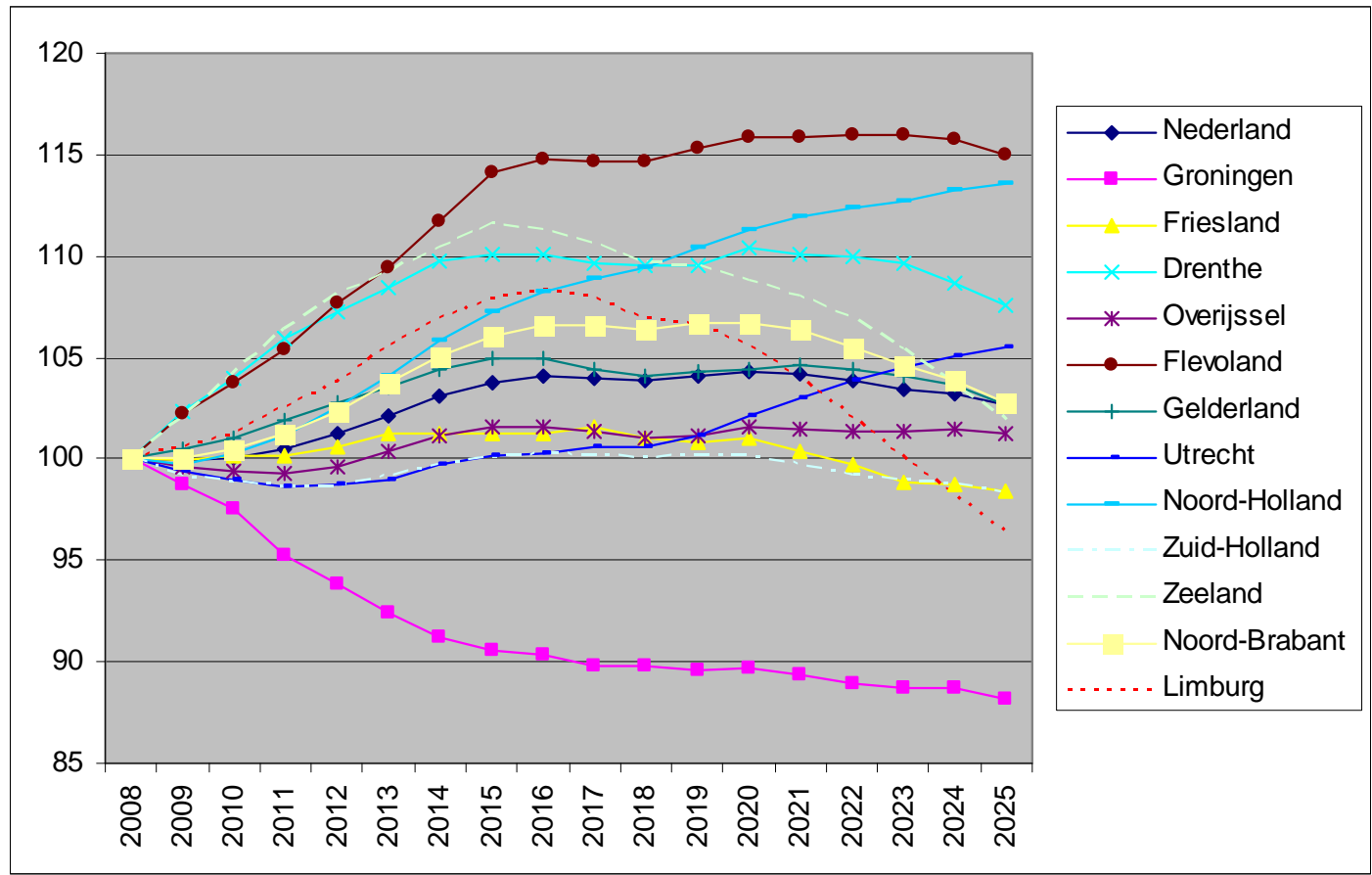

Meest in het oogspringend in figuur 3.32 is de sterke afname van het aantal autochtonen wo techniek in Groningen. Wat echter interessanter is, is dat de trend voor Zuid-Holland volgens de prognoses rond de waarde van het basisjaar schommelt. Dit in tegenstelling tot de prognoses voor de totale groep wo techniek gediplomeerden in Zuid-Holland, die volgens de prognoses in figuur 3.26 gestaag toeneemt tot en met 2025. Dit betekent dat de groei van de gediplomeerden wo techniek in Zuid-Holland enkel door allochtonen gegenereerd wordt. Wat betreft Nederland als geheel kan geconcludeerd worden dat er de eerste jaren een toename van het aantal autochtone afstudeerders wo techniek verwacht wordt, gevolgd door een lichte daling. 
Figuur 3.33

Absoluut aantal afgestudeerde westerse allochtonen wo techniek, 2008-2025

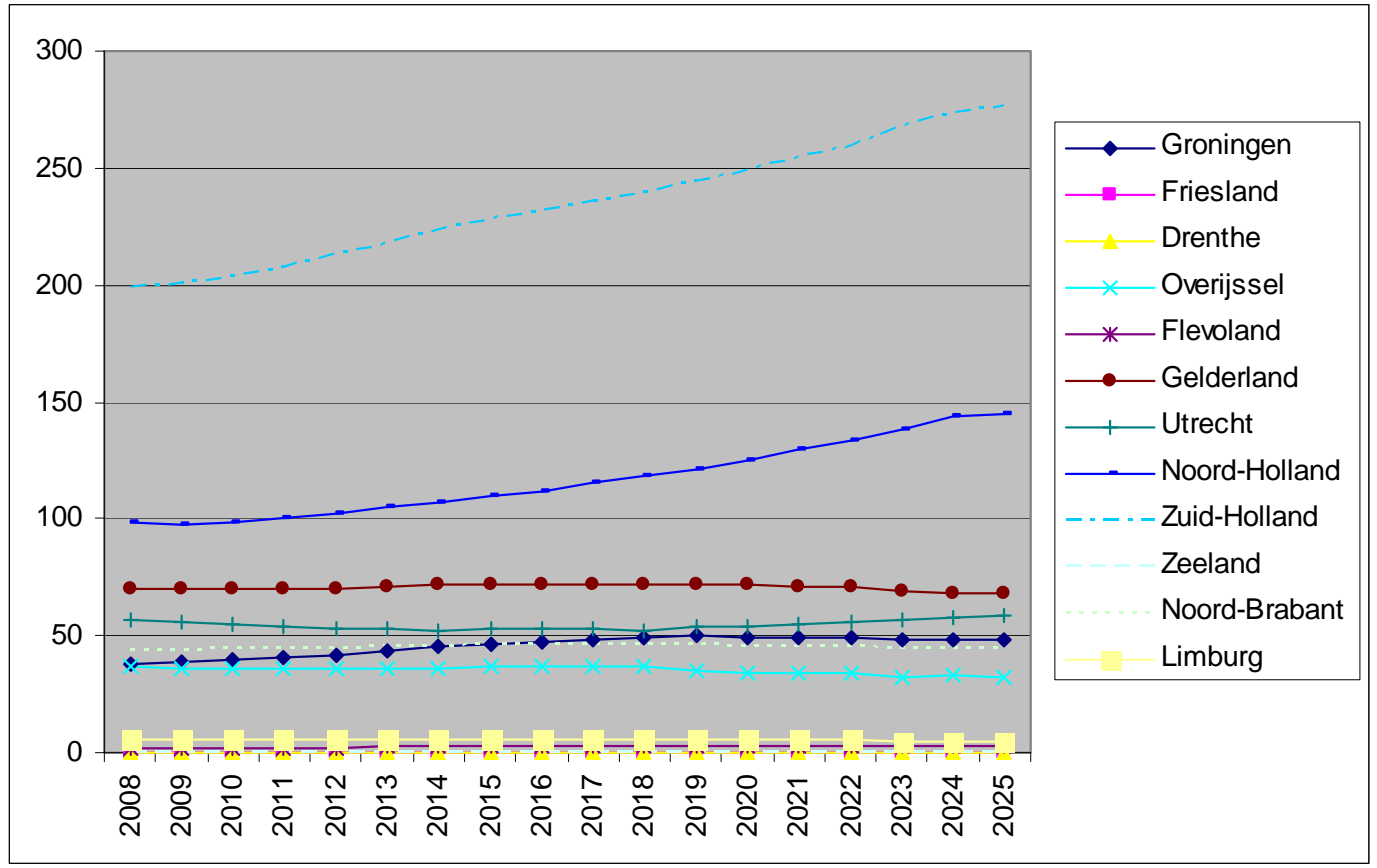

In figuur 3.33 staan de regionale prognoses van westerse allochtone gediplomeerden wo techniek afgebeeld. In Zuid- en Noord-Holland zal het aantal westerse allochtone afgestudeerden wo techniek de komende jaren nog toenemen. In de overige provincies worden op wo-niveau geen noemenswaardige veranderingen voorzien. In het algemeen kan geconcludeerd worden dat er per provincie absoluut gezien maar weinig westerse allochtonen afstuderen. 
Figuur 3.34

Relatief aantal afgestudeerde westerse allochtonen wo techniek, 2008-2025 (2008=100)

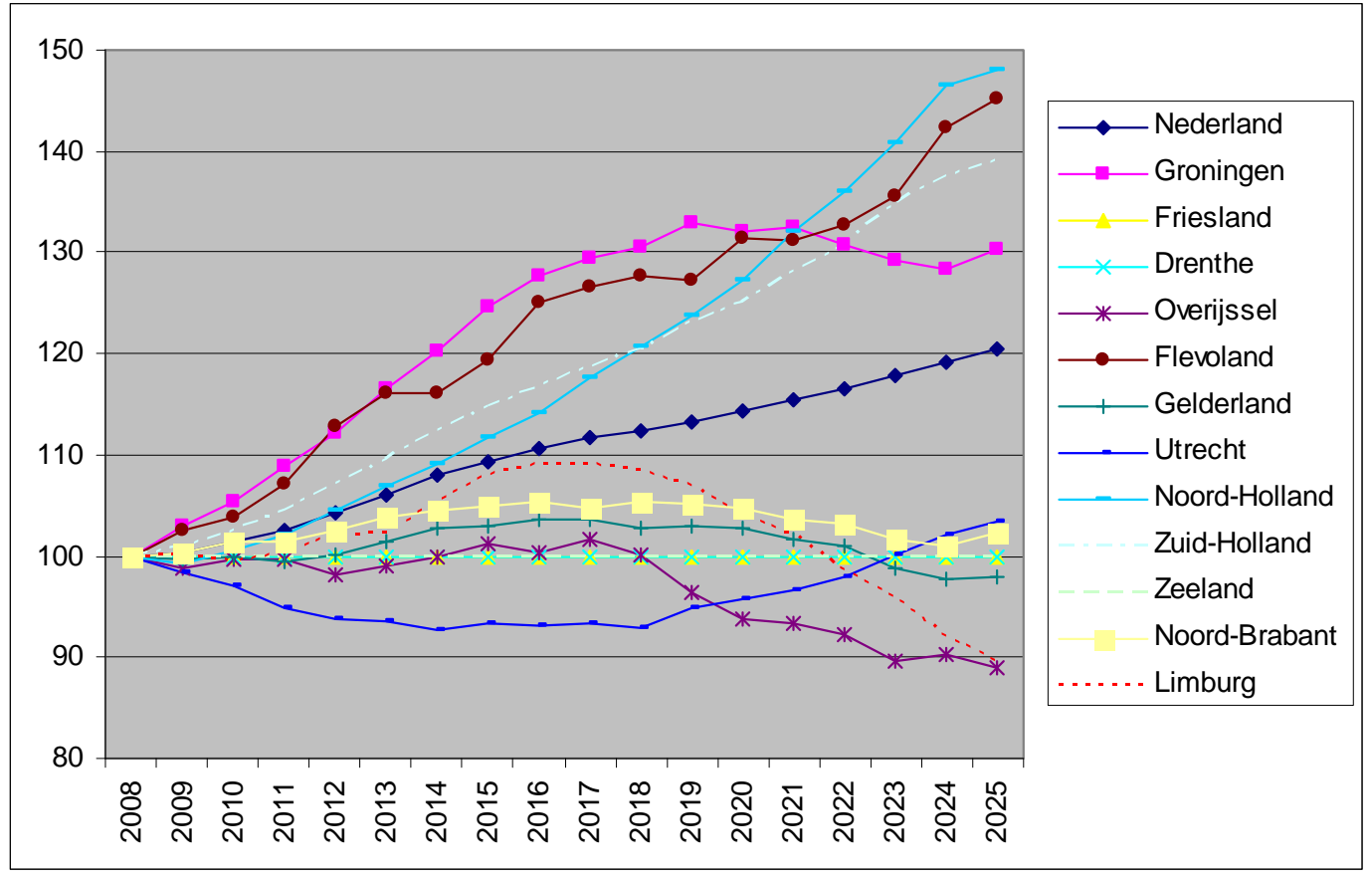

De groep westerse allochtonen met een wo-diploma techniek groeit de komende jaren gestaag in Nederland. In 2025 is deze groep volgens de prognoses met meer dan 20 \%-punt gestegen ten opzichte van 2008. Hoewel het in figuur 3.34 lijkt of Flevoland en Groningen hierin een voorname rol spelen, wordt deze groei in de praktijk met name veroorzaakt door Noord-Holland en Zuid-Holland. 
Figuur 3.35

Absoluut aantal afgestudeerde niet-westerse allochtonen wo techniek, 2008-2025

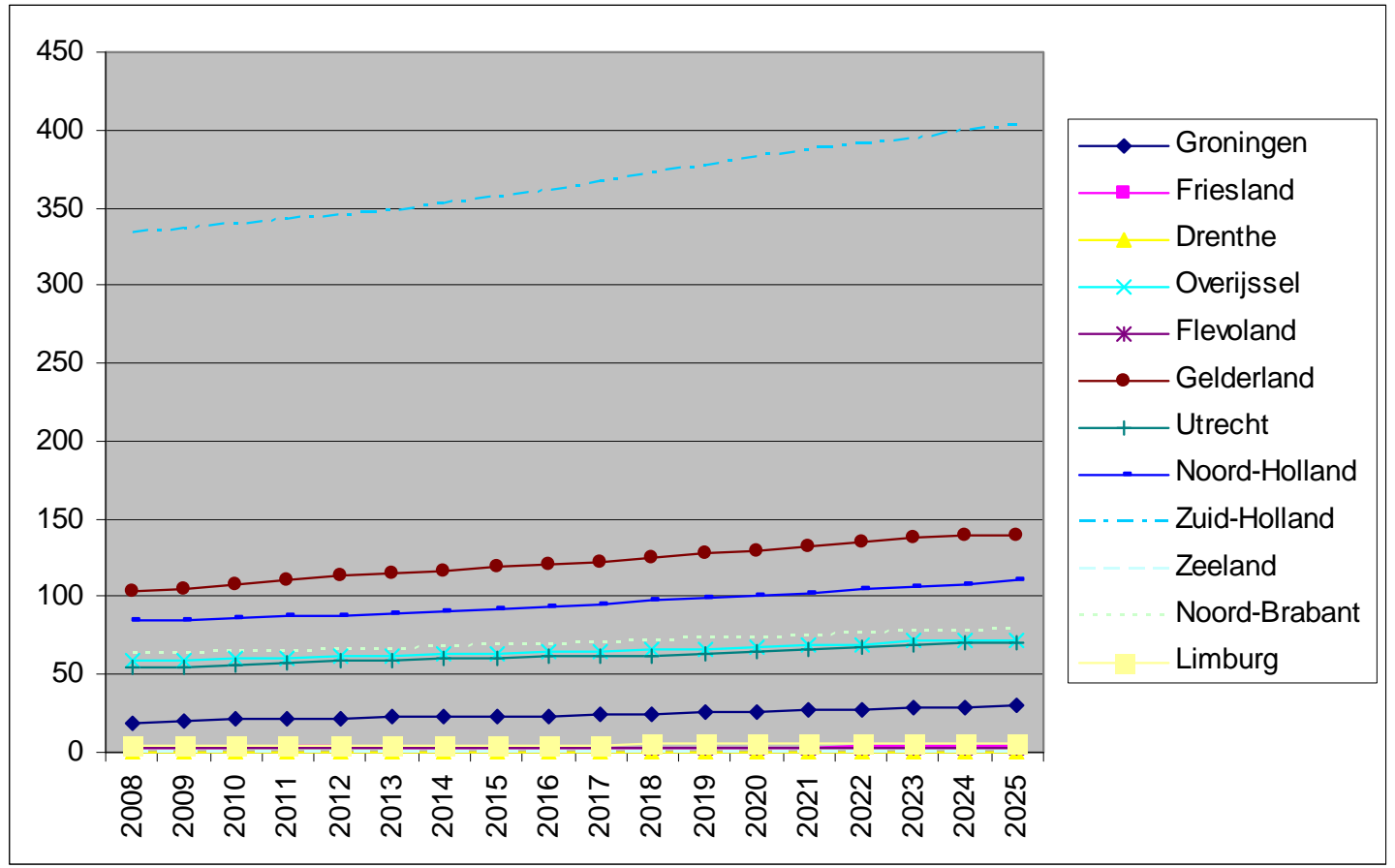

Net als de conclusies met betrekking tot westerse allochtone gediplomeerden wo techniek, kan ook voor nietwesterse allochtonen geconcludeerd worden dat deze groep absoluut gezien weinig gediplomeerden wo techniek voortbrengt. Zuid-Holland is hierop de enige uitzondering. Zuid-Holland is zowel de provincie die de meeste gediplomeerden wo techniek van niet-westerse afkomst levert, als ook de provincie waarin dit aantal gedurende de komende jaren nog het sterkst in absolute zin zal toenemen. 
Figuur 3.36

Relatief aantal afgestudeerde niet-westerse allochtonen wo techniek, 2008-2025 (2008=100)

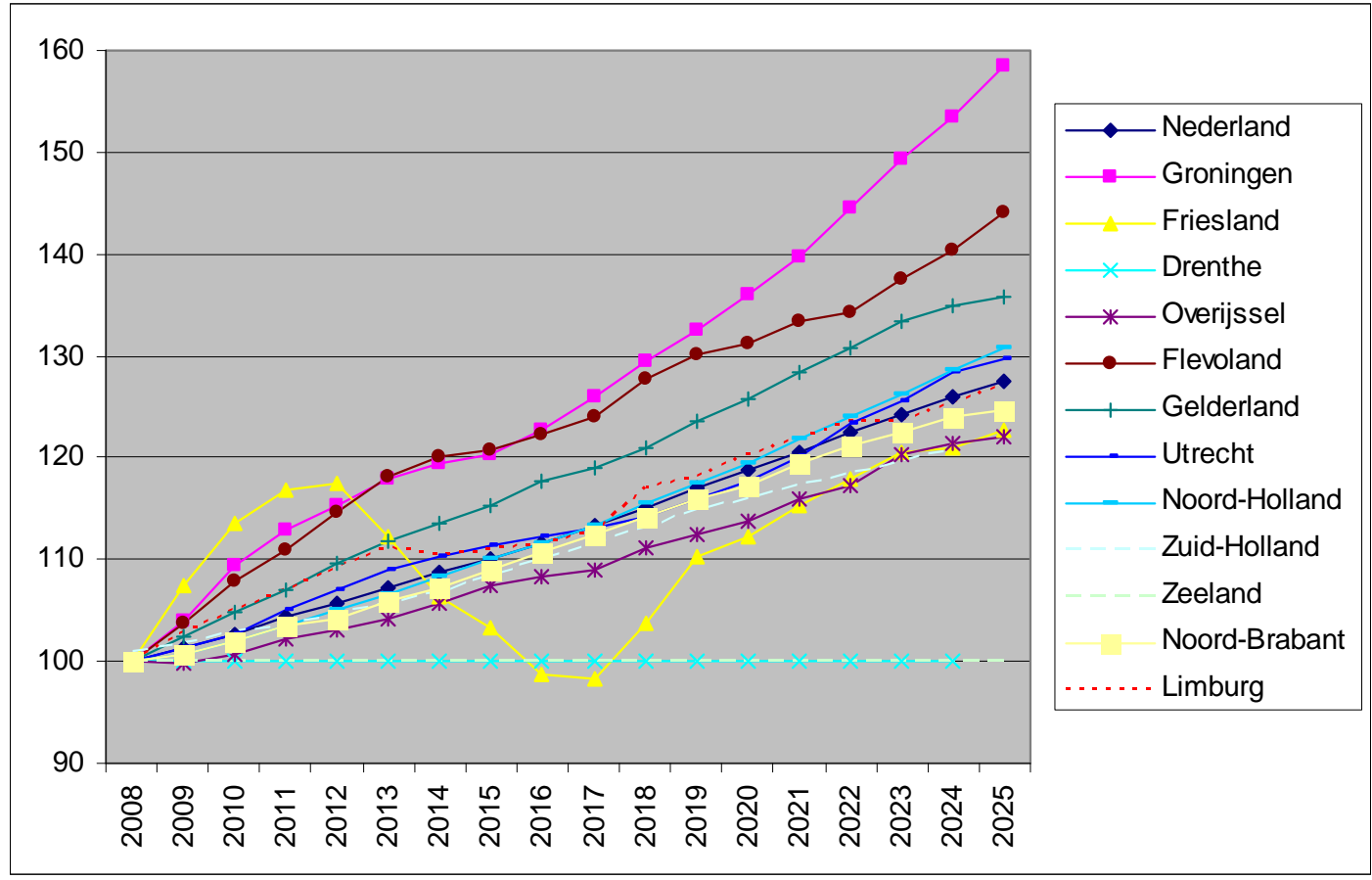

De groep niet-westerse allochtonen met een diploma wo techniek zal de komende jaren toenemen in Nederland. Zoals blijkt uit figuur 3.36 is deze groep in 2025 gegroeid met 27,6 \%-punt ten opzichte van het basisjaar. In Groningen, Flevoland en Gelderland stijgt deze groep in verhouding het snelst, maar doordat de groep nietwesterse allochtonen in deze provincies absoluut gezien klein is leidt dit ook voor deze groep niet tot opzienbarende veranderingen. 



\section{Literatuur}

Cörvers, F., J. Coenen, H. Heijke en R. Montizaan (2005), Het technisch beroepsonderwijs in het Technogebied Zuidoost-Nederland, Researchcentrum voor Onderwijs en Arbeidsmarkt, ROA-R-2005/7, Maastricht University.

Cörvers, F. (2007), Technisch onderwijs mist de slag, Economisch Statistische Berichten, Vol. 92, pp. 440-441.

OCW (2008), Referentieraming 2008, Ministerie van Onderwijs, Cultuur en Wetenschap, afdeling Kennis/PSB, Den Haag.

ROA (2007), De Arbeidsmarkt naar Opleiding en Beroep tot 2012, Researchcentrum voor Onderwijs en Arbeidsmarkt, ROA-R-2007/4, Maastricht University. 



\section{Bijlage I. Data en methodiek}

Het ROA heeft de afgelopen jaren veel ervaring opgedaan met de bestanden van de tellingen van gediplomeerden van CFI en CBS. Deze bestanden bevatten tevens een code van de regio van de onderwijsinstelling van de gediplomeerden. Deze code gaf uitsluitend de hoofdvestiging van de onderwijsinstelling aan. Daardoor diende er voorzichtig te worden omgesprongen met het vaststellen van het aantal gediplomeerden voor kleine regio's ('klein' in geografische zin).

Het CBS heeft echter onlangs besloten om geen gedetailleerde gegevens meer te verstrekken van gediplomeerden naar afstudeerregio. De reden hiervoor is dat het CBS wil voorkomen dat deze gegevens herleid kunnen worden naar de individuele onderwijsinstellingen. Daarvoor in de plaats verstrekt het CBS sinds enige tijd gegevens van gediplomeerden naar woonplaats c.q. woonregio. Doordat het CBS bevolkingsgegevens gekoppeld heeft aan de oktobertellingen is er nu niet alleen informatie beschikbaar over de woonplaats, maar ook over de leeftijd en de herkomst van de gediplomeerden. In de voorliggende scenarioanalyse wordt intensief gebruik gemaakt van deze zogenaamde 'verrijkte’ oktobertellingen.

Gedurende de onderzoeksperiode van deze studie waren de 'verrijkte' oktobertellingen slechts voor één schooljaar bekend (2005/2006). In deze studie wordt in eerste instantie het regionale aanbod van gediplomeerden naar woonprovincie vastgesteld. Het gaat hierbij voor elk opleidingsniveau (mbo, hbo en wo) om het totaal van gediplomeerden in de (bèta)technische richting, en om het totaal van gediplomeerden in de overige richtingen. Per provincie zijn zowel de gegevens van de gediplomeerden als de bevolking gedifferentieerd naar geslacht, herkomst (autochtonen, westerse allochtonen en niet-westerse allochtonen) en leeftijd (vijfjaarsklassen). De regionale bevolkingsprognoses hebben betrekking op de periode tot 2025. Om deze reden hebben ook de prognoses van het aantal gediplomeerden per provincie betrekking op de periode tot 2025.

\section{I.1 Beschikbaarheid van de data}

\section{Gediplomeerden}

Het vaststellen van de methodiek voor de scenarioanalyse was sterk afhankelijk van de beschikbare data van gediplomeerden van het onderwijs zoals door het CBS verzameld en beschikbaar gesteld. Gedurende de onderzoeksperiode bleek dat het CBS zowel de regels voor het beschikbaar stellen van databestanden als de publicatie van gegevens aan het veranderen was.

Ten aanzien van de zogenaamde Oktobertellingen is het volgende veranderd:

- De bestanden worden niet meer aangeleverd met de regio van afstuderen vanwege de herleidbaarheid naar individuele onderwijsinstellingen;

- De microbestanden dienen nu te worden afgenomen van het Centrum voor Beleidsstatistiek (CvB) van het CBS. Het CvB stelt slechts door het CBS volledig gedocumenteerde bestanden ter beschikking.

- De microbestanden die op dit moment beschikbaar zijn en relatie hebben met de probleemstelling van dit onderzoek, hebben betrekking op leerlingen in het middelbaar beroepsonderwijs (2005-2006; géén geslaagden), en studenten en geslaagden van het hoger onderwijs (1986-2006). Deze microbestanden bevatten informatie uit de Oktobertellingen en de GBA (i.e. Gemeentelijke Basisadministratie).

- Voor het middelbaar beroepsonderwijs is er informatie over de woongemeente beschikbaar (niet afstudeergemeente). Voor het hoger onderwijs is er echter geen informatie over woon- of afstudeergemeente opgenomen in de bestaande microbestanden.

Voor het toevoegen van variabelen aan bestaande bestanden of het samenstellen van nieuwe bestanden dient er een projectvoorstel te worden ingediend bij het CBS. Er moet rekening worden gehouden met de schaarse personele capaciteit van het CBS bij het indienen en bespreken van het projectvoorstel, en het uitvoeren van de 
noodzakelijke werkzaamheden voor het beschikbaar stellen van bestanden door het CBS.

Ten aanzien van de beschikbaarheid op Statline (statline.cbs.nl) is het volgende veranderd:

- Tijdreeksen van leerlingen en gediplomeerden per regio (provincie of COROP) en gedifferentieerd naar opleidingsniveau en -richting, zijn niet langer beschikbaar. Oude reeksen zijn verwijderd en vervangen door reeksen waarbij in plaats van de afstudeerregio de woonregio wordt weergegeven. Voor het mbo is slechts één jaar beschikbaar (schooljaar 2005-2006).

- Door de koppeling met de GBA is er wel gedetailleerde informatie naar geslacht, herkomst en leeftijd beschikbaar.

Het onderzoek voor de scenarioanalyse werd vertraagd omdat op Statline geen gegevens over gediplomeerden meer beschikbaar waren voor de combinatie van regio en opleidingsrichting. Omdat het CBS terughoudend was met het beschikbaar bestellen van microbestanden met de vereiste regiovariabelen, waren we zeer beperkt in het zelf maken van selecties van de relevante variabelen voor onze analyses. Uiteindelijk is er door het ROA een data-aanvraag ingediend bij het CBS, die tegemoet komt aan de terughoudendheid van het CBS en de minimale datavereisten voor de uitvoering van de scenarioanalyse. Voor de toekomst zal moeten worden overlegd tussen het CBS en het ROA over tijdige beschikbaarstelling van de microbestanden met gegevens uit de Oktobertellingen en de GBA, inclusief de regiovariabelen.

\section{Referentieramingen}

De belangrijkste bron van ramingen van gediplomeerden voor de lange termijn wordt samengesteld in het kader van de referentieramingen van het Ministerie van OCW. De ramingen dienen ter onderbouwing van de begroting van het Ministerie van OCW. Medewerkers van het ROA waren gedurende de afgelopen jaren vertegenwoordigd in de Adviescommissie Leerlingen- en Studentenramingen (ALS) die toeziet op een adequate uitvoering van de ramingen. Voor het samenstellen van de ramingen wordt het zogenaamde LECTOR-model gebruikt. In dit model worden leeftijdsafhankelijke doorstroomcoëfficiënten binnen het onderwijs gebruikt. Voor het basisjaar wordt een onderwijsmatrix gebruikt.

Het model is zeer gedetailleerd wat betreft soort onderwijs (niveau en richting), jaar van opleiding, leeftijd en geslacht. Het model is in staat om gegevens op te leveren over onder meer aantallen leerlingen en gediplomeerden, onderwijsdeelname naar leeftijd, instroom naar onderwijsherkomst, uitstroom naar onderwijsbestemming, doorstroom en schoolverlaters. Het model bevat echter geen differentiatie naar regio en herkomst (wat betreft geboorteland). Het LECTOR-model is in beginsel zeer geschikt voor uitbreiding naar deze variabelen. Het is echter onzeker of dit model (in deze vorm) blijft voortbestaan aangezien de referentieramingen niet langer door het Ministerie van OCW zelf zullen worden gemaakt, maar openbaar worden aanbesteed. Voor de voorliggende scenariostudie is de Referentieraming 2008 (OCW, 2008) gebruikt voor de controle op de nationale gegevens en voor het maken van veronderstellingen in de scenario's. Hoewel er enkele verschillen in aantallen geslaagden voorkomen in de gegevens van het CBS op Statline enerzijds en de gegevens van de Referentieramingen van OCW anderzijds, is dit voor de voorliggende studie van ondergeschikt belang.

\section{Regionale bevolkingsprognoses}

De regionale bevolkingsprognoses van het CBS staan bekend als de Regionale Kerncijfers 2005-2025 en worden eens per twee jaar door het CBS samengesteld. Volgens de agenda van het CBS zullen de gezamenlijke regionale bevolkingsprognoses van het CBS en Ruimtelijke Planbureau (RPB) op 8 september 2008 worden geactualiseerd. De bevolkingsprognoses betreffen de omvang en samenstelling van de Nederlandse bevolking op 1 januari van het prognosejaar. 


\section{I.2 Indelingen en definities}

\section{Gediplomeerden}

De gegevens van gediplomeerden zijn afkomstig van het CBS. Als basisjaar voor het maken van de prognoses is uitgegaan van de geslaagden in het studiejaar 2005-2006. Het betreft de verplichte 1 oktobertellingen van het aantal geslaagden van het voorbije studiejaar bij de door het Ministerie van Onderwijs, Cultuur en Wetenschap (OCW) en het Ministerie van Landbouw, Natuur en Voedselkwaliteit (LNV) bekostigde instellingen. Een deel van de gediplomeerden zal doorstromen binnen het onderwijs, een ander deel zal zich op de arbeidsmarkt aanbieden.

In dit rapport wordt voor zowel het middelbaar beroepsonderwijs als het hoger onderwijs geen onderscheid gemaakt naar deeltijd- en voltijdonderwijs. Voor het mbo gaat het om het totaal van gediplomeerden van BOL en BBL, ongeacht het WEB-niveau en de leerweg.

\section{Gediplomeerden mbo}

Gediplomeerden van het middelbaar beroepsonderwijs (mbo) kunnen een diploma hebben gehaald in de beroepsopleidende leerweg (BOL) of de beroepsbegeleidende leerweg (BBL). Onder BOL en BBL wordt verstaan: het onderwijs zoals opgenomen in de Wet Educatie en Beroepsonderwijs (WEB). Het betreft hier volén deeltijdonderwijs.

Het CBS ontvangt zowel van Cfi (een agentschap van het Ministerie van OCW) als van het Ministerie van LNV een bestand met de door hen verzamelde gegevens over het middelbaar beroepsonderwijs. Cfi controleert de gegevens die zij van haar berichtgevers ontvangt op volledigheid en inconsistenties en brengt zo nodig in overleg met hen verbeteringen aan in het bronbestand. Dezelfde procedure wordt uitgevoerd door het Ministerie van LNV bij de gegevens die zij van haar berichtgevers ontvangt. Na ontvangst worden door het CBS demografische gegevens uit de Gemeentelijke Basisregistratie gekoppeld aan deze bronbestanden.. 
Een gediplomeerde van het hbo heet een bachelor. Een bachelordiploma geeft toegang tot een masteropleiding in het hbo (of via een schakelprogramma de masteropleiding in het wo). De bachelorgraad werd ingevoerd bij de introductie van het zogeheten bachelor-masterstelsel (BAMA) in het hoger onderwijs in 2002-2003. Een master in het wetenschappelijk onderwijs (wo) is sinds het studiejaar 2002-2003 de tweede fase van een universitaire studie. De wo master vervangt de voormalige wo doctoraal. De geslaagden van het wo doctoraal zijn begonnen aan een doctoraalopleiding voordat het bachelor-masterstelsel werd ingevoerd. In de voorliggende studie zijn de gediplomeerden van de master- en doctoraalopleidingen van het studiejaar 2005-2006 samengevoegd.

De 1-oktobertellingen van het aantal gediplomeerden in het hoger onderwijs zijn gebaseerd op de integrale registratie op persoonsniveau door de Informatie Beheer Groep (IB-Groep). Het CBS krijgt een verrijkt bronbestand van Cfi. Daarnaast krijgt het CBS het originele bestand van de IB-Groep met extra gegevens ten behoeve van de koppeling met de Gemeentelijke Basisadministratie (GBA). De IB-Groep controleert de gegevens van de hogescholen en universiteiten op volledigheid en inconsistenties en brengt zonodig in overleg met de instellingen verbeteringen aan in het bronbestand. Vervolgens levert de IB-Groep een opgeschoond bronbestand aan Cfi. Dit agentschap verrijkt het bronbestand met een aantal gecoördineerde afleidingen (variabelen) die afgesproken zijn in de werkgroep Eéncijfer Hoger Onderwijs. In deze werkgroep zijn OCW, Cfi, het CBS, de HBO-raad en de VSNU (Vereniging van Universiteiten) vertegenwoordigd. Na ontvangst van het verrijkte bronbestand koppelt het CBS nog een aantal (nieuwe) gegevens aan het bestand. Het gaat daarbij vooral om een indeling van de studierichtingen volgens de International Standard Classification of Education (Isced) en demografische kenmerken uit de GBA.

\section{School-/studiejaar}

Bij het voortgezet onderwijs en het middelbaar beroepsonderwijs loopt een schooljaar van 1 augustus tot en met 31 juli van het volgende kalenderjaar. Bij het hoger onderwijs loopt een studiejaar van 1 september tot en met 31 augustus van het volgende kalenderjaar. De gegevens over geslaagden in het mbo hebben betrekking op een kalenderjaar en niet op een schooljaar. Zo zijn de mbo-geslaagden in 2005-2006 geslaagd in het kalenderjaar 2006.

\section{Bètatechniek}

In het middelbaar beroepsonderwijs is de indeling naar onderwijssector van het CBS als uitgangspunt genomen voor de afbakening van bètatechniek. Het gaat daarbij om de sectoren 'techniek' en 'techniek en economie'. Deze laatste sector is overigens erg klein. Voor wat betreft het hoger onderwijs gaat het om de indeling naar ISCED. Hieronder valt het totaal van 'natuurwetenschappen, wiskunde en informatica' en 'techniek, industrie en bouwkunde'.

\section{Leeftijd}

Binnen genoemd school- /studiejaar gaat het om de leeftijd op 1 januari, zoals vastgelegd in de Gemeentelijke Basisadministratie (GBA) Persoonsgegevens. De leeftijdsklassen beslaan telkens een periode van vijf jaar. Bijvoorbeeld 15-20 jaar heeft betrekking op gediplomeerden van 15 tot 20 jaar (i.e. 15 tot en met 19 jaar oud).

\section{Herkomstland}

Er wordt onderscheid gemaakt tussen autochtonen, westerse allochtonen en niet-westerse allochtonen. Autochtonen zijn personen van wie beide ouders in Nederland zijn geboren. Het gaat in deze scenarioanalyse om het totaal van de eerste generatie en tweede generatie allochtonen. Een eerste generatie allochtoon heeft als 
herkomstgroepering het land waar hij of zij is geboren. Een tweede generatie allochtoon heeft als herkomstgroepering het geboorteland van de moeder, tenzij dat ook Nederland is. In dat geval is de herkomstgroepering bepaald door het geboorteland van de vader. Westerse allochtonen hebben als land van herkomst één van de landen in de werelddelen Europa (exclusief Turkije), Noord-Amerika, en Oceanië of Indonesië of Japan. Op grond van hun sociaaleconomische en sociaal-culturele positie worden allochtonen uit Indonesië en Japan tot de westerse allochtonen gerekend. Het gaat vooral om mensen die in het voormalig Nederlands-Indië zijn geboren en werknemers van Japanse bedrijven met hun gezin. Niet-westerse allochtonen hebben als herkomstland één van de landen in Afrika, Latijns-Amerika en Azië (exclusief Indonesië en Japan) of Turkije.

In dit rapport is de (relatief kleine) groep personen van wie de herkomst onbekend is gerekend tot de nietwesterse allochtonen.

\section{Regio}

De regio van de gediplomeerde is bepaald aan de hand van de woongemeente. In de scenarioanalyse is onderscheid gemaakt naar woonprovincie. Voor een klein deel van gediplomeerden is deze niet bekend (mogelijk omdat zij in het buitenland woonachtig zijn). Voor de hoger opgeleiden dient er rekening mee gehouden te worden dat zij hun woonadres tijdens hun studieperiode niet doorgeven aan de gemeente, waardoor de provincie waarin ze op kamers wonen en afstuderen kan verschillen van de provincie waarin ze volgens de GBA woonachtig zijn.

\section{I.3 Prognosemethodiek}

Voor het uitvoeren van de scenarioanalyse is er een model ontwikkeld dat het aantal gediplomeerden in de technische richting per regio verklaart uit de demografische ontwikkelingen alsmede de ontwikkelingen in de opleidingskeuze naar geslacht en herkomst. De verklarende factoren voor de toekomstige ontwikkeling van het aantal (bèta)technisch gediplomeerden per provincie zijn dus:

- de regionale bevolkingsontwikkeling tot 2025 naar geslacht, herkomst en leeftijd;

- $\quad$ het aandeel van de bevolking dat een mbo-, hbo- of wo-diploma behaalt gedifferentieerd naar geslacht, herkomst en leeftijd;

- $\quad$ het aandeel van de gediplomeerden dat een diploma in de bètatechnische richting behaalt, wederom gedifferentieerd naar geslacht, herkomst en leeftijd.

De belangrijkste variabelen in de scenarioanalyse zijn de regionale bevolkingsontwikkeling tot 2025, en de deelname van vrouwen en allochtonen in de (bèta)technische richting. Bij een toename van de regionale bevolking neemt het potentiële arbeidsaanbod op alle opleidingsniveaus en in alle -richtingen toe. Bij een grotere participatie van vrouwen en allochtonen gaat een groter potentieel aanbod aan gediplomeerden met een (bèta)technische opleiding ten koste van het potentiële aanbod in de overige opleidingsrichtingen.

De methodiek die hier wordt gehanteerd is gebaseerd op de zogenaamde 'participatieratio'-methode. Er wordt in beginsel uitgegaan van vaste verhoudingen tussen het aantal gediplomeerden van een bepaalde leeftijd en de bevolking met dezelfde leeftijd. Hetzelfde geldt voor de verhouding tussen het aantal gediplomeerden in de technische richting en het totaal aantal gediplomeerden van alle richtingen. Omdat het CBS tot op heden voor uitsluitend het jaar 2006 de gewenste gegevens heeft over gediplomeerden naar geslacht, leeftijd, herkomst, opleidingsrichting en woonregio, worden de verhoudingsgetallen van 2006 als uitgangspunt voor de prognoses gebruikt. Hieronder wordt stapsgewijs aangegeven hoe de prognose van het aantal gediplomeerden per woonregio is gemaakt. De methodiek is hetzelfde voor alle provincies en verschilt niet voor mbo, hbo of wo. De gebruikte gegevens hebben telkens betrekking op provinciale verbijzonderingen, tenzij anders is aangegeven (zie stap 3b). 
Stap 1 Bevolkingsomvang 2006-2025

Bepaal op basis van gegevens van het CBS het aantal personen in de bevolking naar geslacht, herkomst en leeftijdsklassen van vijf jaar voor het jaar 2006, en voor de periode tot 2025.

Stap 2 Aantal gediplomeerden mbo, hbo of wo in 2006

Bepaal op basis van gegevens van het CBS het aantal gediplomeerden van mbo, hbo of wo naar geslacht, herkomst en leeftijdsklassen van vijf jaar voor het jaar 2006.

Stap 3a Aandeel gediplomeerden mbo, hbo of wo in 2006

Bepaal het aandeel gediplomeerden van mbo, hbo of wo naar geslacht, herkomst en leeftijdsklassen van vijf jaar voor het jaar 2006. Dit gebeurt door de uitkomsten van stap 2 te delen door die van stap 1.

Stap $3 b$ Aandeel gediplomeerden mbo, hbo of wo tot 2025

Bepaal de groei van het aandeel gediplomeerden van mbo, hbo of wo in de bevolking van 15 jaar en ouder tot 2025. Het aantal gediplomeerden van mbo, hbo en wo is afkomstig uit de Referentieramingen van OCW. Door het aantal te delen door de bevolking is bekend hoe het aandeel voor elk opleidingsniveau groeit. Dit gegeven is alleen bekend voor Nederland als geheel, en wordt voor alle provincies gelijk verondersteld.

Stap 4 Aantal gediplomeerden mbo, hbo of wo tot 2025

Vermenigvuldig de uitkomst van stap 3a en b (aandeel van opleidingsniveau in bevolking in 2006 en tot 2025) met de verwachte bevolkingontwikkeling tot 2025. Hieruit resulteert het aantal gediplomeerden van mbo, hbo, wo tot 2025 gedifferentieerd naar geslacht, herkomst en leeftijdsklassen van vijf jaar.

Stap 5 Aantal gediplomeerden bètatechniek van mbo, hbo of wo in 2006

Bepaal op basis van de gegevens van het CBS het aantal gediplomeerden bètatechniek van mbo, hbo of wo naar geslacht, herkomst en leeftijdsklassen van vijf jaar voor het jaar 2006.

Stap 6a Aandeel gediplomeerden bètatechniek mbo, hbo of wo in 2006

Bepaal het aandeel gediplomeerden bètatechniek van mbo, hbo of wo naar geslacht, herkomst en leeftijdsklassen van vijf jaar voor het jaar 2006. Dit gebeurt door de uitkomsten van stap 5 te delen door die van stap 4.

Stap $6 b$ Aandeel gediplomeerden bètatechniek mbo, hbo of wo tot 2025

Bepaal in het invoerscherm van de Excel-tool hoe groot de gemiddelde groei tot 2025 is van het aandeel gediplomeerden bètatechniek naar geslacht en herkomstgroepering. De groei wordt standaard op $0 \%$ gezet.

Stap 7 Aantal gediplomeerden bètatechniek mbo, hbo of wo tot 2025

Vermenigvuldig de uitkomst van stap 6 (i.e. aandeel techniek onder gediplomeerden van mbo, hbo of wo) met de verwachte ontwikkeling van het totale aantal mbo-, hbo- of wo-gediplomeerden tot 2025 uit stap 4. Hieruit resulteert het aantal gediplomeerden bètatechniek van mbo, hbo, wo tot 2025 gedifferentieerd naar geslacht, herkomst en leeftijdsklassen van vijf jaar.

Stap 8 Aggregatie over geslacht, herkomst en leeftijdsklassen

Aggregeer het verwachte aantal gediplomeerden van mbo, hbo en wo tot 2025 naar wens over geslacht, herkomst en leeftijdsklassen.

Het gebruikte prognosemodel heeft het voordeel dat het waarschijnlijk robuuste uitkomsten oplevert wat betreft het toekomstige aantal gediplomeerden in een regio. Toch dienen voor een goede inschatting hiervan de prognoses vergeleken te worden met de updates van deze prognoses ten gevolge van het beschikbaar komen van nieuwe regionale bevolkingsprognoses van het CBS, referentieramingen van het Ministerie van OCW, en uiteraard de oktobertellingen van CFI. 
Verder is een nadeel van de huidige methode dat de informatie over het aantal leerlingen dat in de pijplijn van het onderwijs zit, niet wordt gebruikt. De leerlingentellingen zijn op zichzelf heel geschikt als uitgangspunt voor de ramingen van het aantal gediplomeerden (zoals in ROA, 2007), maar de methodiek die dan moet worden toegepast vergt meer gegevens - vooral over de doorstroom binnen het onderwijs - en de ontwikkeling van een ingewikkelder model met een regionale dimensie.

Tot slot is het mogelijk om de informatie over het aantal gediplomeerden in de bètatechnische richting verder te verfijnen naar opleidingsrichting binnen bètatechniek en regio. Hier loopt men echter al snel tegen de ondergrenzen aan van wat het CBS wil vrijgeven. Voor met name grotere provincies is een verfijning mogelijk naar bijv. COROP-gebieden en technische opleidingen. Er zullen ook in dat geval met het CBS afspraken moeten worden gemaakt over een andere aanlevering van de data, waarbij de toegang tot de microbestanden via de remote-access verbinding van het ROA met de servers van het CBS is geregeld.

\section{I.4 Gebruik van Excel-files}

In de drie bijgeleverde Excel-files worden de bovenstaande stappen doorlopen. De drie aparte files hebben betrekking op respectievelijk het mbo, hbo en wo. De gegevens in het rood zijn afkomstig van het CBS, of hebben betrekking op de invoer van de gebruiker. Alle overige gegevens die zichtbaar zijn, hebben betrekking op doorberekeningen met de CBS-gegevens of de ingevoerde gegevens. De gegevens kunnen uitsluitend worden ingevoerd binnen het werkblad 'Invoer'.

Binnen elke file zijn er voor de provincies aparte werkbladen. Er zijn per provincie aparte tabbladen voor mannen, vrouwen en totaal. In het werkblad 'Overzicht' staan de kerngegevens van de provincies onder elkaar: het aandeel van de gediplomeerden met een bètatechnische opleiding, het aantal gediplomeerden bètatechniek, en het totaal aantal gediplomeerden van het betreffende opleidingsniveau. Bovenaan het werkblad 'Overzicht' kunnen selecties gemaakt worden van regio en geslacht.

Per werkblad van provincie en geslacht worden de gegevens van aantallen gediplomeerden naar leeftijd en herkomst gedetailleerd weergegeven. Het gaat hierbij telkens om het aantal gediplomeerden per opleidingsniveau, het aandeel bètatechniek op het betreffende opleidingsniveau, en het aantal gediplomeerden in bètatechniek per opleidingsniveau. Bovenaan het werkblad zijn deze gegevens geaggregeerd over de leeftijdscategorieën en herkomstgroeperingen. Omwille van de overzichtelijkheid zijn de regionale bevolkingsgegevens en de doorberekeningen met de regionale bevolkingsgegevens onzichtbaar gemaakt. 
Bijlage II. Prognoses technisch opgeleiden per opleidingsniveau naar geslacht en herkomst, 2008-2025 


\section{Mbo}

Figuur II.1

Absoluut aantal afgestudeerde autochtone mannen mbo techniek, 2008-2025

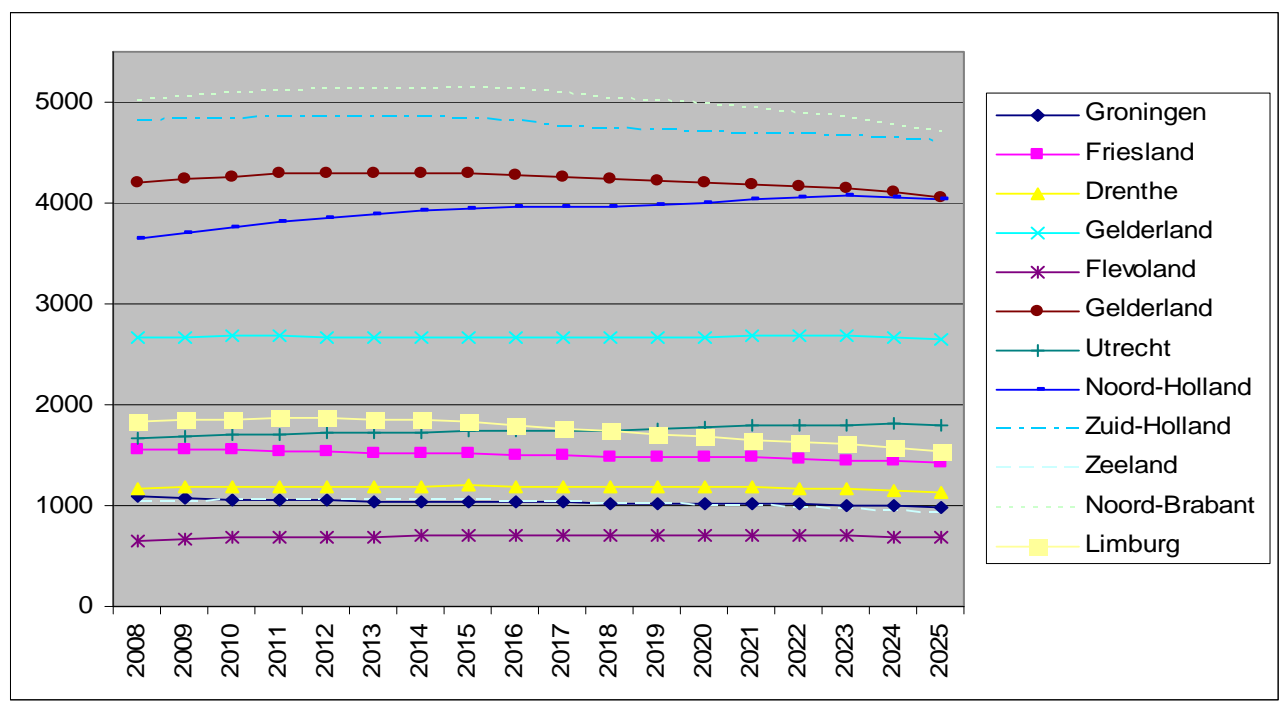

Figuur II.2

Relatief aantal afgestudeerde autochtone mannen mbo techniek, 2008-2025 (geïndexeerd op 2008=100)

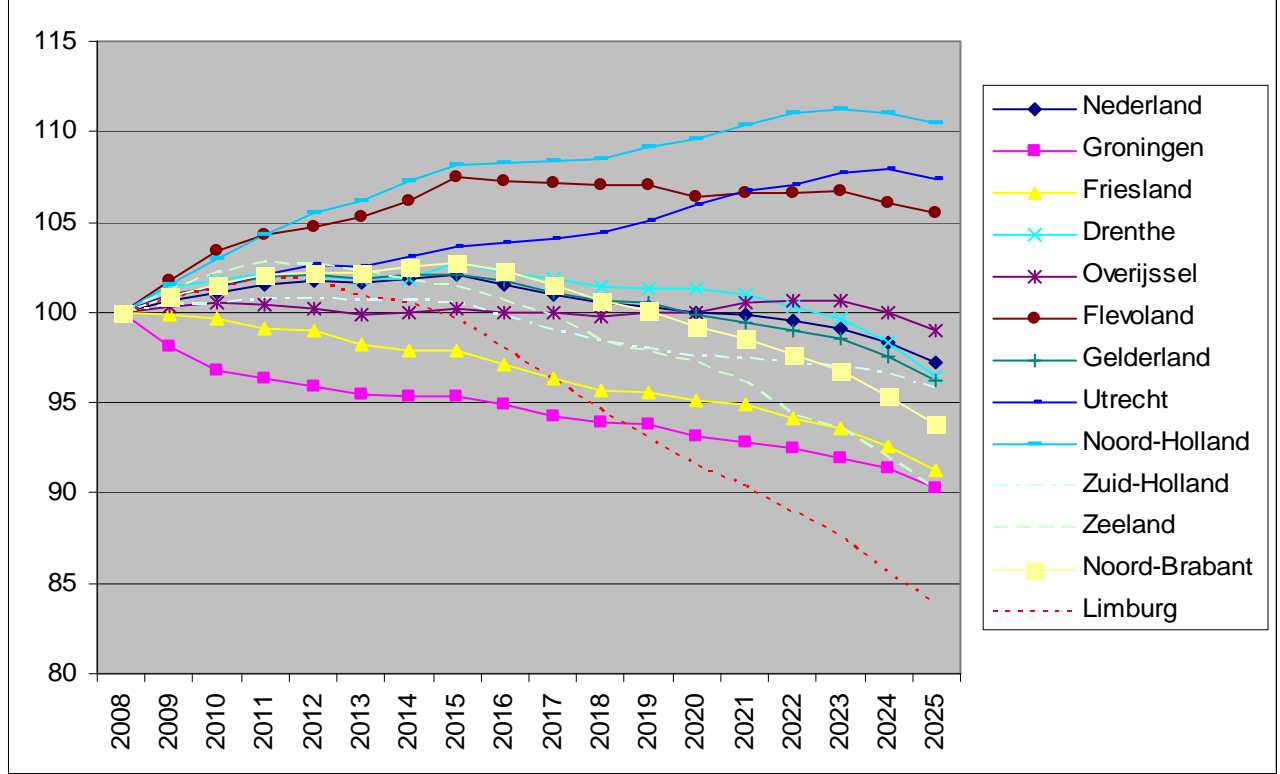




\section{Figuur II.3}

Absoluut aantal afgestudeerde westerse allochtone mannen mbo techniek, 2008-2025

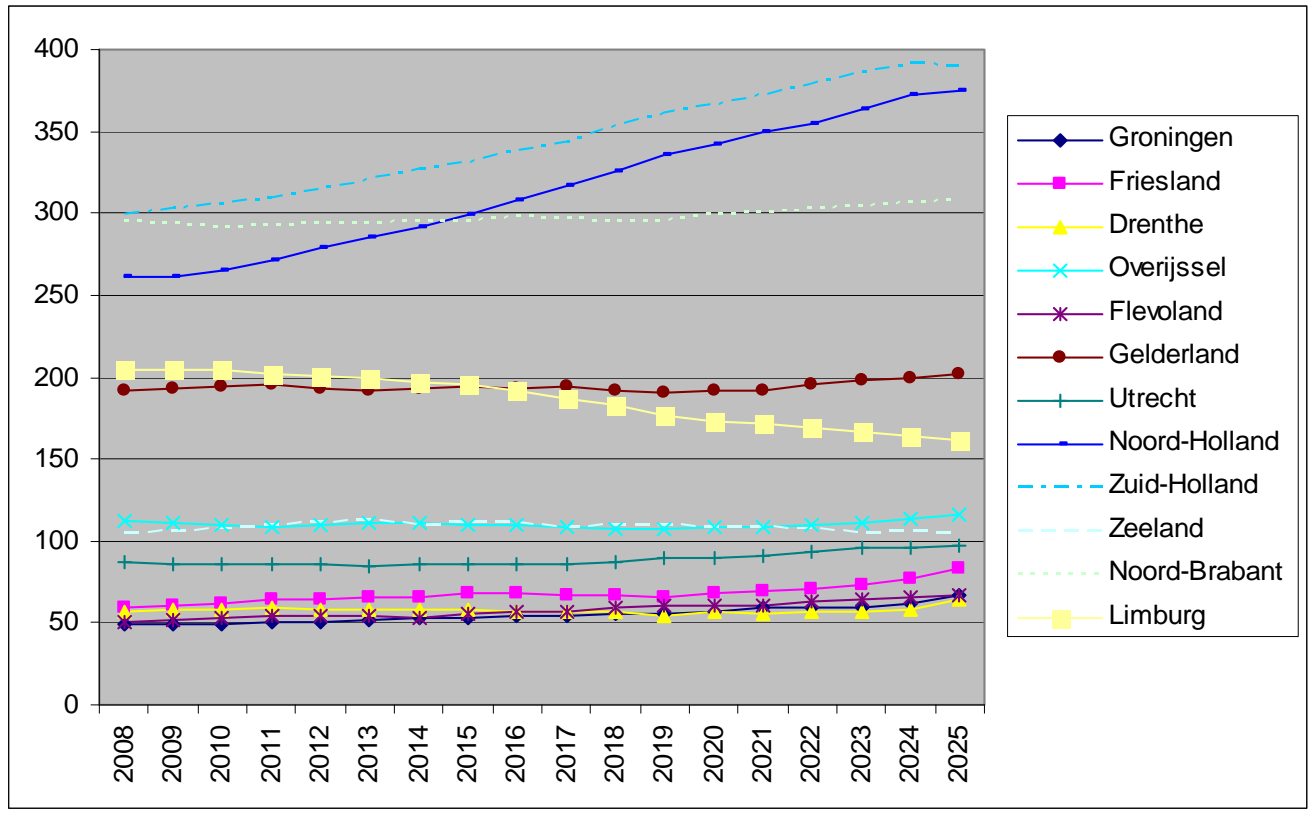

\section{Figuur II.4}

Relatief aantal afgestudeerde westerse allochtone mannen mbo techniek, 2008-2025 (geïndexeerd op 2008=100)

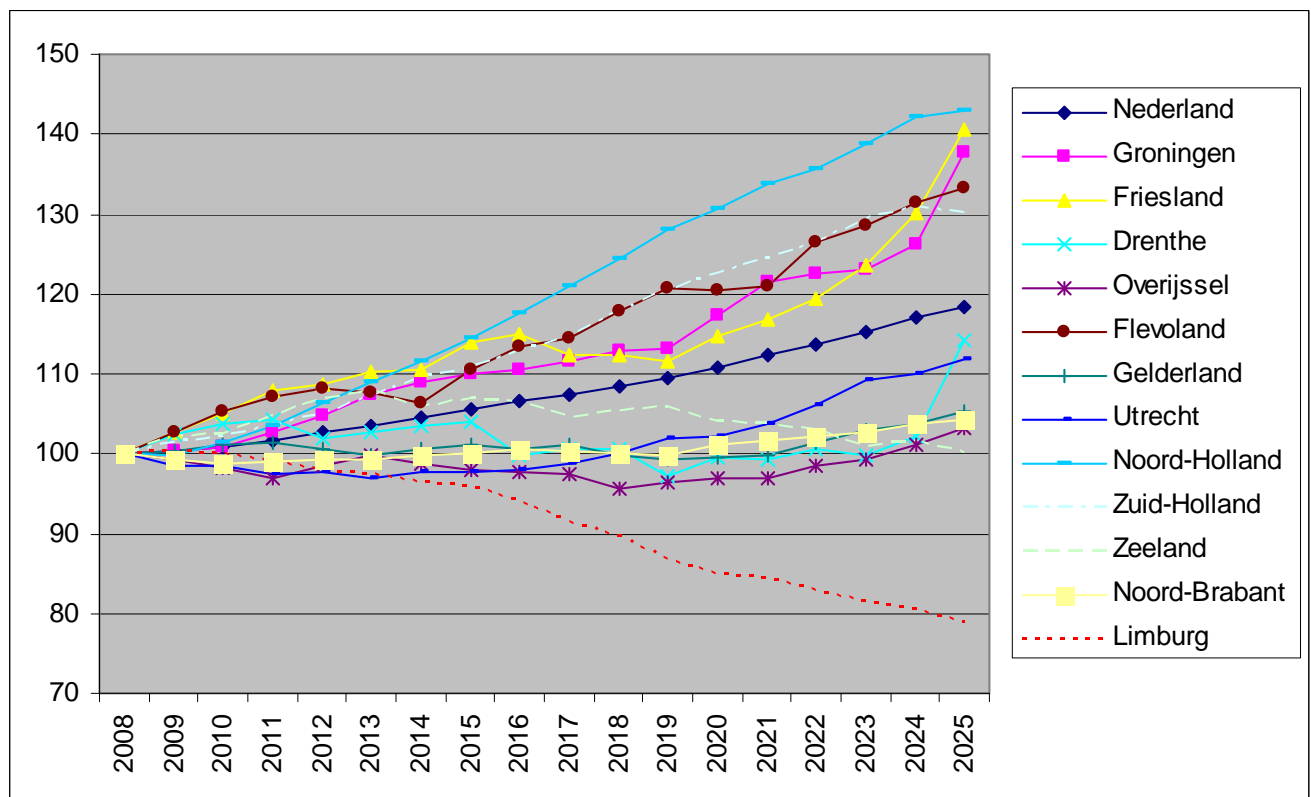




\section{Figuur II.5}

Absoluut aantal afgestudeerde niet-westerse allochtone mannen mbo techniek, 2008-2025

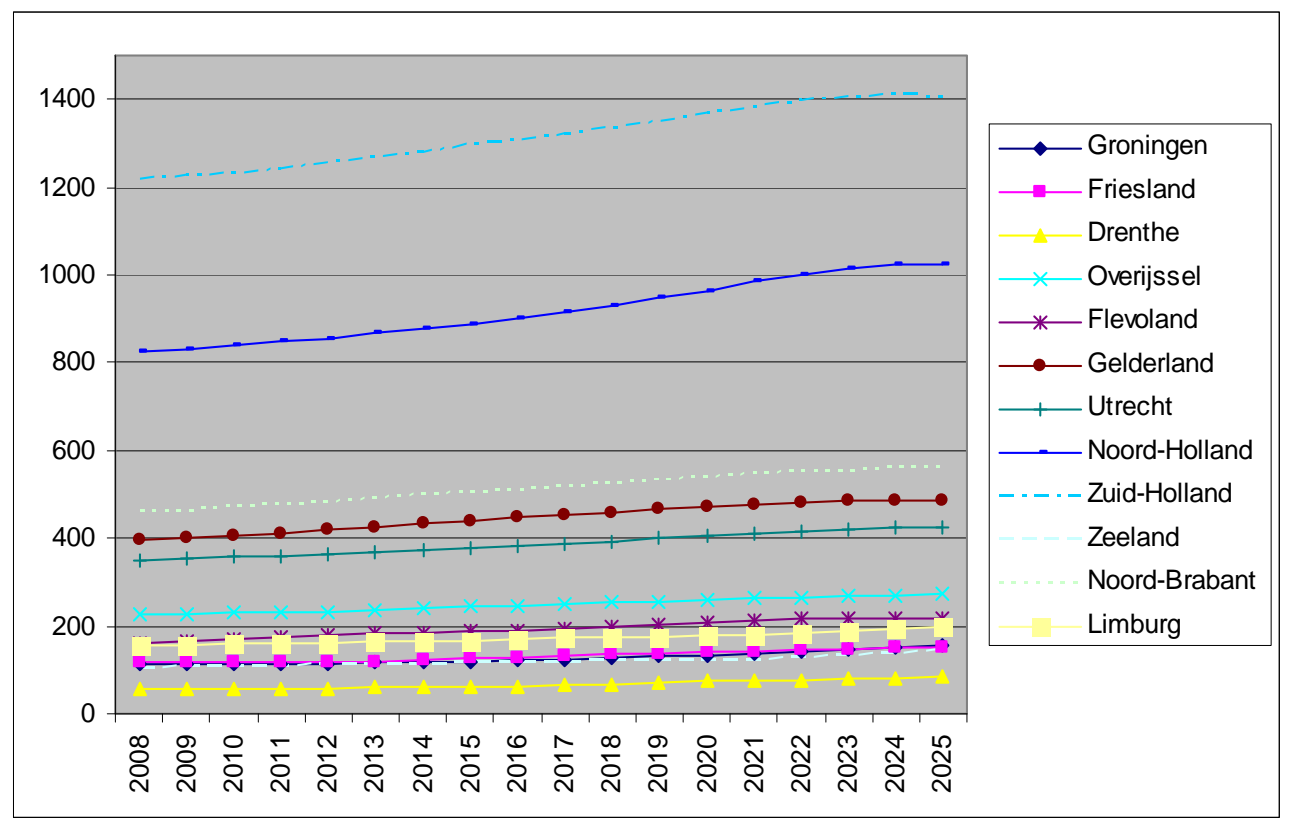

Figuur II.6

Relatief aantal afgestudeerde niet-westerse allochtone mannen mbo techniek, 2008-2025 (geïndexeerd op 2008=100)

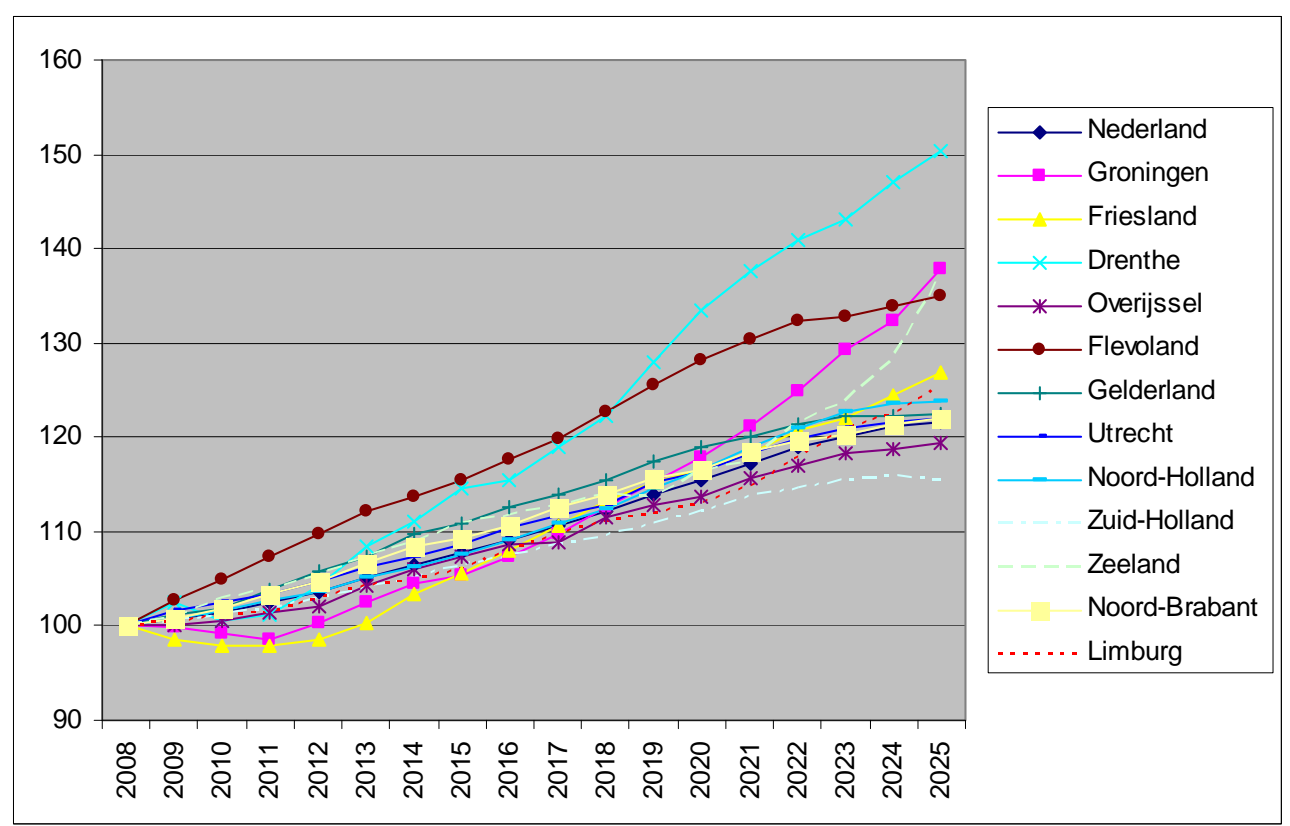


Figuur II.7

Absoluut aantal afgestudeerde autochtone vrouwen mbo techniek, 2008-2025

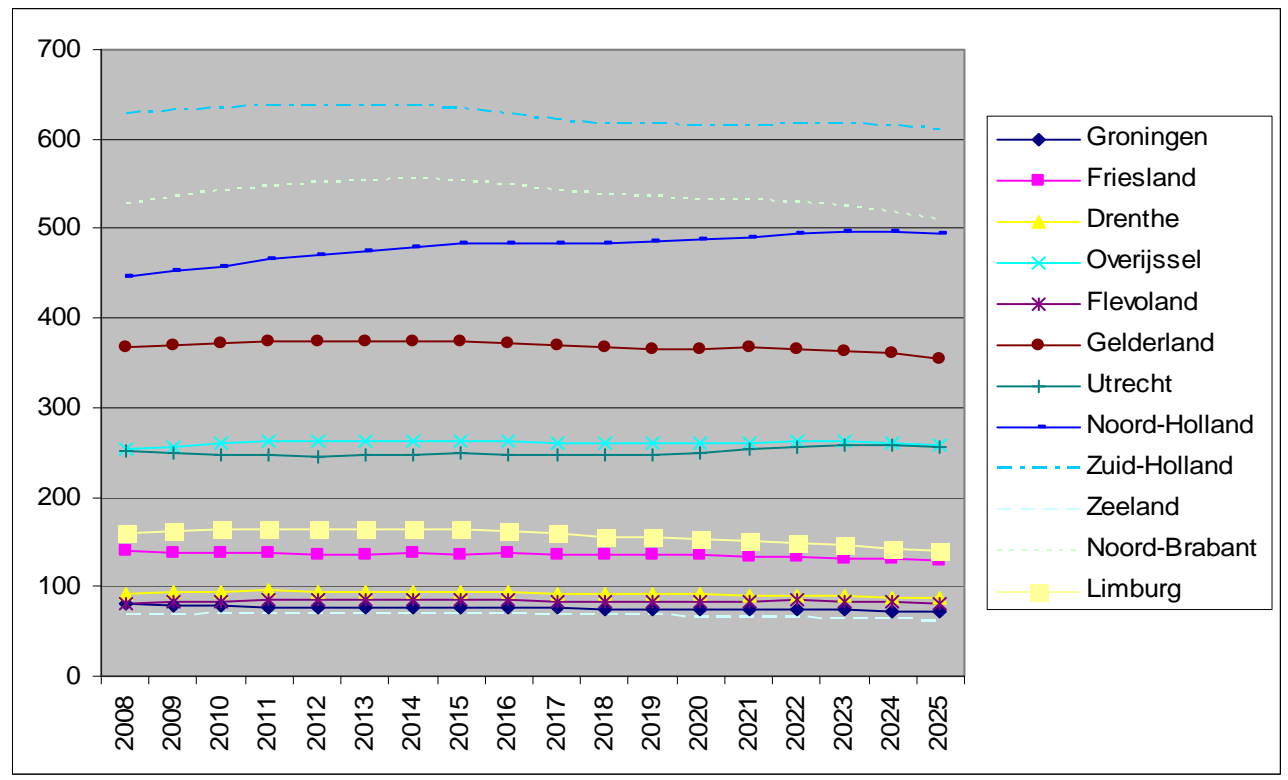

Figuur II.8

Relatief aantal afgestudeerde autochtone vrouwen mbo techniek, 2008-2025 (geïndexeerd op 2008=100)

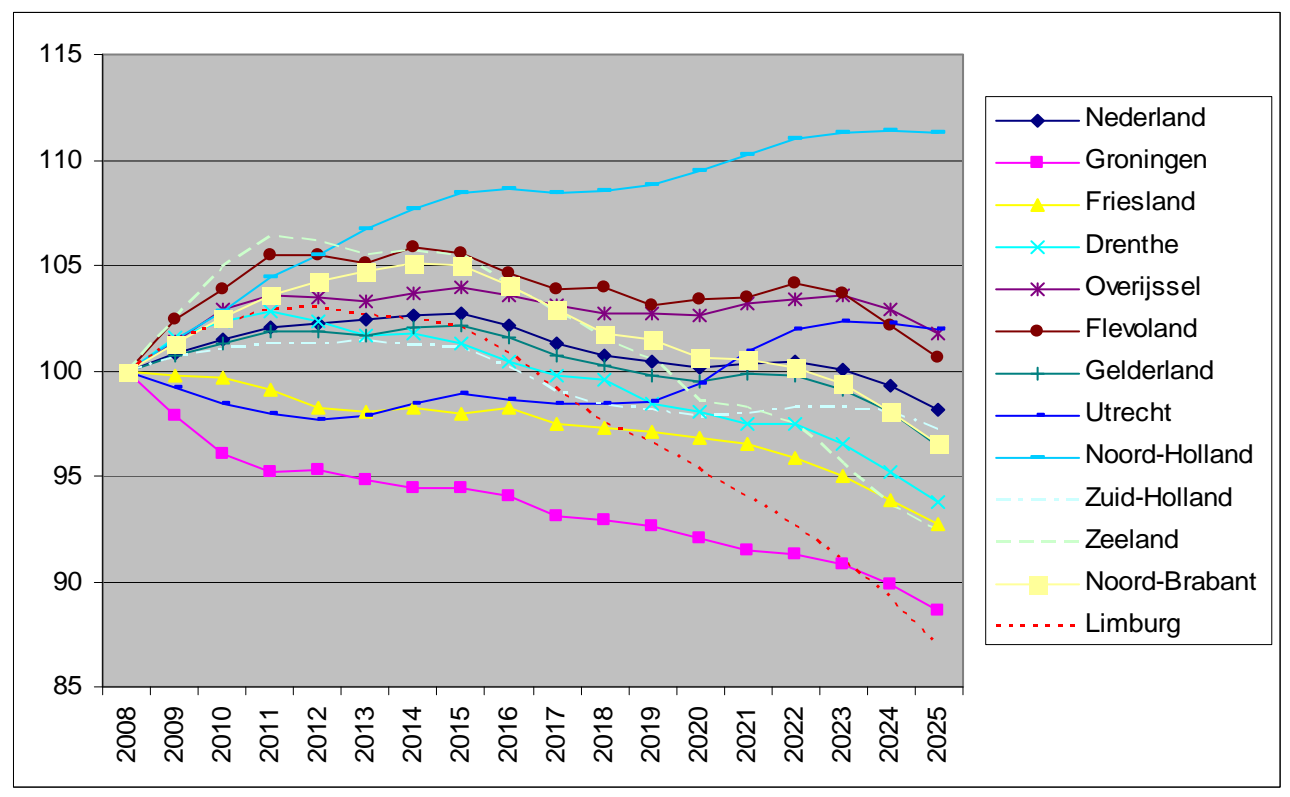


Figuur II.9

Absoluut aantal afgestudeerde westerse allochtone vrouwen mbo techniek, 2008-2025

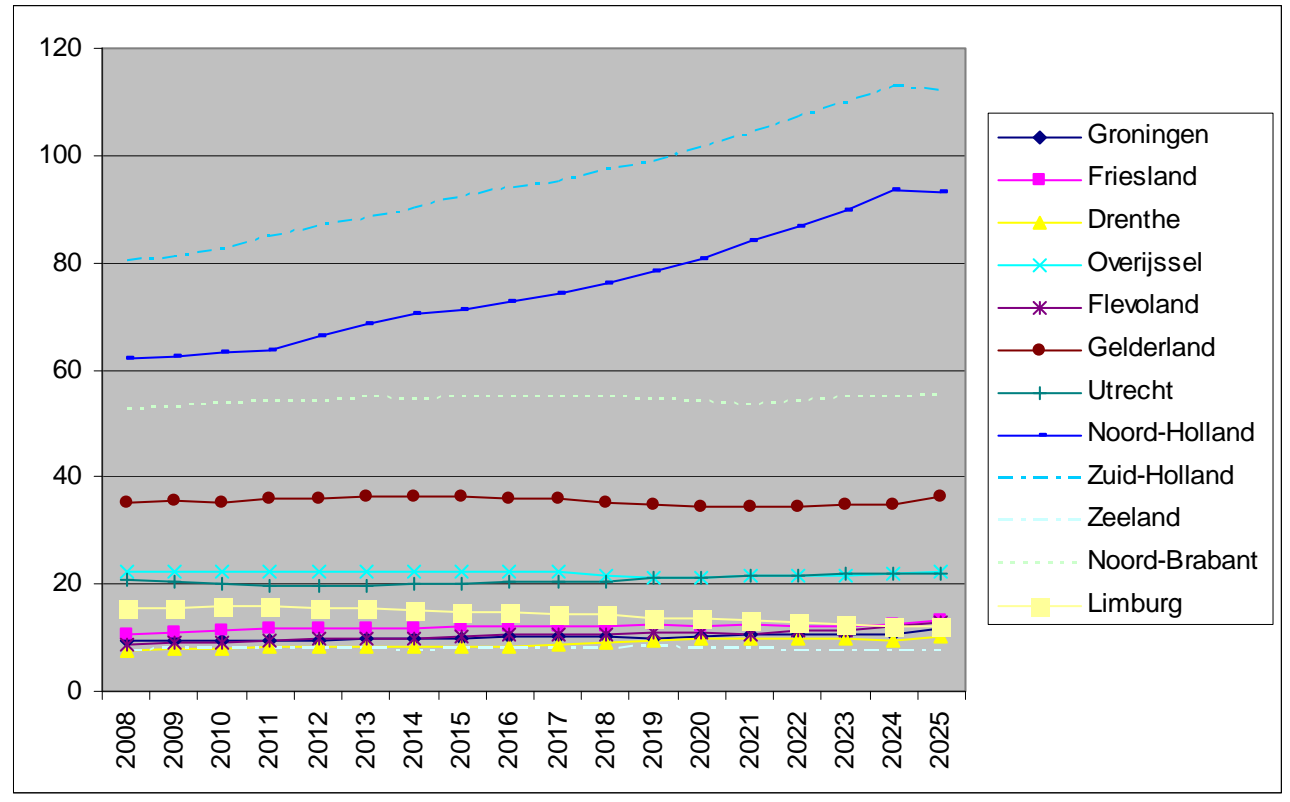

Figuur II.10

Relatief aantal afgestudeerde westerse allochtone vrouwen mbo techniek, 2008-2025 (geïndexeerd op 2008=100)

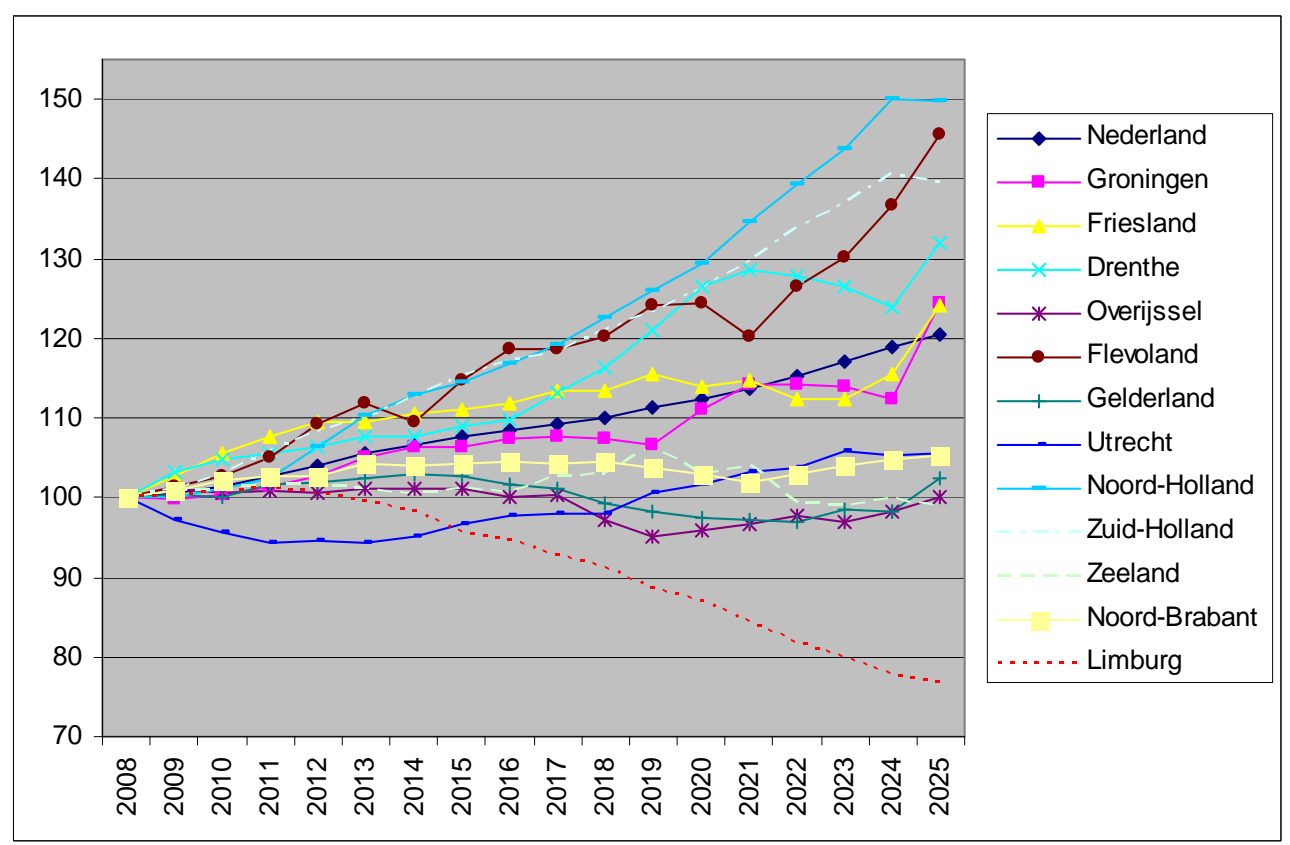




\section{Figuur II.11}

Absoluut aantal afgestudeerde niet-westerse allochtone vrouwen mbo techniek, 2008-2025

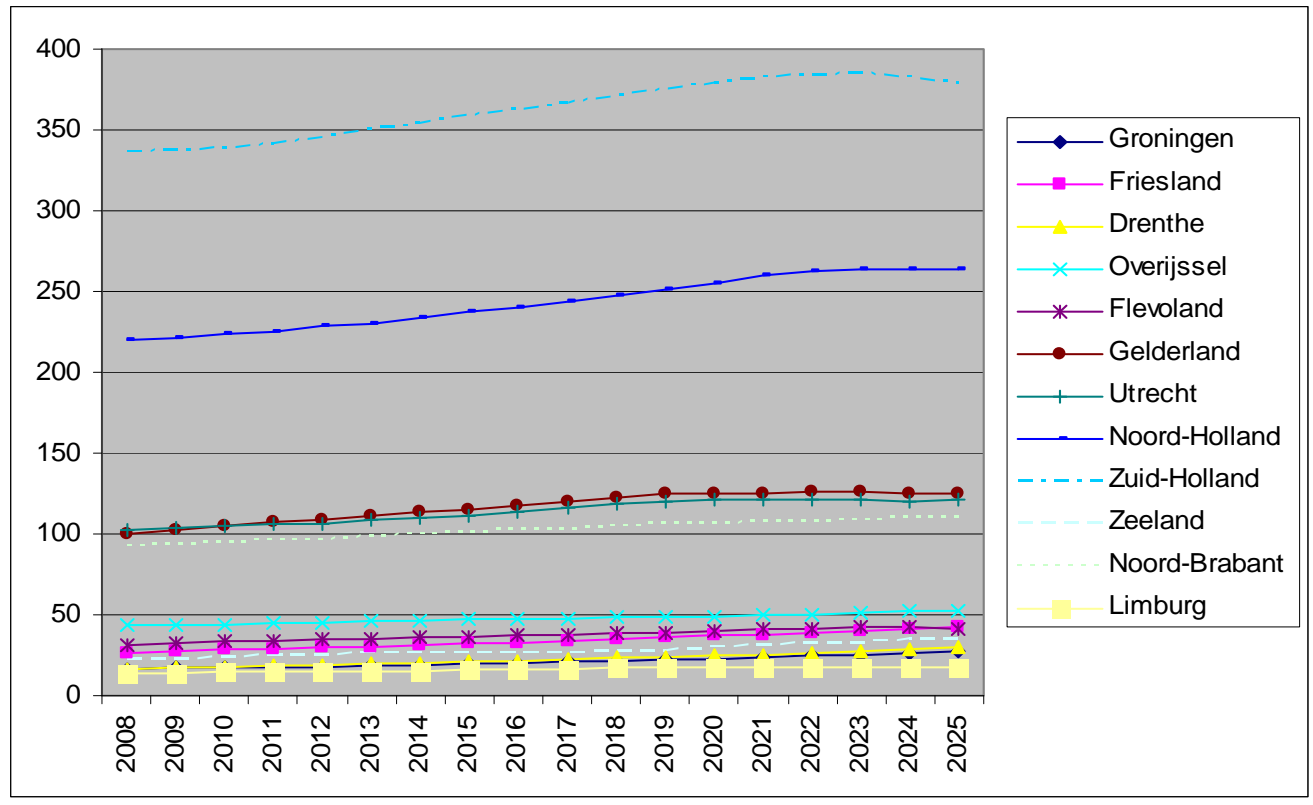

Figuur II.12

Relatief aantal afgestudeerde niet-westerse allochtone vrouwen mbo techniek, 2008-2025 (geïndexeerd op 2008=100)

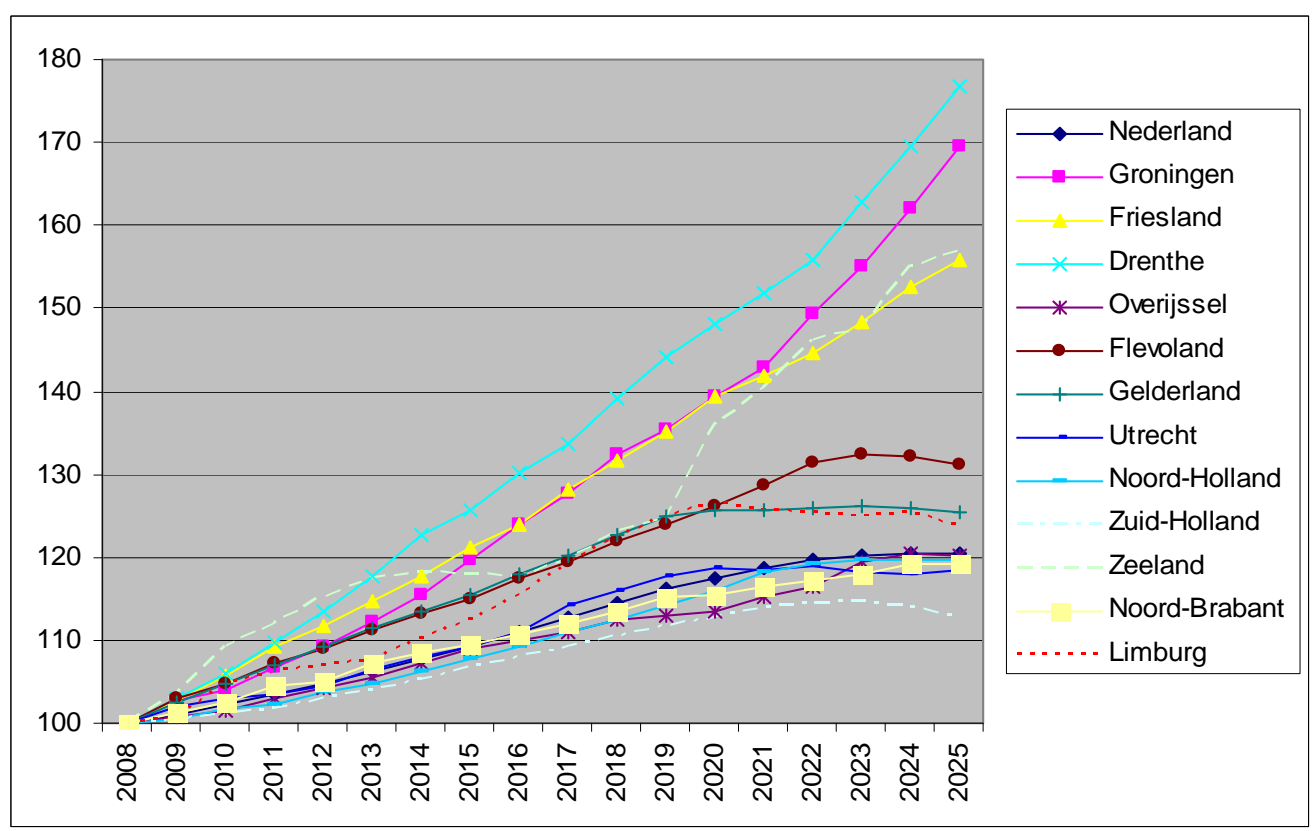




\section{Hbo}

Figuur II.13

Absoluut aantal afgestudeerde autochtone mannen hbo techniek, 2008-2025

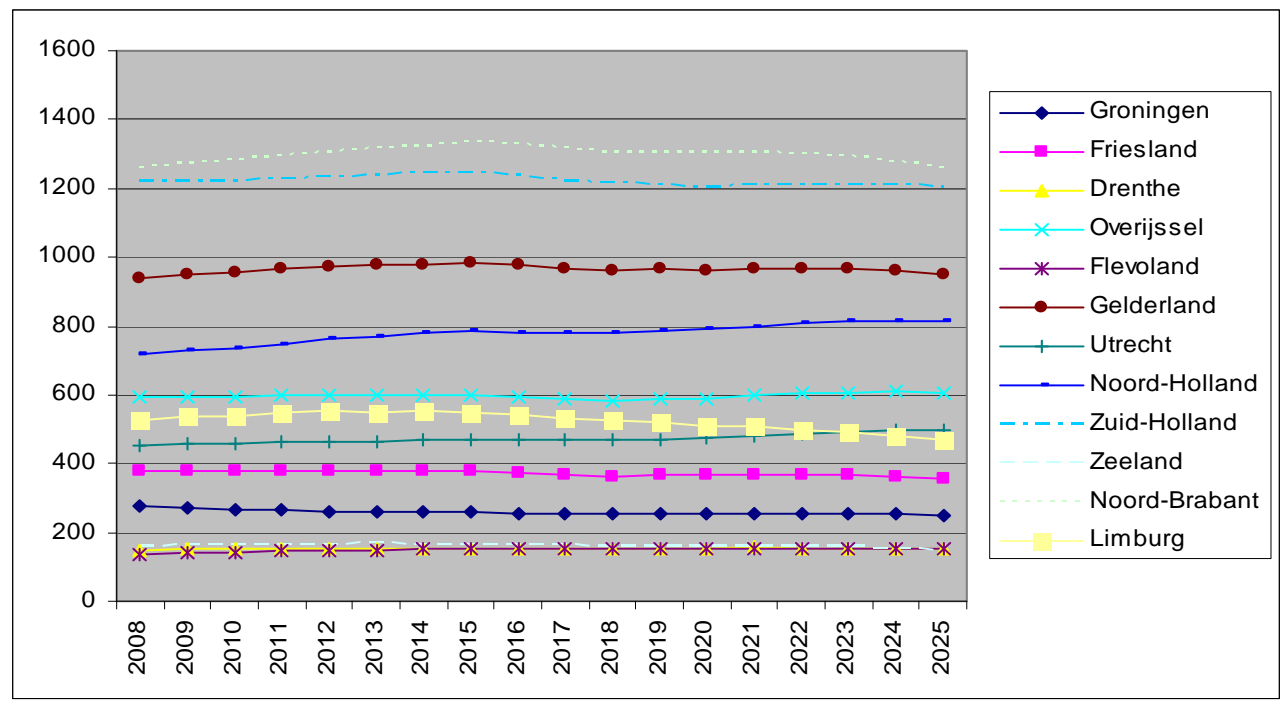

Figuur II.14

Relatief aantal afgestudeerde autochtone mannen hbo techniek, 2008-2025 (geïndexeerd op 2008=100)

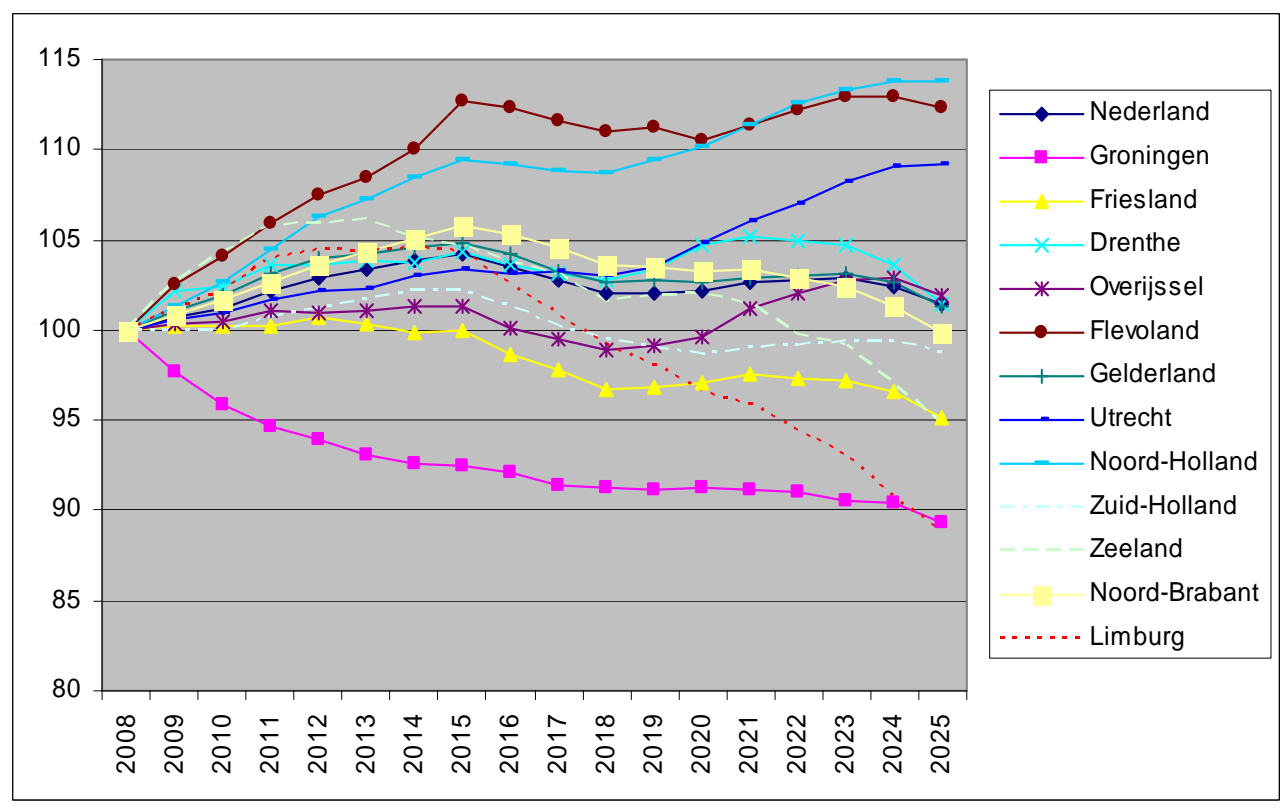




\section{Figuur II.15}

Absoluut aantal afgestudeerde westerse allochtone mannen hbo techniek, 2008-2025

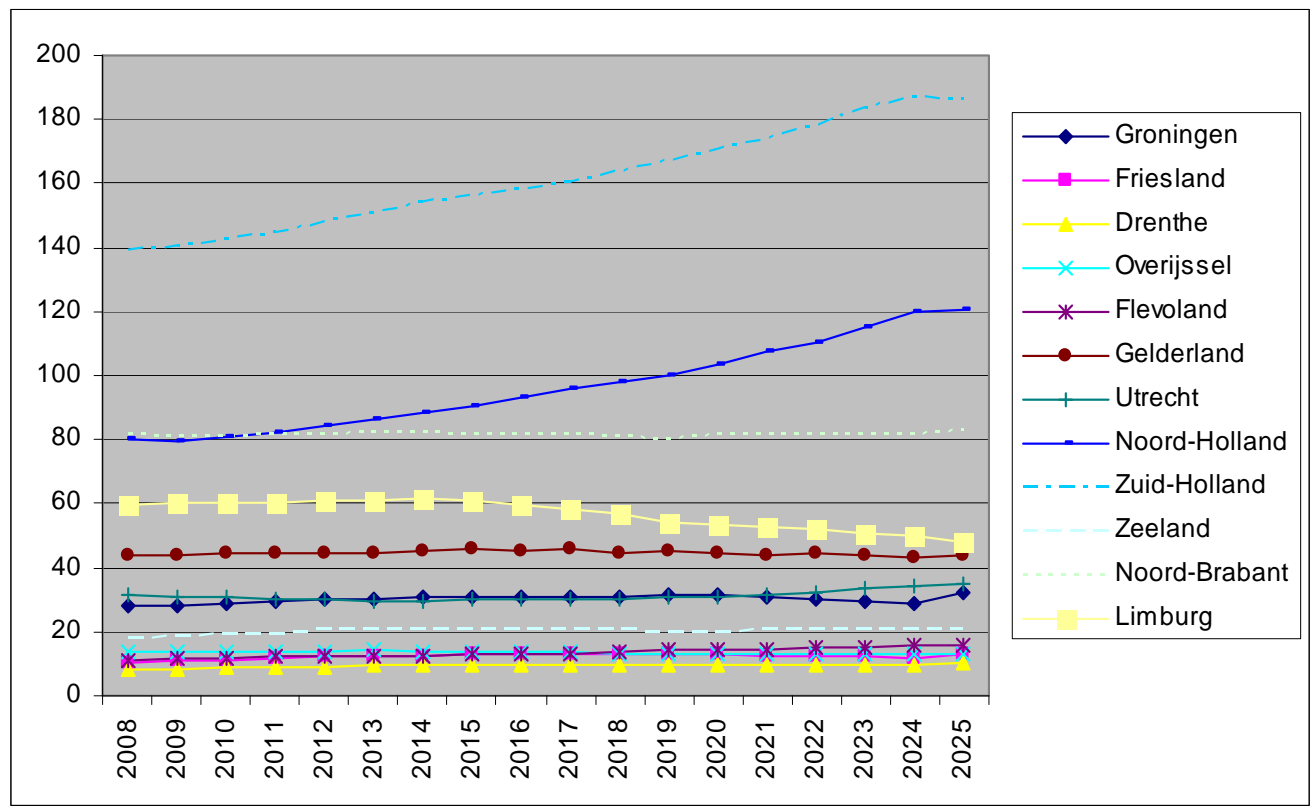

Figuur II.16

Relatief aantal afgestudeerde westerse allochtone mannen hbo techniek, 2008-2025 (geïndexeerd op 2008=100)

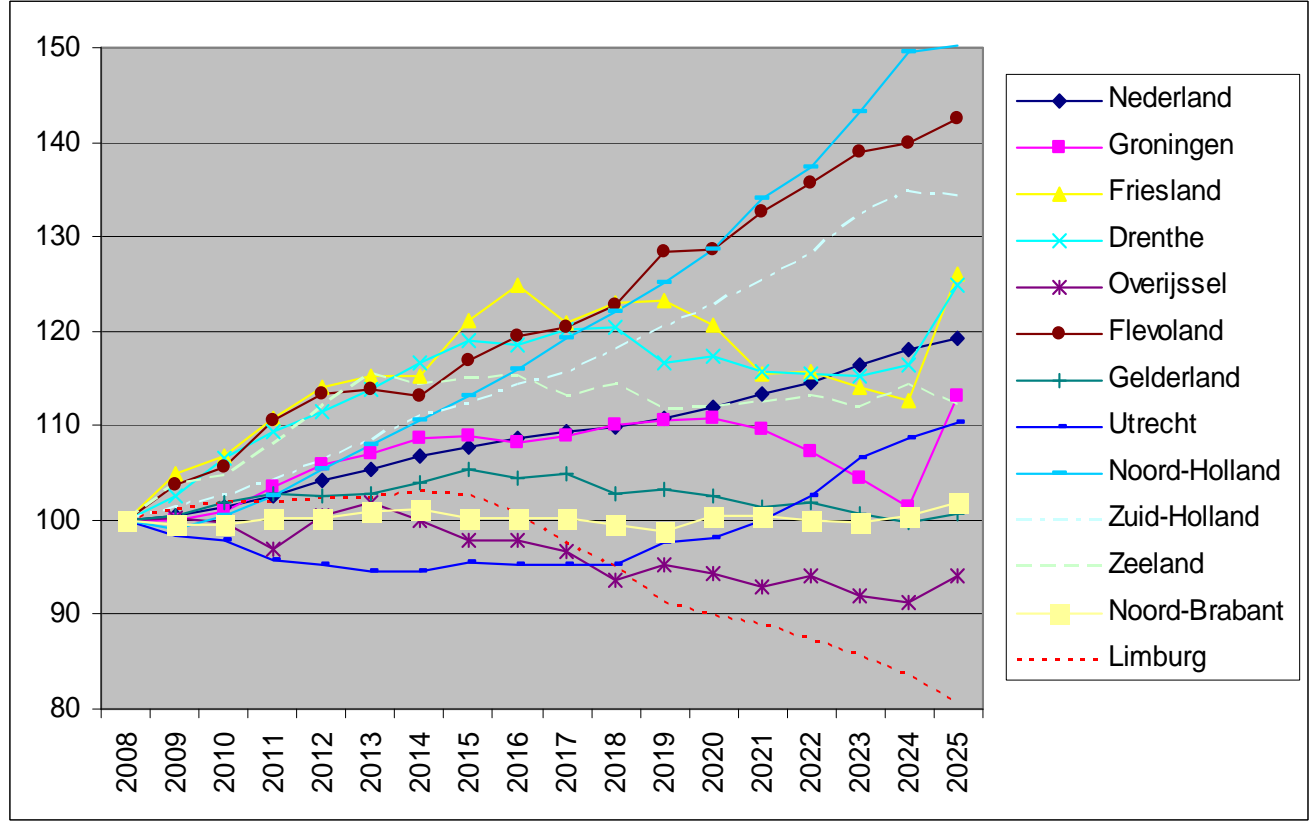


Figuur II.17

Absoluut aantal afgestudeerde niet-westerse allochtone mannen hbo techniek, 2008-2025

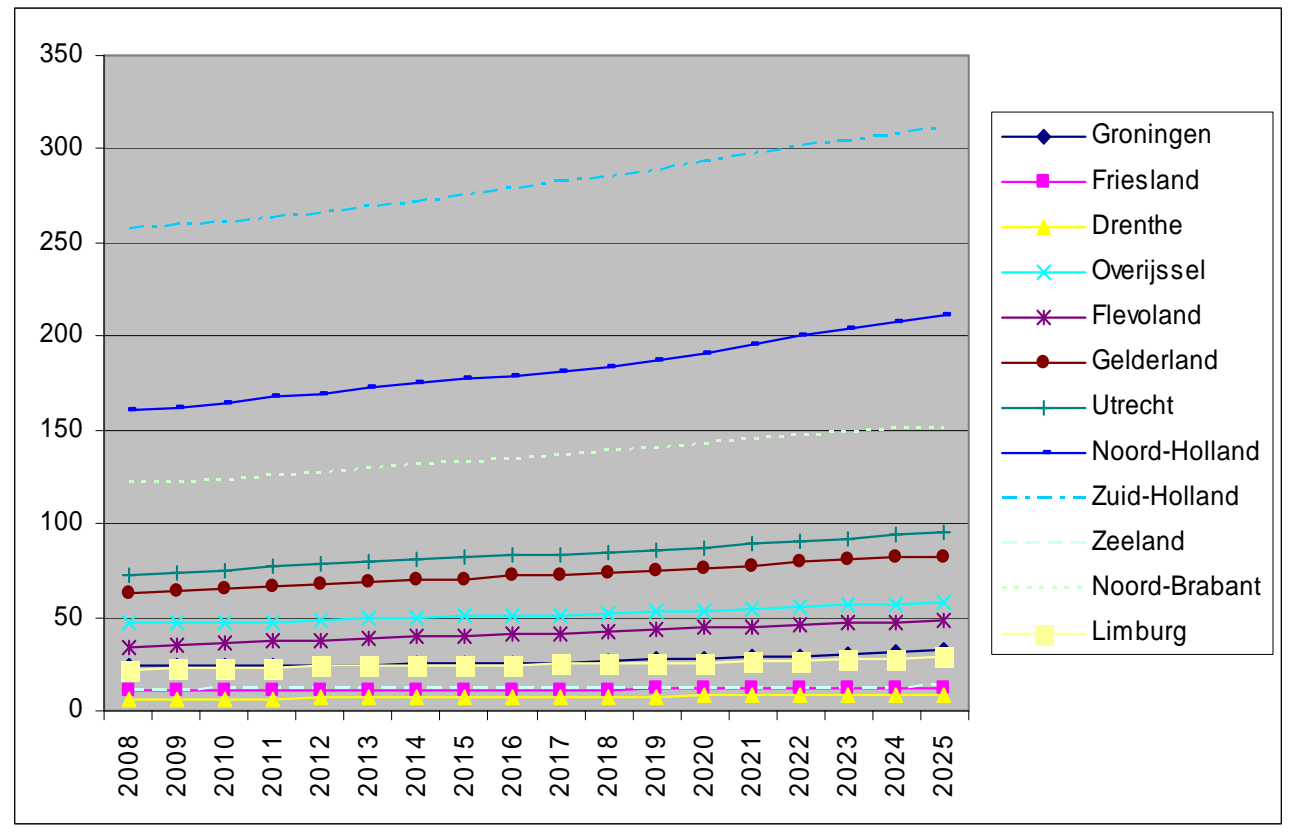

Figuur II.18

Relatief aantal afgestudeerde niet-westerse allochtone mannen hbo techniek, 2008-2025 (geïndexeerd op 2008=100)

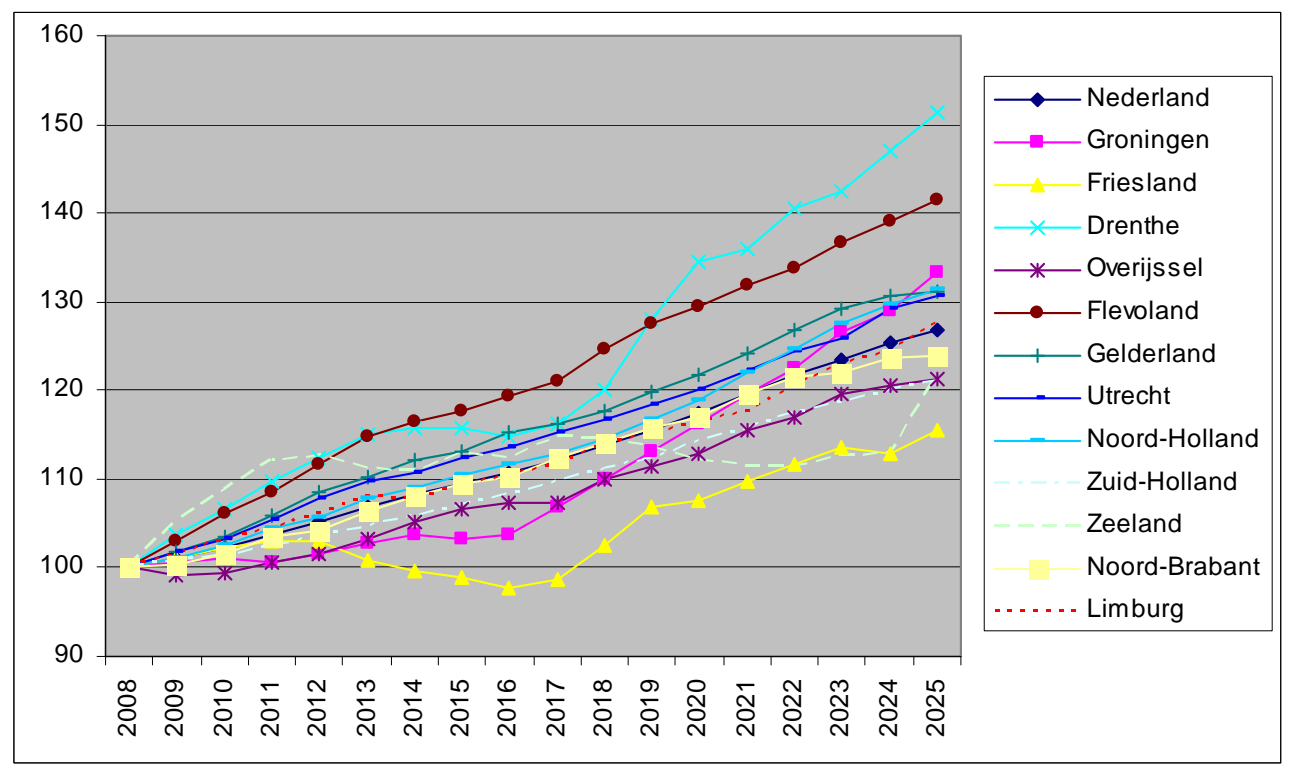


Figuur II.19

Absoluut aantal afgestudeerde autochtone vrouwen hbo techniek, 2008-2025

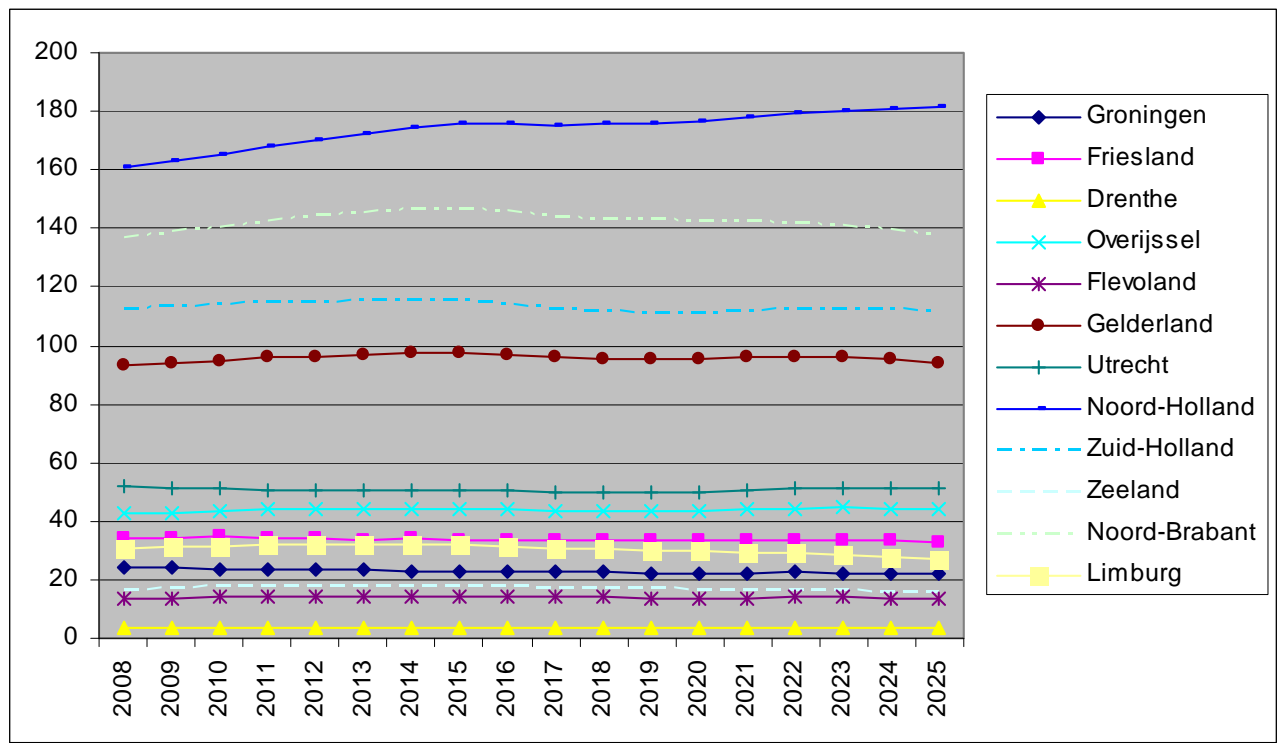

Figuur II.20

Relatief aantal afgestudeerde autochtone vrouwen hbo techniek, 2008-2025 (2008=100)

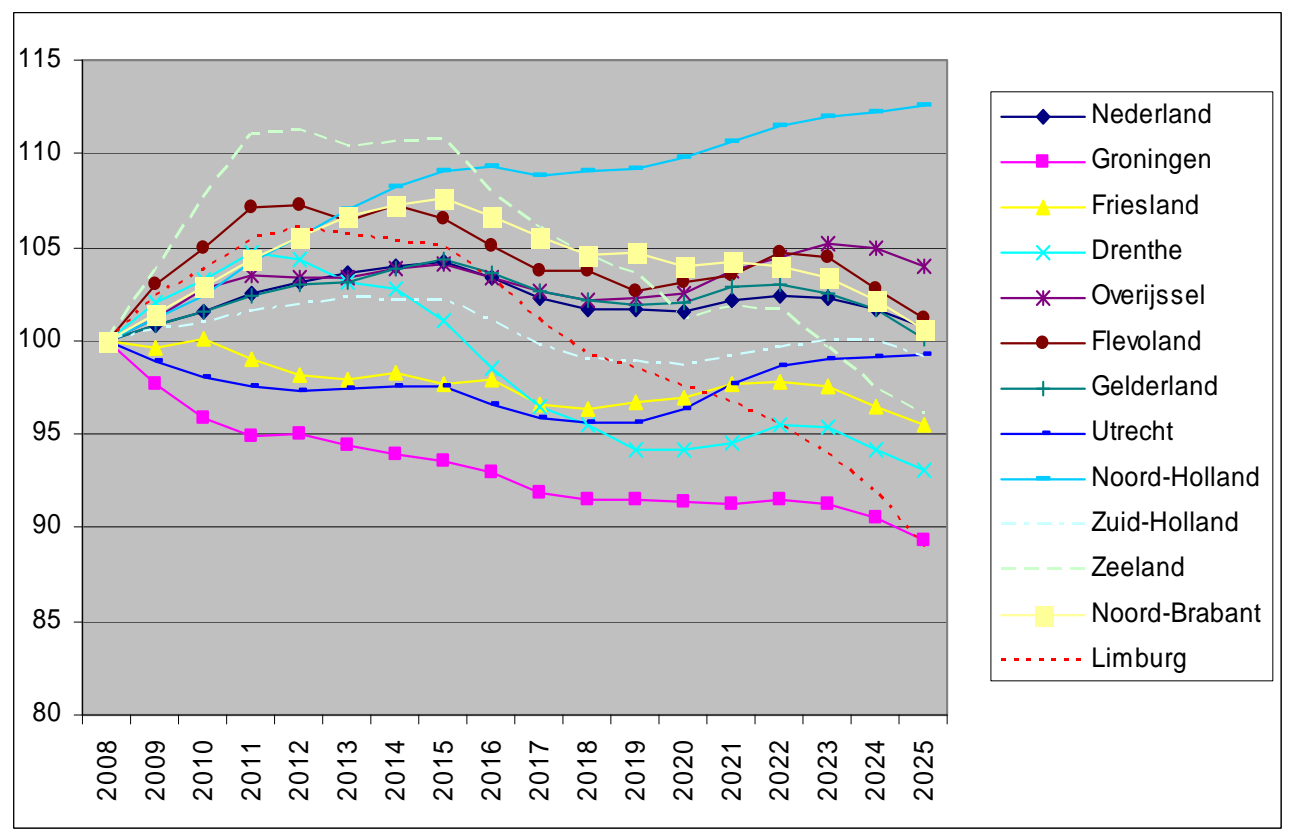


Figuur II.21

Absoluut aantal afgestudeerde westerse allochtone vrouwen hbo techniek, 2008-2025

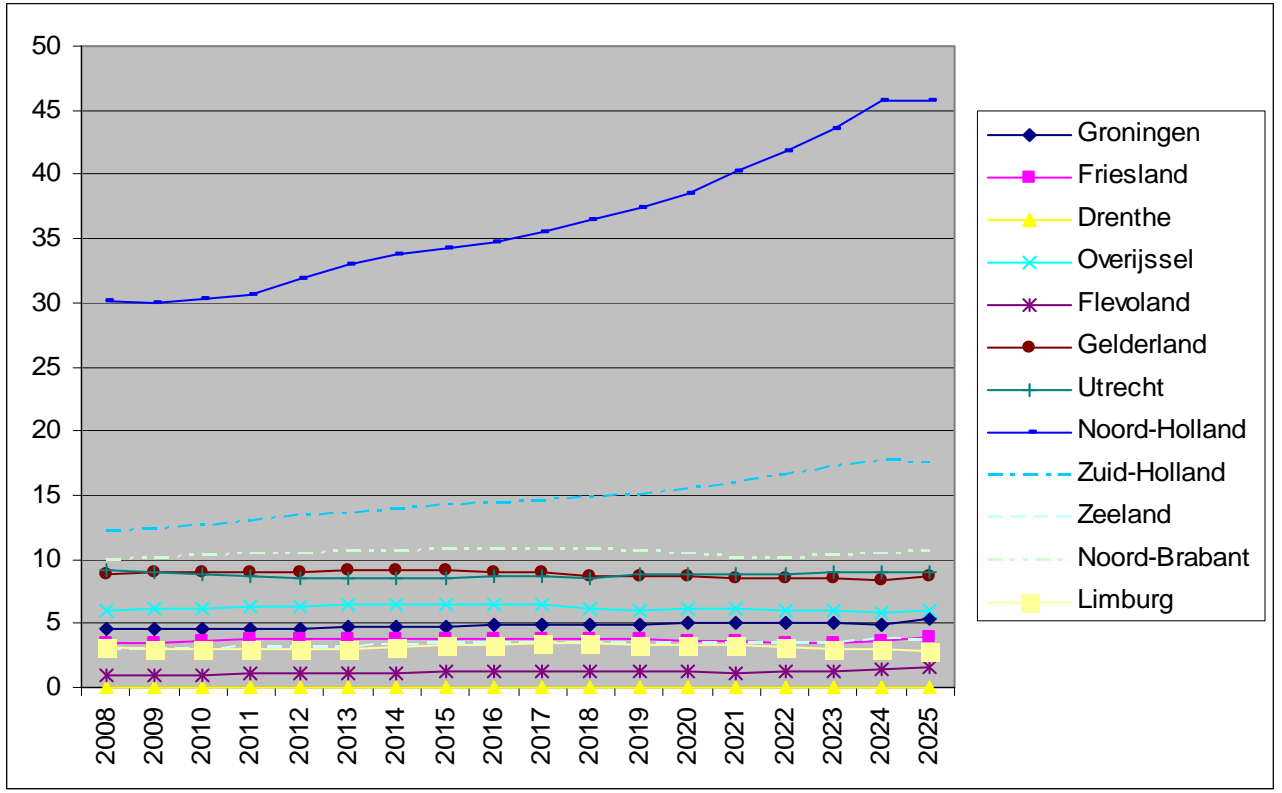

Figuur II.22

Relatief aantal afgestudeerde westerse allochtone vrouwen hbo techniek, 2008-2025 (geïndexeerd op 2008=100)

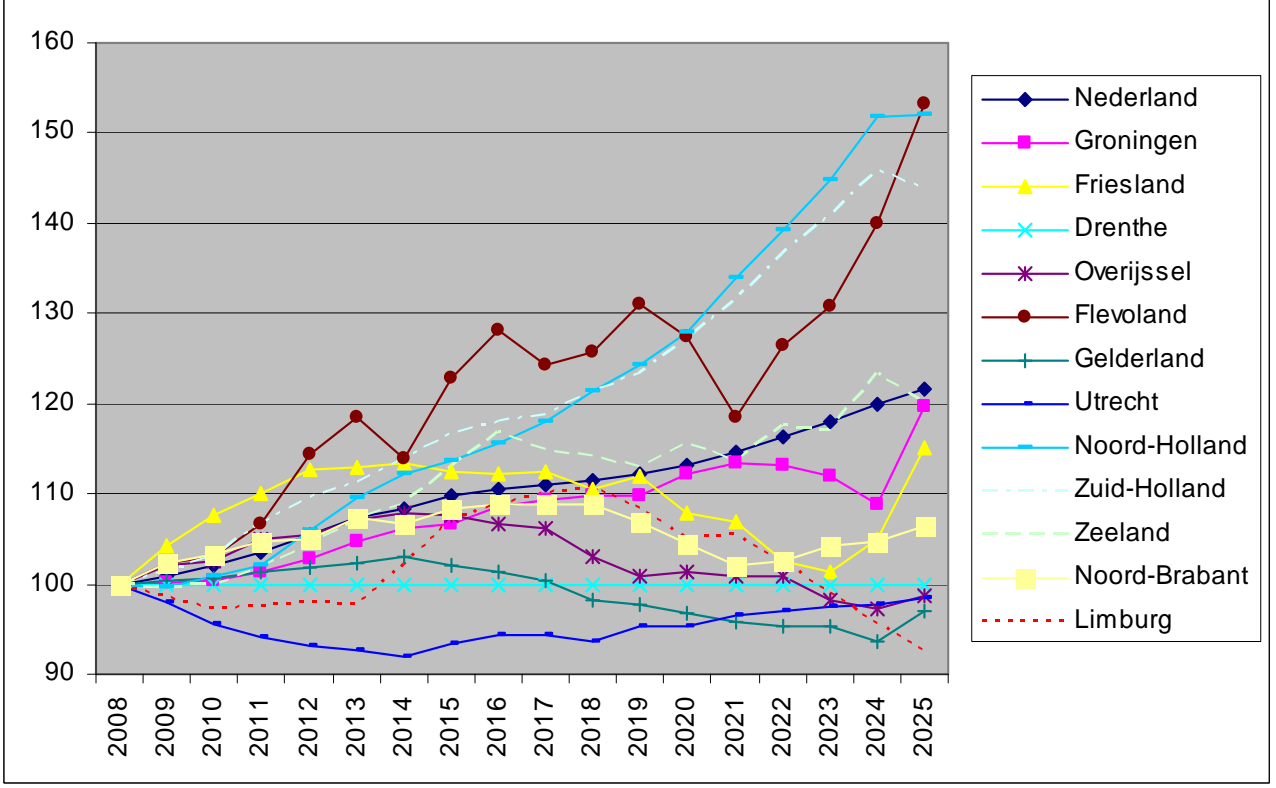


Figuur II.23

Absoluut aantal afgestudeerde niet-westerse allochtone vrouwen hbo techniek, 2008-2025

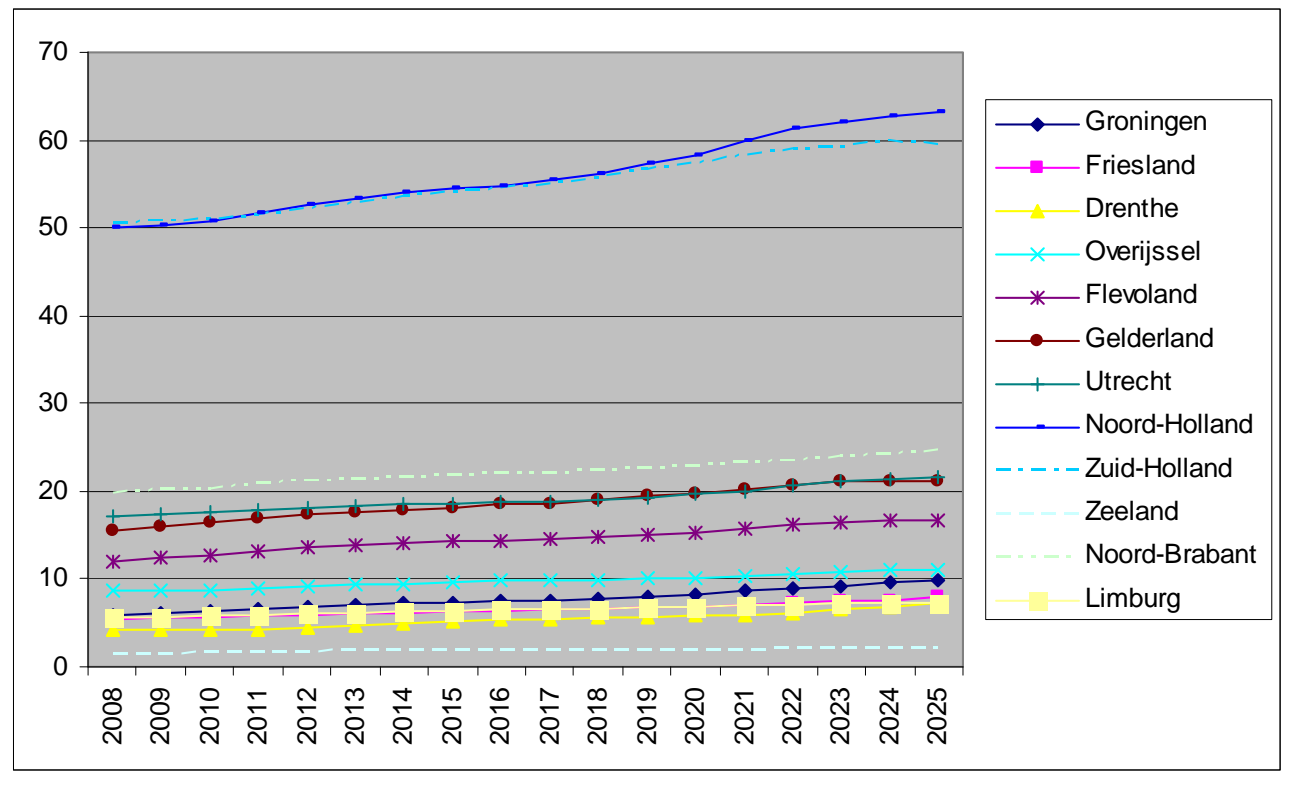

Figuur II.24

Relatief aantal afgestudeerde niet-westerse allochtone vrouwen hbo techniek, 2008-2025 (geïndexeerd op 2008=100)

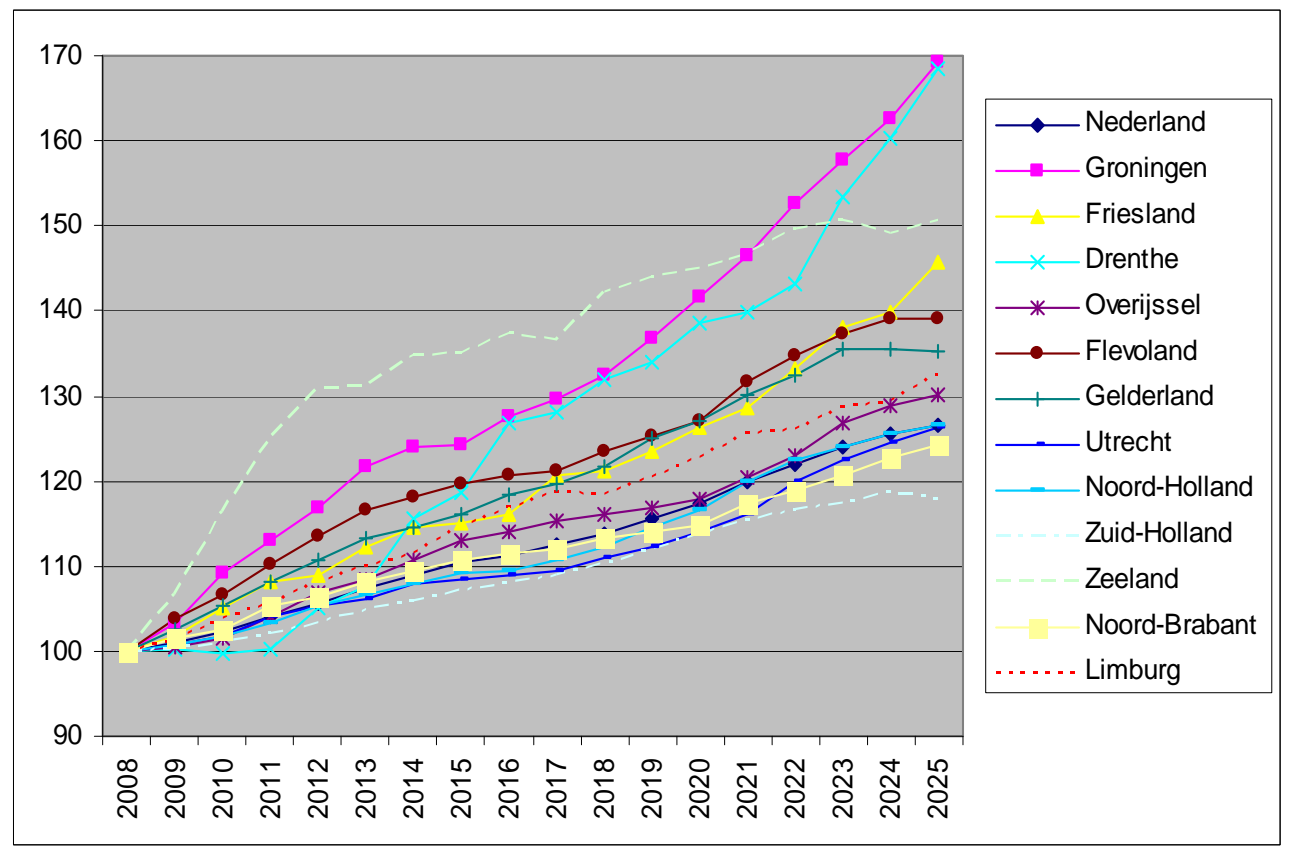




\section{Wo}

Figuur II.25

Absoluut aantal afgestudeerde autochtone mannen wo techniek, 2008-2025

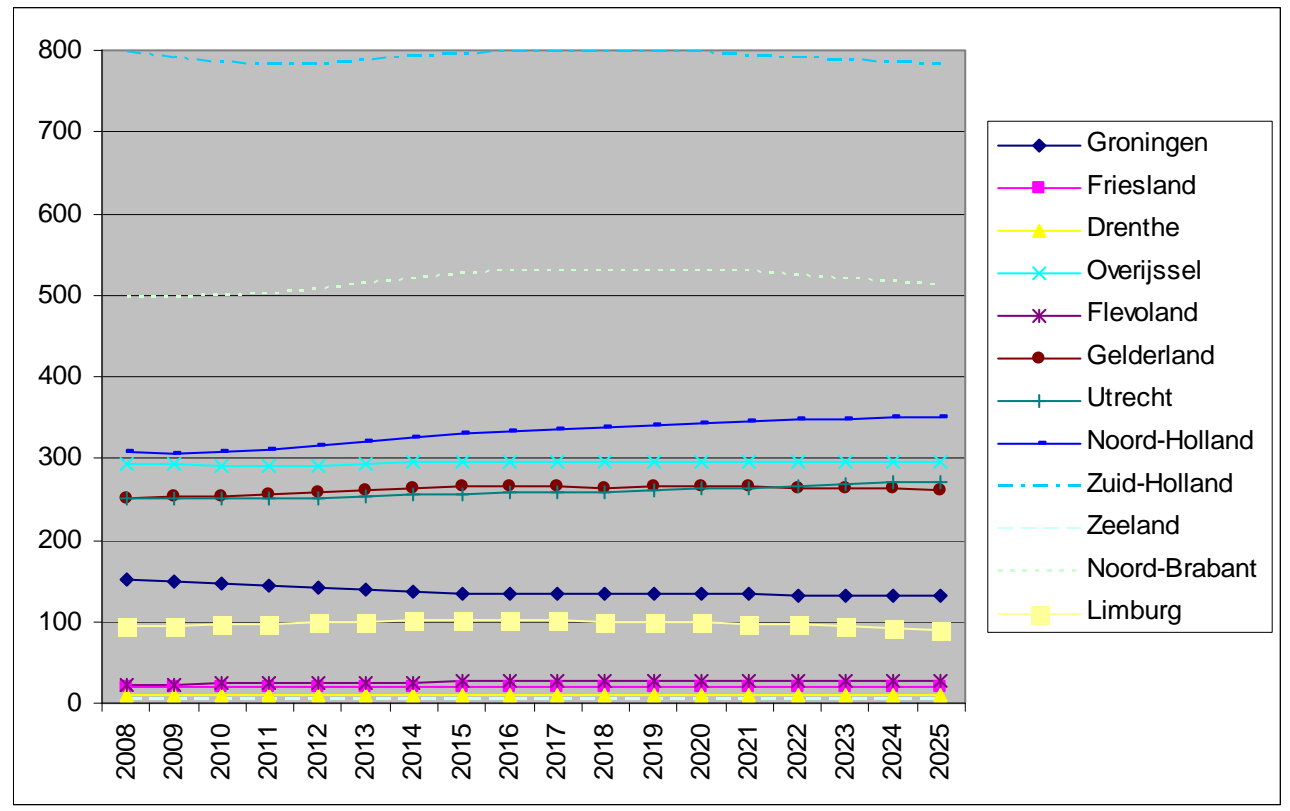

Figuur II.26

Relatief aantal afgestudeerde autochtone mannen wo techniek, 2008-2025 (geïndexeerd op 2008=100)

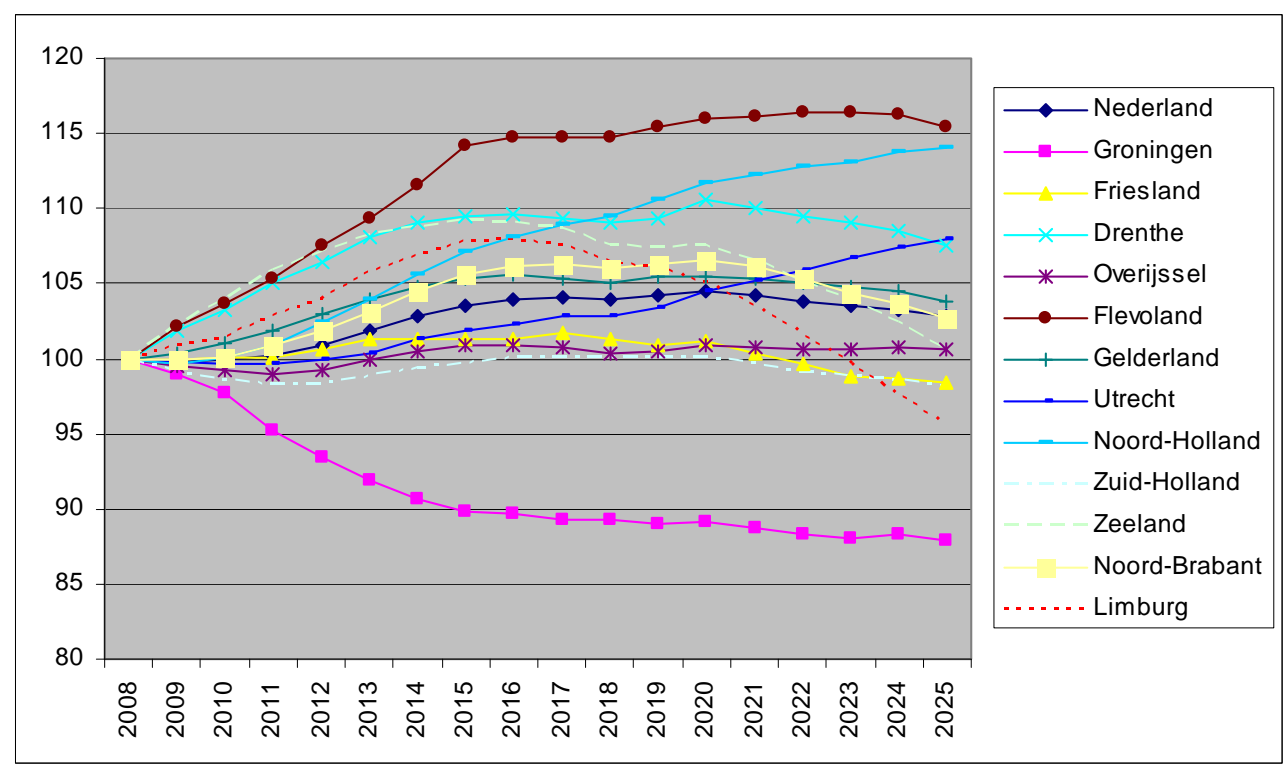


Figuur II.27

Absoluut aantal afgestudeerde westerse allochtone mannen wo techniek, 2008-2025

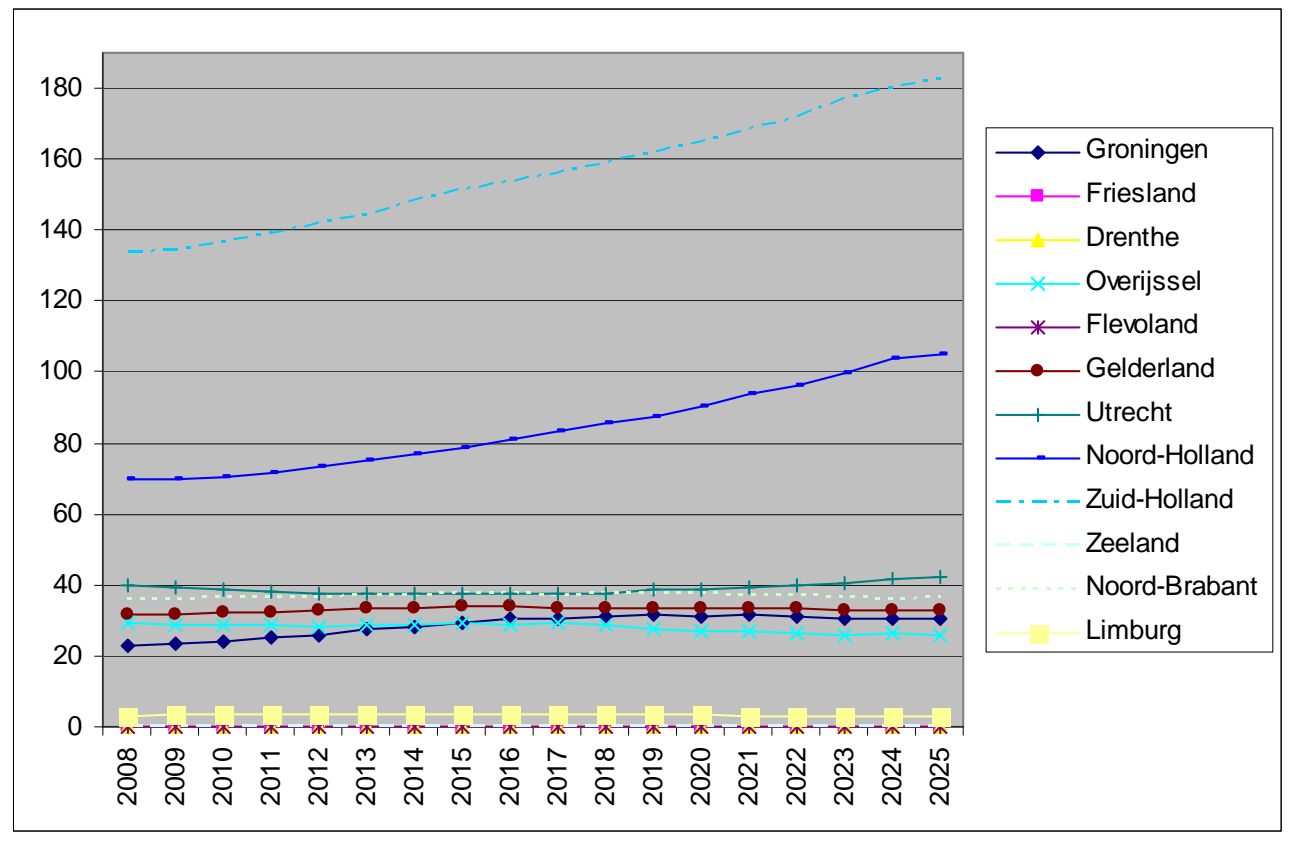

Figuur II.28

Relatief aantal afgestudeerde westerse allochtone mannen wo techniek, 2008-2025 (geïndexeerd op 2008=100)

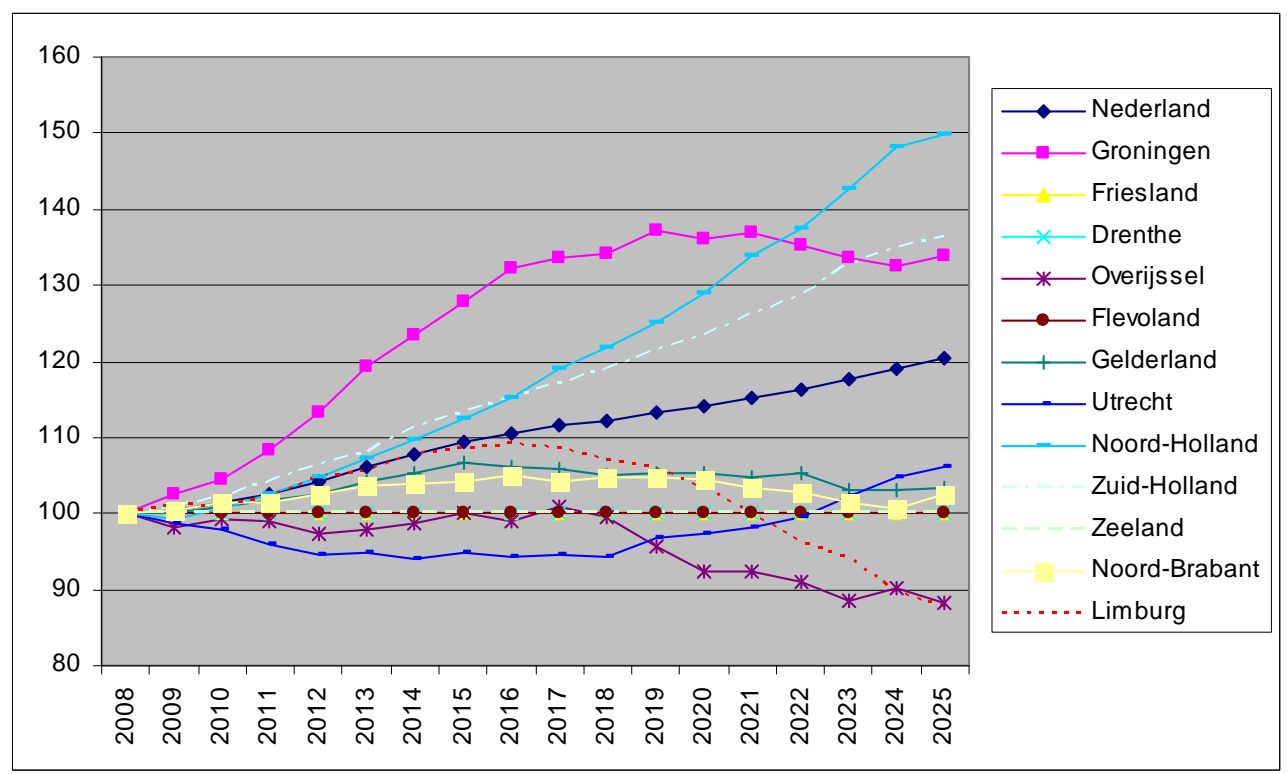


Figuur II.29

Absoluut aantal afgestudeerde niet-westerse allochtone mannen wo techniek, 2008-2025

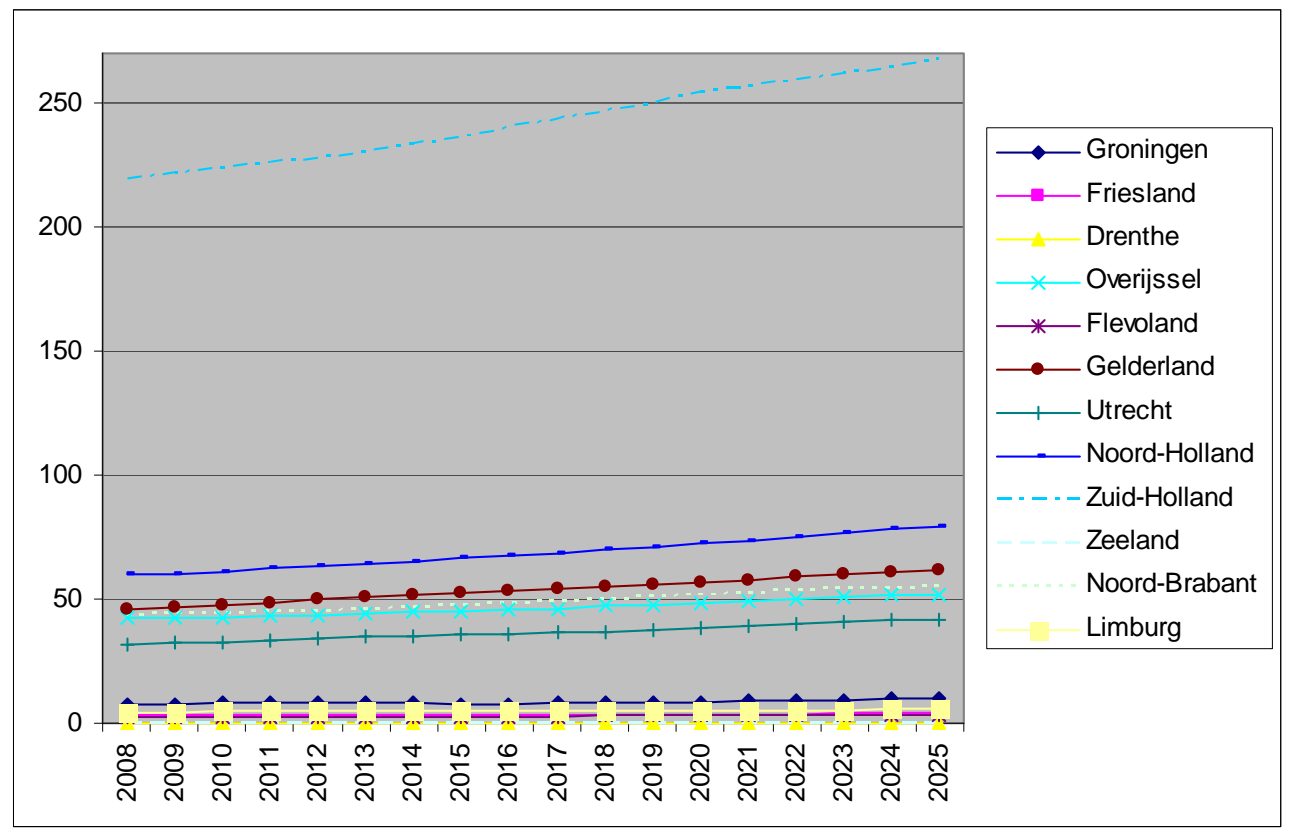

Figuur II.30

Relatief aantal afgestudeerde niet-westerse allochtone mannen wo techniek, 2008-2025 (geïndexeerd op 2008=100)

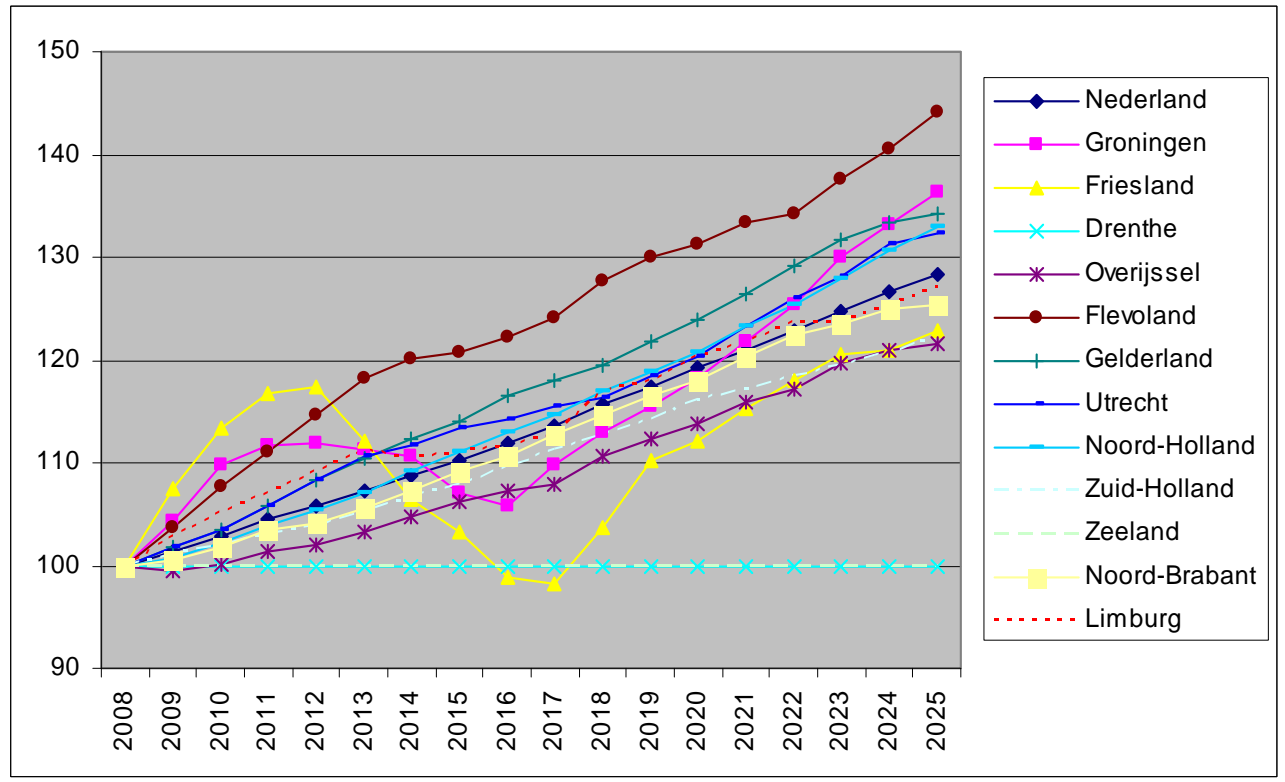


Figuur II.31

Absoluut aantal afgestudeerde autochtone vrouwen wo techniek, 2008-2025

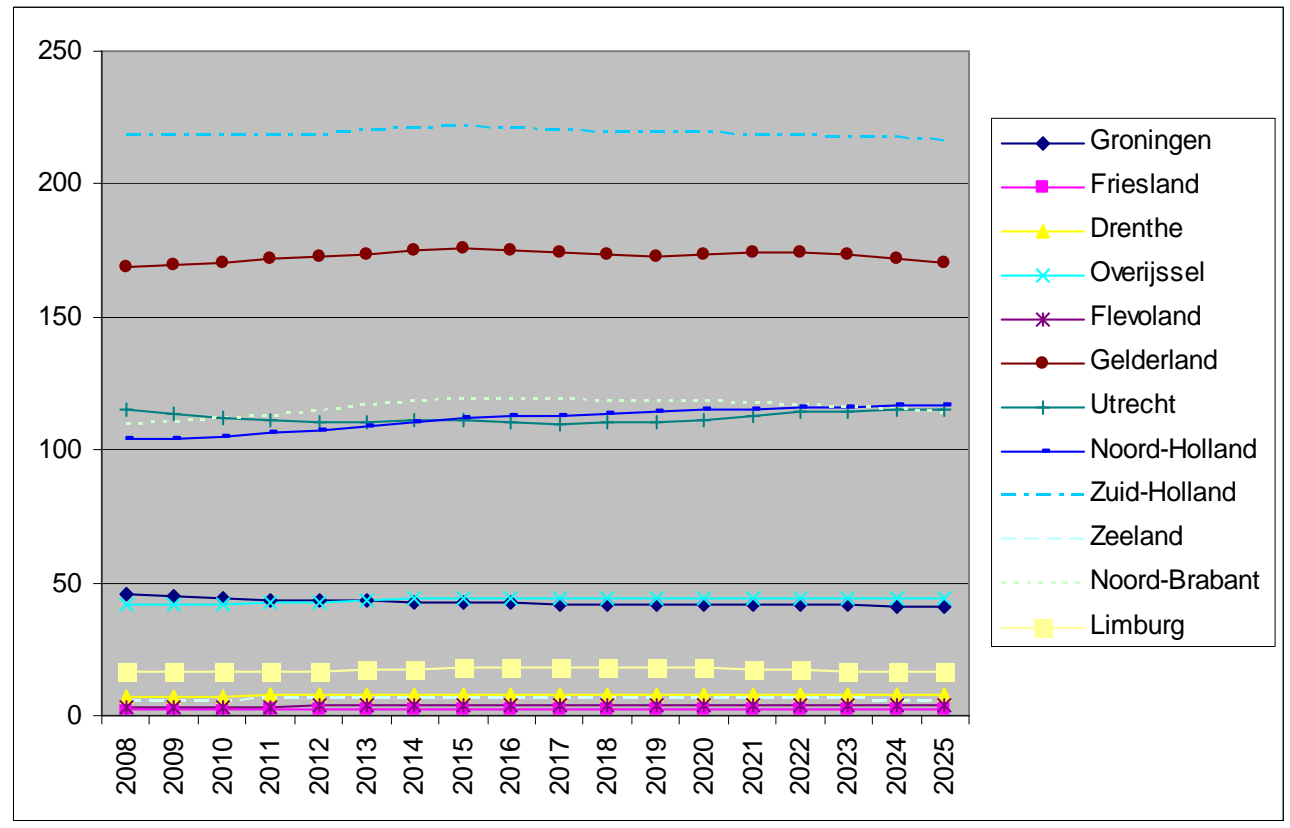

Figuur II.32

Relatief aantal afgestudeerde autochtone vrouwen wo techniek, 2008-2025 (geïndexeerd op 2008=100)

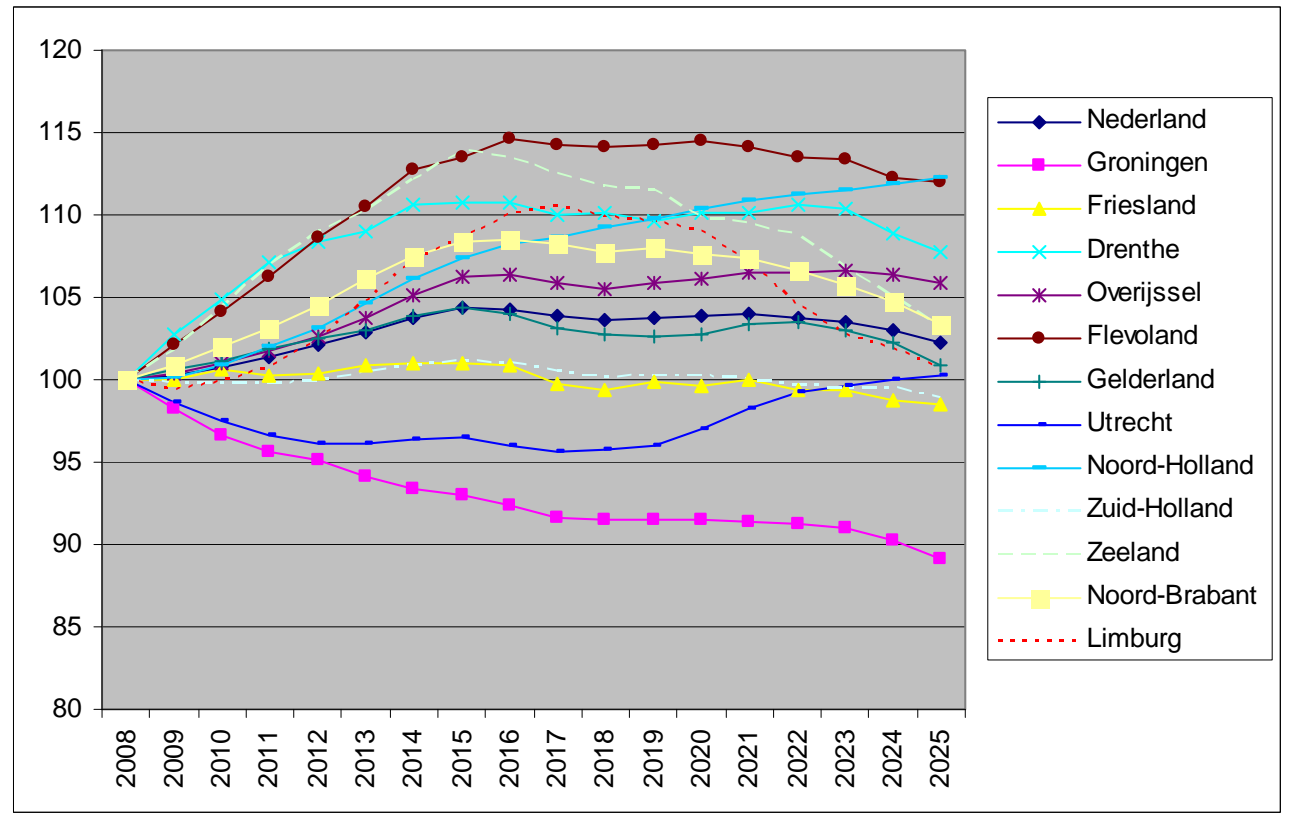


Figuur II.33

Absoluut aantal afgestudeerde westerse allochtone vrouwen wo techniek, 2008-2025

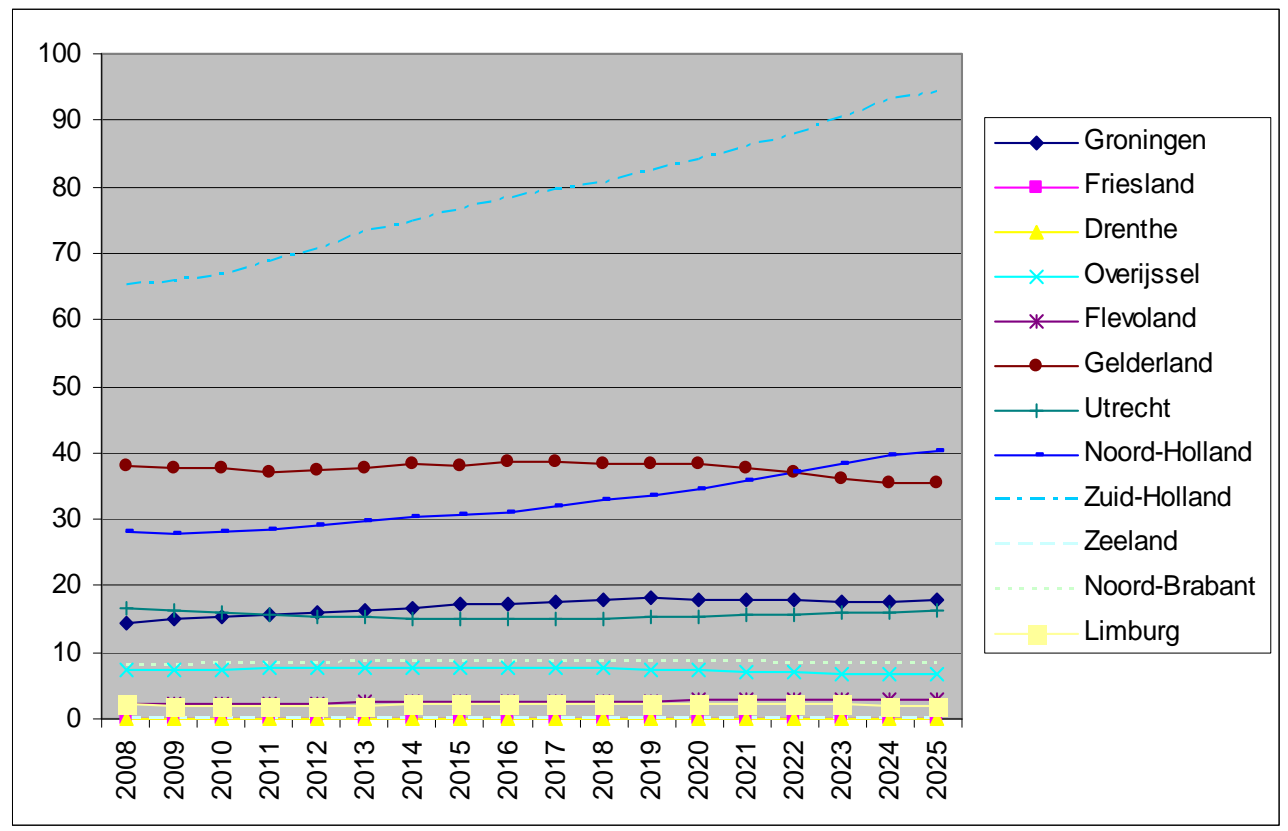

Figuur II.34

Relatief aantal afgestudeerde westerse allochtone vrouwen wo techniek, 2008-2025 (geïndexeerd op 2008=100)

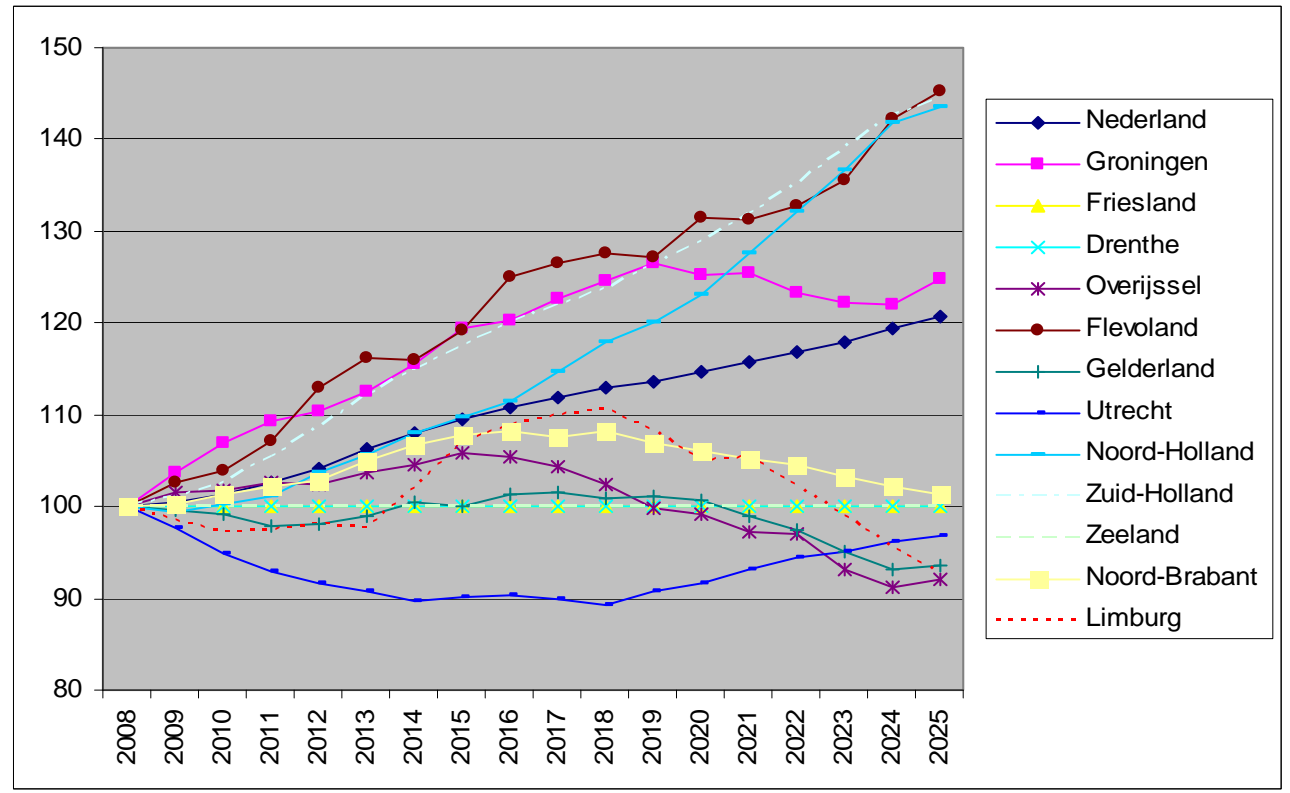


Figuur II.35

Absoluut aantal afgestudeerde niet-westerse allochtone vrouwen wo techniek, 2008-2025

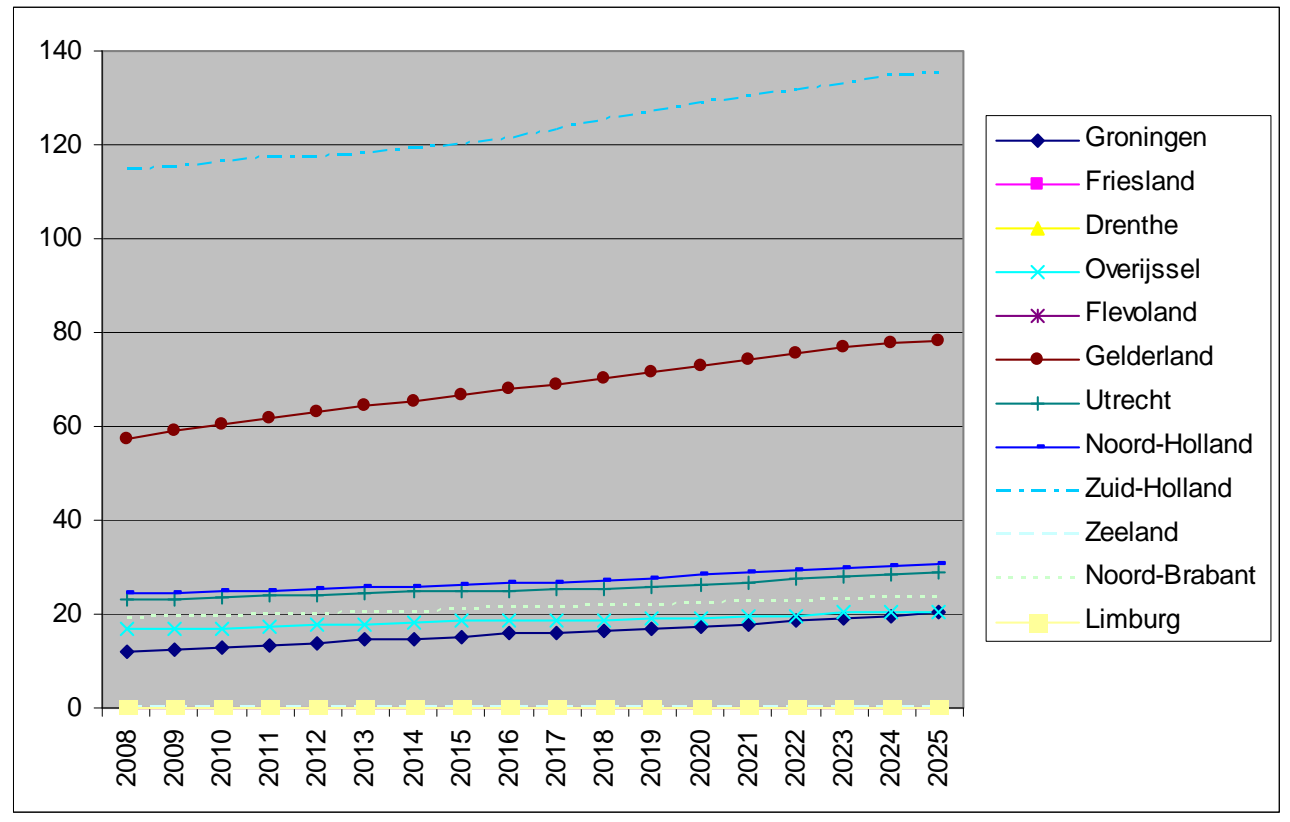

Figuur II.36

Relatief aantal afgestudeerde niet-westerse allochtone vrouwen wo techniek, 2008-2025 (geïndexeerd op 2008=100)

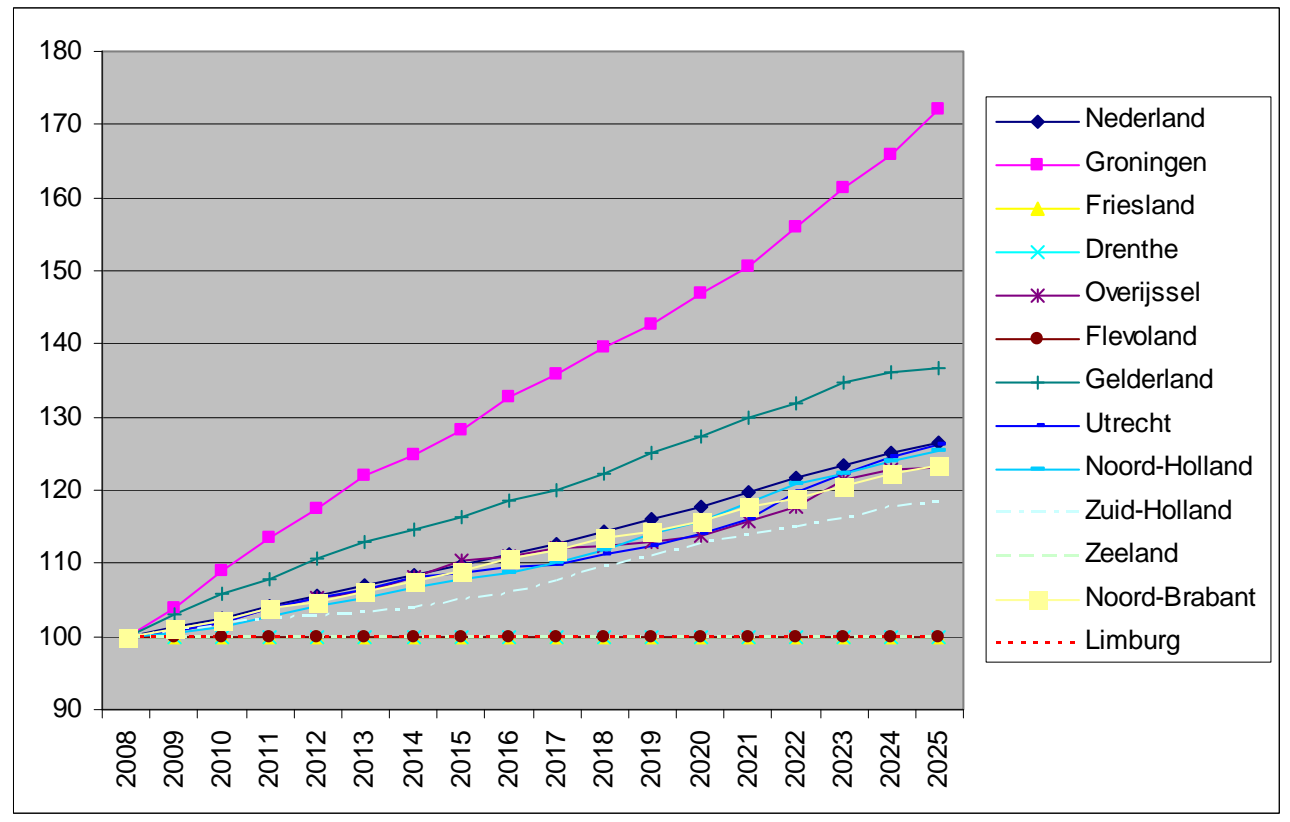

